1919 Se 8 



\section{THE GENUS OPISTHORCHIS}

BY

ARSHAG KILLIJIAN SEUERIAN

A. B. Ripon College, 1918

THESIS

Submitted in Partial Fulfillment of the Requirements for the

Degree of

MASTER OF ARTS

IN ZOOLOGY

IN

THE GRADUATE SCHOOL

OF THE

\section{UNIVERSITY OF ILLINOIS}





\section{UNIVERSITY OF ILLINOIS}

THE GRADUATE SCHOOL

June 13 1919

I HEREBY RECOMMEND THAT THE THESIS PREPARED UNDER MY SUPERVISION BY_Arahag Killijian Severian ENTITLED___. The Genua Opisthorchis

BE ACCEPTED AS FULFILLING THIS PART OF THE REQUIREMENTS FOR THE DEGREE OF Master of Arts

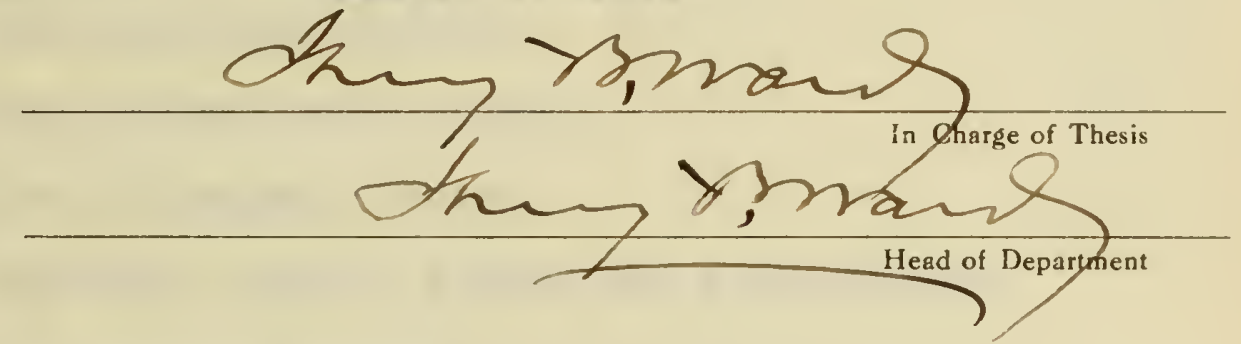

Recommendation concurred in*

Committee

on

Final Examination*

*Required for doctor's degree but not for master's 

TABEE OF CONTENTS

I. Introduction

II. History

III. Synopsia of the species once named in the genus OpddhorchiB; and there diviaion into three Genera:

Dpisthorchis, Amphimerus and the genus Parapisthorchis

IE. Discussion

v. Description of Opisthorchis vivarrini Var.Chisngmai

1. Material and Technique

2. Hitotory

3. General description of the form

4. The excretory system

5. The reproductive system

6. The alinentays oystem.

7. The body layers, glands and parenchyms

8. The nervous system

9. Discussion.

VI. Bibllography

VII. Explanation of Plates 



\section{INTRODUCTION}

This investigation has been carried on under the direction of Dr. H. B. Ward with material furnished by him. The bottle containing the material wa labeled oplathorchis viverrini (?D). The epeoimens were collected in 1915 by Dr. C. W. Mason from the liver of a prisoner who died in the Chiengmal jail, Siam. Hundreda of theve forms were sent to Dr. Ward.

Leiper 1915 made a provisional diagnosis of this form and called it Opisthorchis viverrini.

The object of the proaent paper is two-fold: firat to give a detalled description of this form; second, to bring all data available on the genus opisthorchis in a single work for a ready reference in the atudy of the problem of speales and varieties among the closely related specios now existing.

Technique. - The opecimens were somewhat poorly preserved. The material was stained in to to th th Erlich's acid hematoxylin, borax carmine, and fuchsin. Cross, frontal and sagittel sections were made and stained with dilute Delafield'a bematoxylin and with Erlich's acid hematoxylin countored stained with eosin. A great number of apecimens were examined for marked variations. Twenty specimens were however selected at random for general measurements. 
Digitized by the Internet Archive in 2013

http://archive.org/details/genusopisthorchi00seue 


\section{HISTORY}

LOOBв (1899) made a few genera out of various species classified under the genus Opisthorchis. He placed these genera (Holometra, Metorchis, Clonorchis and Opisthorchis) under the subfamily Opiathorchilnae. The specific diagnoals of thio nom subfamily Opiothorohinae Looss (1899:563) is as follows:

Fasciolidae of medium size with a alender elongated body, anterior end noticeably tapering. Suckers near one another and usually not well developed. Pharynx present. Intestinal crura long and Bimple, short and slender oesophagus. Exoretory bladder Y-shaped with a long S-shaped branch winding between the testes and with short aide branches. Genital pore commonly in front of the acetabulum. Copulation organs absent. Testes near the hinder end more or less obliquely placed. Overy is in front of the tes tes. Laurer's canal present. Seminal receptacle very strongly developod. Uterus loops in front of the testes. Viteliaria moderately developed, lateral to the intestinal orura.

Found in the liver of mammals, birds and reptiles.

The above diagnosis and the three new genera belonging to the new subfamily, in its modified form has been accepted by all parasitologiats.

Campula was originally proposed for distomes with a wavy intestine by Cobbold (1885). Stiles and Hassall did not find auficient ground for the separation. "Oplsthorchis was based upon the topography of the genital organs, Campula upon the crooked intestine. The two genera are, however, hardly to be separated at present, since Campula agrees in topography with opiothorchis 

$+$

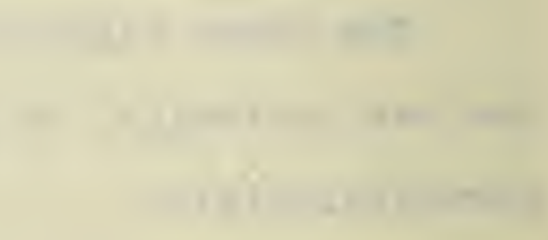


(Paras. 1:85). Later Cobbold himself admitted the 1dentity of the two species ( $885: 39$ ). Looss expresses the same opinion as Stiles and Haseall (1889)

Key to the genera of the subfamily Opisthorchiinae Looss(1899)

1. (2) Vitellaria lateral to intestinal crura - . - 3

2. (5) Vitellaria anterior to intestinal crura, lateral to oesophagus; uterine coile fill entire body postexior to acetabulurn ….... HOLOMETRA

3. (2) Vitellaria not extending anteriorly beycnd the acetrbulum - . . . . . . . . 4

4. Vitellaria extending beyond the acetabulum --

- - METORCHIS

5. (6) Teates dendritic . . . . . . . . .

6. Testes not dendritic . . . . . - OPISTHORCHIS

7. Testes dindritic $\ldots \ldots \ldots$ CLONORCHIS

The diagnosis of the genus Opisthorchis Blanchard and the modifications made by Looss are placed below for comarison.

Opisthorchis R. Blanchard (1895:217). - Medium and lerge forma. Oesophagus long or short, occasionally wanting. Intestinal branches not ramified. Genital orifice in front of acetabulum. No clrrus pouch. Viteline glands generally do not extend behind the testes. Ovary situated posterior to uterine coils. Testes simple, globular and ramified.

Genus Opisthorchis Blanchard in partim.- Body treneparent, often very strongly attenuated, posterior end bread; tapering toward the anterior end. Skin smooth with or without spines. 

Testes more or less strongly lobed or ramified, lie obliquely one in front of the other. Ovary lobed or simple. Uterus loops lying in front of the ovary and not usually reaching out over the intestinal crura. Vitellaria does not extend forward beyond the ventral acetabulum.

The type of the genus is Opisthorchis felineus.

From the above diagnosia of the genue ojiathorchis I leave out opecies once reported as Opiathorchis which do not agree to the modified genus Opisthorchis. For example D. albidu Braun (1893), accoraing to the later modification of opiothorchio Blenchard, falls into the genur Metorchis Looss (1899). 0. exigua Muhl. (1898) comes under Holometra. 0. sinensis Cobbold (1815) under Clonorchis. In the genus Metorchis are 0 . craseluscuia Rud.1809 var. ( $?=$ gp. nov. ? ) Janus. O. crassiuscula janus Kowel. (1898h), 0. craseiuscula Looss (1899b:678), 0. xanthosome Crepl? Wag., var. (?) campascua.

The speoies belonging to the genus opisthorchis at prosent are as followa:

0. Pelinius Riv. 1884

- 0 . tenuicolils Rud. 1819

0. viverrini Poirier 1886

0 . longisstmus Linst. 1883

0. simulans Loose 1896

0. geminus Looss 1896

0. piscicola Odhner 1902

0 . obsequens $\mathrm{N} 1 \mathrm{col} 11915$

0. entrd . Ratz 1900 

0. interrurtus Braun 1901

- Iancea Diesing 1850

0. noverca Braun 1902

0. pseudofel1naus Ward 1895

0 . Bpolosus St1LeB and Hassall 1896

0. ovalif Barker 1911

O. caninu Barker 1911 

III. SYHOPSIS OF THE SPECIES ONCE NAMED IN THE GENUS OPISTHORCHIS: AND THERE DIVISION INTO THREE GENERA: CPISTHORCHIS; AMPHIMERUS; AND PARAPISTHORCHIS:

(Ward 1903 and Stephen 1916)

The type species designated for the genus Opisthorchis is 0. Lelineus Rivolta (1884). Gurlt named the Pluke Distoma conus in 1831, but Creplin had already used the name for another apecies in 1825. Von Siebold's Distoma lanceolatum 1836, was preoooupled by the genus known as Dicrocoelium dendriticum. Distome sibirioum proposed by Winogradoff 1892 cannot be accepted by law of pricrity and in fact it is a variety of 0 . felineus Riv. Rivolte gave D. felineus in 1884 which holds. D. tenulcolle, Mahl. 1896.

Diagnosis - Body much Ilettened, yellowish in color and almost transparent in $11 \mathrm{ving}$ specimens. The sides of the body are paralled eate in the region anterior to the acetebulum which is conical. There is a shallow conetriction at the level of the ventral sucker noticeable in fresh and contracted specimens. The posterior end is elther pointed or rounded off. The length and breadth vary according to the contraction, being uaulily 8 to $11 \mathrm{~mm}$ by 1.5 to $2 \mathrm{~mm}$. The suckers are about one-fifth to ons-sixth of the body length diatant from each other, and about equal in size, 0.23 to $0.25 \mathrm{~mm}$. The oesophagus is very short. The intestinal crura reach almost to the posterior border and are often filled with blood. The excretory pore is at the posterior extremity, and the excretory bladder forks in front of the anterior teatis. Anterior teatis four lobed, postericr five lobed, and occupy the posterior fourth of the body one placed obliquely in front of the other. Ovary median, transverse, simple or olightly lobed. 

Smaller than the pear or retort-shaped receptaculum seminal is. Laurer's canal present. Uterus in the median field and entirely within the intestinal crura. The vitellaria occupy the fairly broad lateral areas in about the centrel third of the body, beginning behind the ventral sucker and terminating at about ho level of the ovary. The acinis are amall and are arranged in groups of seven to eight, separated by interstices. The genital poro is immediately preacotabular. Egga oval with distincloperculum at the pointed pole, 0.030 by $0.011 \mathrm{~mm}$.

Habitat - Gall duct and gall bladder of cats, dogs, glutton, fox and man.

Distribution - Europe, (Germany, France, Holland, Scandinavia, Hungary and Russia) and Siberia.

\section{Opisthorchis viverrini Poirier 1886}

Body transparent, lanceolate, $6 \mathrm{~mm}$ long and $2 \mathrm{~mm}$ broad. The dorsal surface a little concave the ventral aurface flat. Suckers small and equal in size, $0.23 \mathrm{~mm}$. Ventral sucker at the beginning of the anterior third. The distance between the two suckers $1.8 \mathrm{~mm}$. Genital orifice immediately above the ventral sucker. The length of the pharynz $0.1 \mathrm{~mm}$ immediately posterios to the oral sucker, which has wide opening. Desophagus is relatively short $0.3 \mathrm{~mm}$. The intestinal forks are simple and with a nearly constant deameter $0.1 \mathrm{~mm}$ and terminate blindly at the extreme posterior end.

The ovary is situated in front of the tester and 1s multilobed. It extends transversely, having wo well developed lobes on the left and two amaller oner on the right. The shell glands in this case present a peculiar aspect. They are not compact 


\section{.}

1

+1

t.

$+\frac{1}{2}$

1.

$\sqrt{2}+x^{2}$

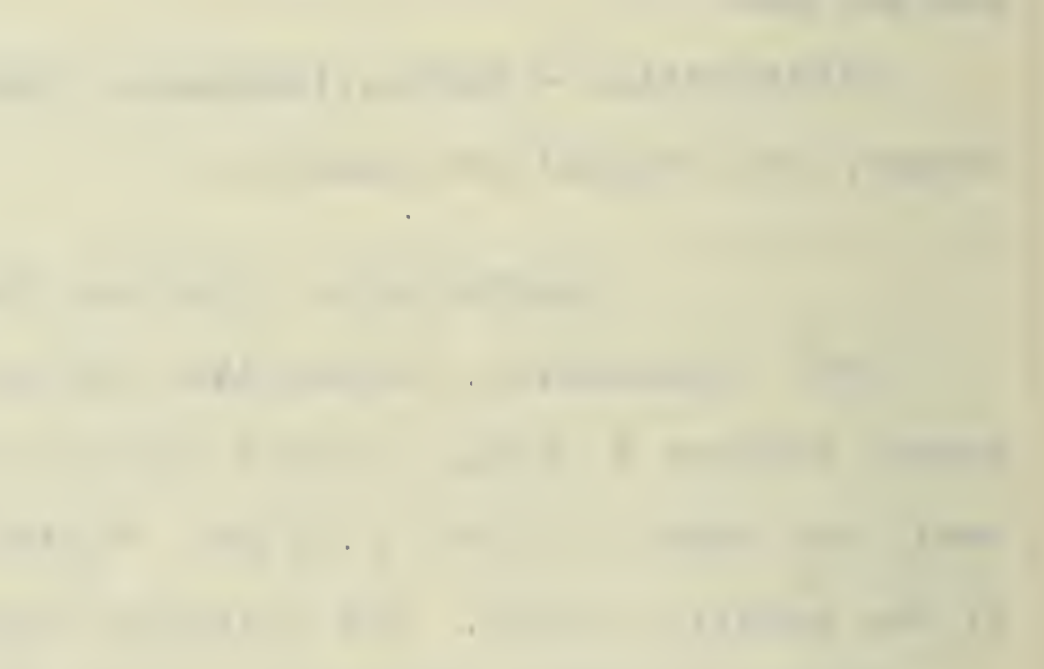

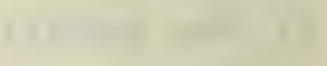

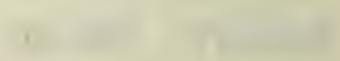

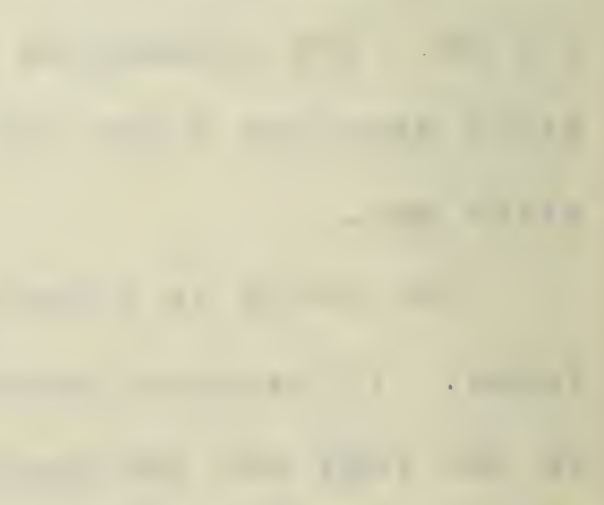


but small unicellular isolated glands scattered in the parinohyme around the beginning of the uterus.

The racemose iteline glands are situated laterally in the median region of the body and in front thoy dissappear before reaching the level of the ventrel sucker. The aingle trangverse vitelline duct has the viteline reservoir on the left of the shell gland. Laurer's canal very distinct at the base of which the pear shaped receptaculum seminalis is situated just outsice of the sheil gland. The uterus is very strongly colled and aituated in the region of the body between the ventral sucker and the ovary.

The egga are small, ovold, $0.026 \mathrm{~mm}$ long and $0.013 \mathrm{~mm}$ wide.

The male organs are composed of two small four lobed testes; which aro situated at the posterior of the body. The vas defeners 1s a very narrow and long duct. It forms a coiled pouch at the right of the middle line of the body and extends to the genital cloaca.

The excretory apparatus is not clearly distinguished. The excretory bladder is quite voluminous and extends from the external pore at the posterior end to the ovary.

These were collected from the bile duct of Felix viverrinius which died in the cattlo shod of a Huseum in France. ( Poirier $1886: 8)$

Op1othorchis geminus Looss (1896:50)

The body flattened, elongated, tapering anterforly, increasing in size pooteriorly. Totel length 7 to $8 \mathrm{~mm}$, in Circus aeraginosis 10 to 12.5 by 1 to $1.7 \mathrm{~mm}$ with a cephalad region $0.3 \mathrm{~mm}$. The greatest width $1.3 \mathrm{~mm}$. Oral sucker quite mall 0.1 ? 


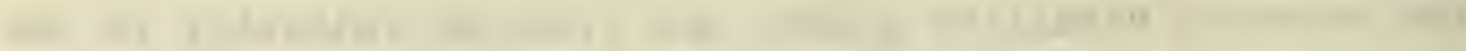

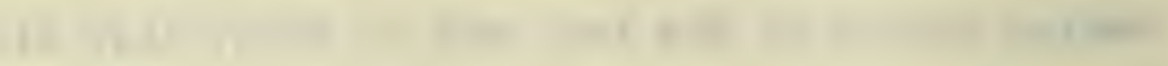

-

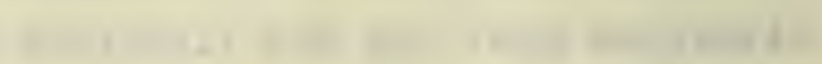

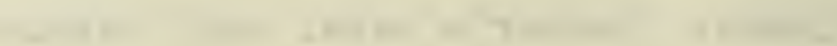

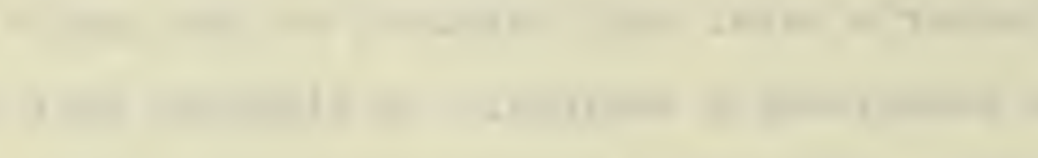

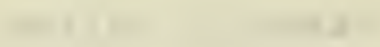

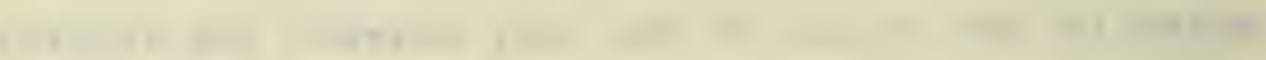
.

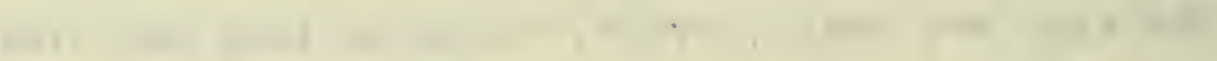

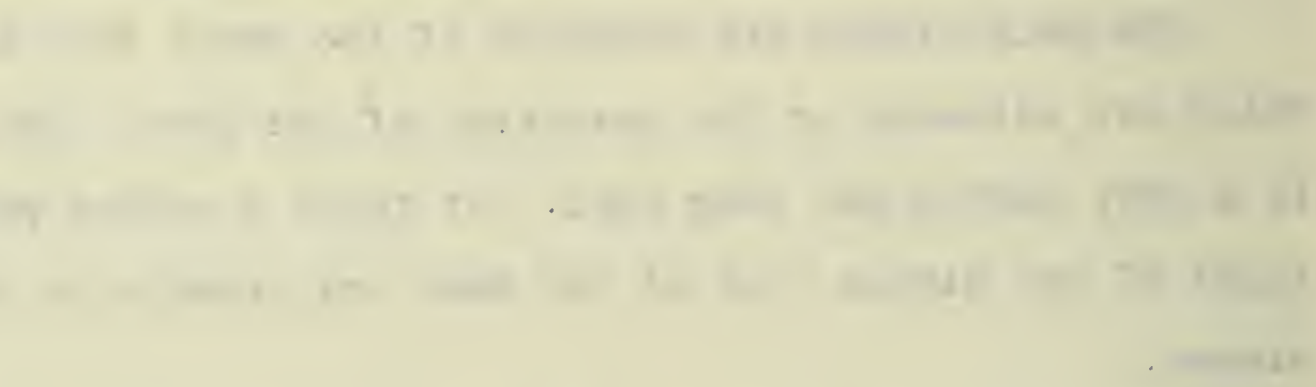

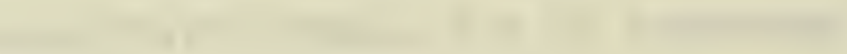

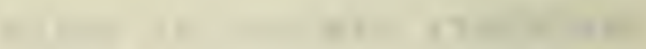

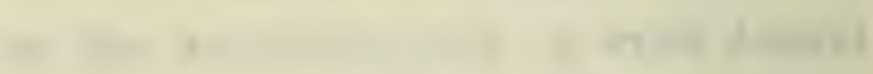
1

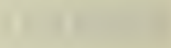

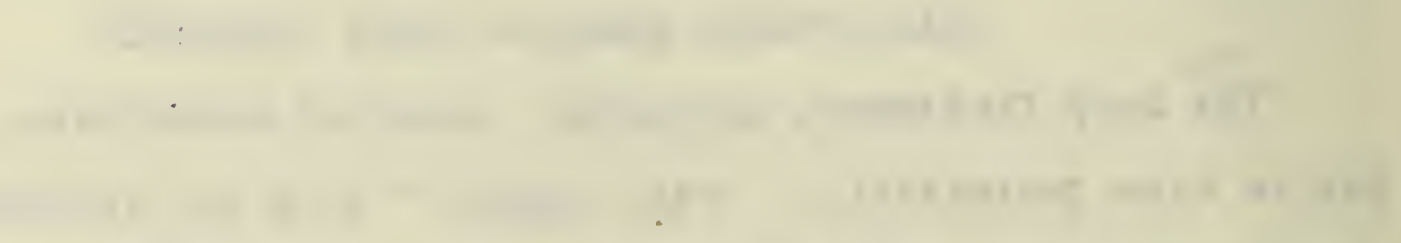

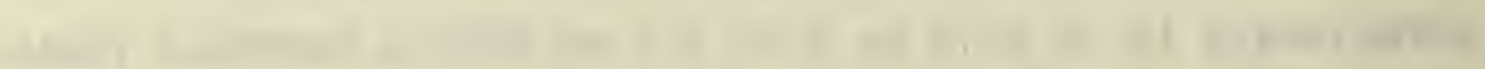
. 
$\mathrm{mm}$ in diameter. The oral opering subterminal. Acetebulum smaller than the anterior aucker, situated at the second fourth of the body.

The integunent very delicate, smooth and without any spicules or spinelets.

Digertive syatem - The mouth is followed by the small pharpnx measuring not more than $0.1 \mathrm{~mm}$ in diameter followed by the slender ovsophagus $0.25 \mathrm{~mm}$ long. The intestinal crura are not thicker than the oesophagus and extend almost to the posterior end bending elightly toward the median pland aying at the oldes of the excretory bladder at the extreme posterior end.

The Y-shaped excretory system curved slightly forming an "S" botween the teste日. The short branches at the anterior end do not extend over the intertine.

Genital gystem - The genital orifice is marked by a small opening immediately anterior to the acetabulum. Copulatdry organs not noteced. The two testes are not situated exactly at the midale line of the body. The anterior one is placed somewhat to the left, the posterior to the right. The anterior teatia four, the posterior usually five lobod; their greatest diameter not exceeding $0.6 \mathrm{~mm}$. Each gives a small vas efferens uniting at the middle of the body forming the vas deferens which is very large in diameterc.1 mm, and very long. After many tranaverse loope which do not reach the intestinal branches laterally it opens into the genital sinus.

The ovary usually trilobed, situated in front of the tester, is generally smaller than the testes and nearly in the middie line of the body. Laurer's canal is prominently curved and fillec with opermatozoa. In the interior of the germ auct cilia weo 


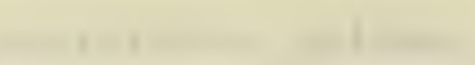

(n)

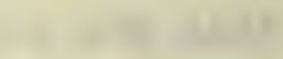

.

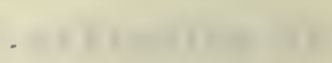

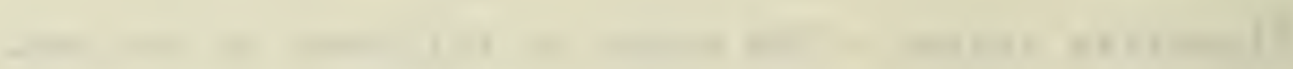

.

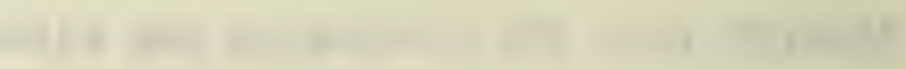

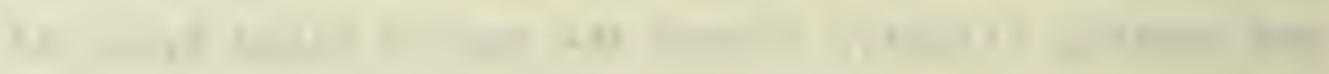

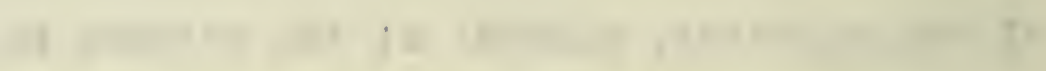

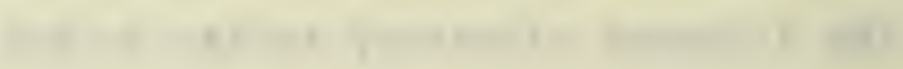

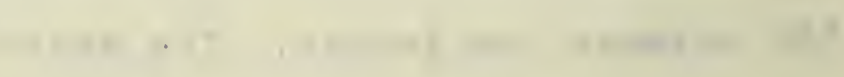

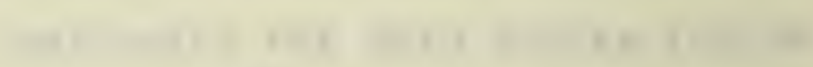

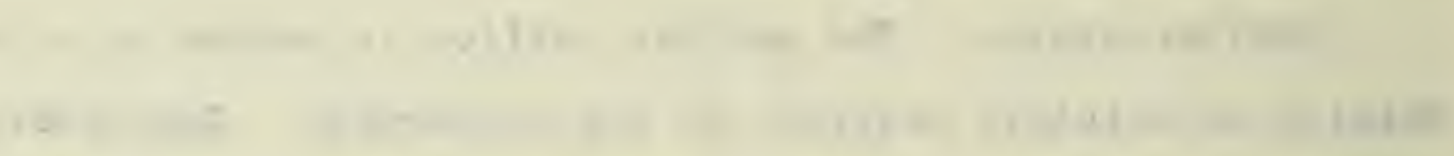

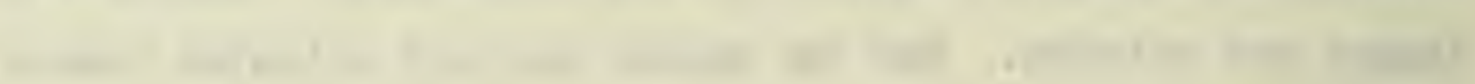


present. The vitellaria occupy the lateral portion of the body outside of the intestinal branchos. The vitelline glands begin about the anterior third or middle of the length of the body and extend not further than the poaterior end of the orary. The transverse ducts coneequently are posterior to the vitellaria. The course in fact is not perpendicular to the longltudinal axis of the body but extends sonewhat posteriorly. The much coiled uterus does not extend over the intestinal branches. It opens into the genttal sinus.

The eggs are oval in shape with a $11 d, 0.02 \mathrm{~mm}$ long and $0.01 \mathrm{~mm}$ wide. Perfectly developed embryos are seen in the metreterm region.

Habitat - In the biliary duct of Milvus parasiticus, Anas boschas fera, oircua aeruginosus.

Distribution - Egypt.

\section{Opisthorchis simulans Looss (1896:52)}

Three adult specimens and one young form found by Looss in the blliary duct of Pernis apivorus captured near Alexandria. The worme were located near the liver in the biliary pasage. The specific diagnosis - Body flat, elongated, anterior end lese tapering, posterior end alightly tapering. The length is 7 to $23 \mathrm{~mm}$, the greatert width across the middle of the body $1.5 \mathrm{~mm}$. The narrow anterior end $0.6 \mathrm{~mm}$. The anterior sucker surrounding the oral opening is terminal, it is relatively large, strong and measures $0.5 \mathrm{~mm}$ in diameter, the acetabulum on the other haxd is quite small and does not measure more than $0.2 \mathrm{~mm}$ in diameter, It is situated noarly at the lefel of the anterior third of the body . 
.

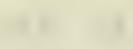


The integument is smooth without spines or spinelets.

Digestive system - The pharynx well dereloped $0.3 \mathrm{~mm}$ in dieweter noarly in contact with the befurcation of the crura so that no oesophagus is present. The crura run to the postericr end of the body widening a little at the extremity.

The nerrous syetem - The nerrous gyetem is similat to that of the other members of this genus.

The excretory system - The excretory stetem is Y-shaped. The unpaired bladder winds between the testes and has two short branches, into which opens a system of vessels at the sides of the ovary.

The genital system. - The genital orifice is at the anterior border of the acetabulum and opens into the genital sinus. The testes have a median position are spherical or elongated, $0.6 \mathrm{~mm}$ in diameter. The resa efferentia start from the lateral anterior borders of the testes and foin $0.8 \mathrm{~mm}$ posterior to the middle of the acetabulum. By this union they form in this species the single vas deferens $0.1 \mathrm{~mm}$ in maximum diameter which opens into the male orifice after having a winding course.

The ovary is quite small, lobed (follioular) and is situated in front of the testes at the loft and adjoining the midcile plane of the body. The receptaculum seminis is small and club shaped. Laurer's canal is quite short and a littlo swollen at the region which followe the recoptaculum seminis. At the anterior portion of the oviduct as in other parts cllia are present. The vitellaria occupy the space at the sides of the body outside of the intestinal branches. Thoy are very much ramified and extena to the anterior border of the anterior testis. The uterus occupies 


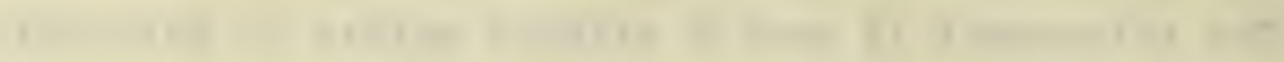

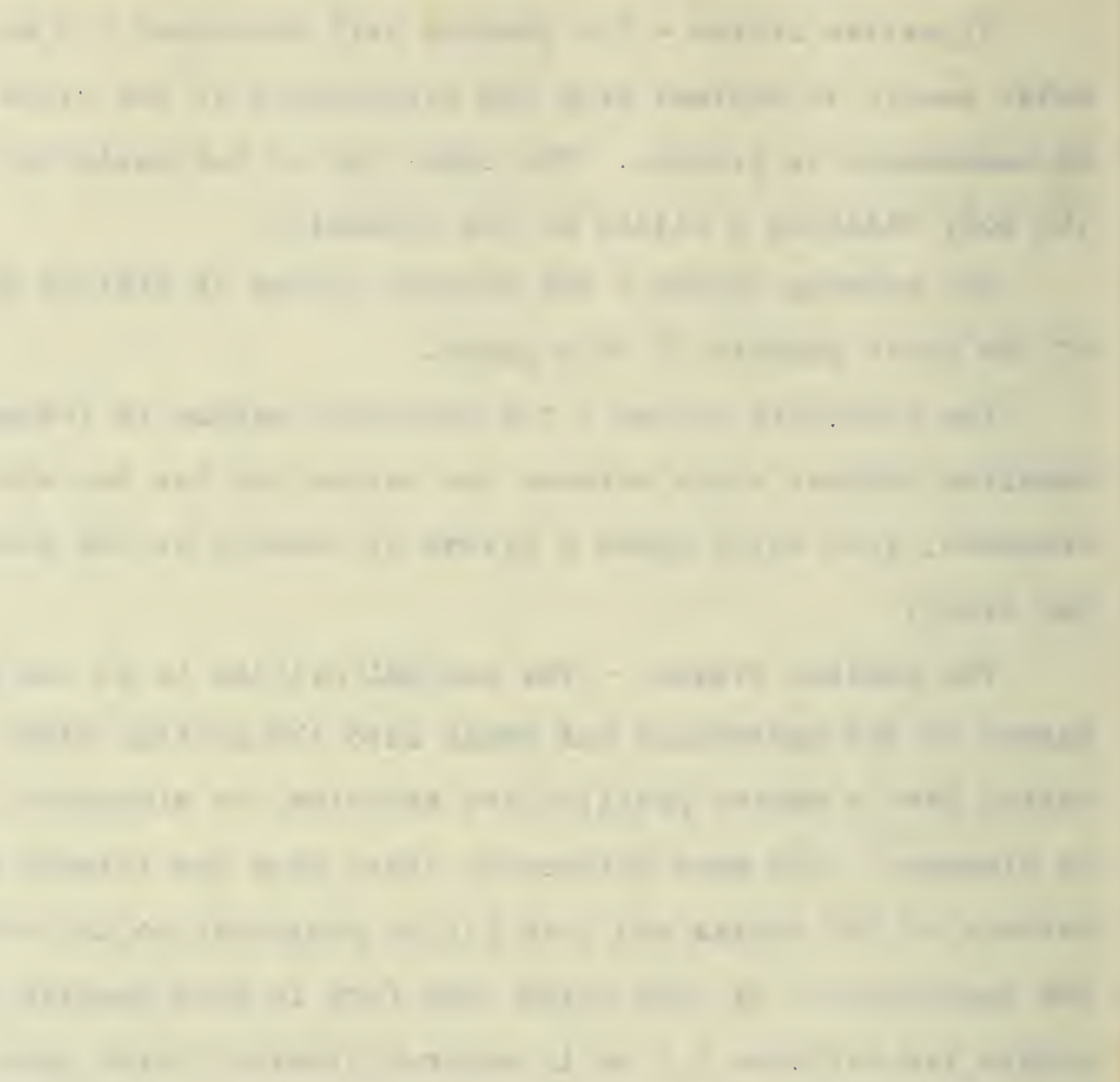

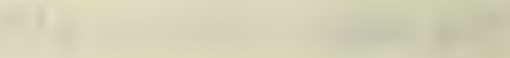

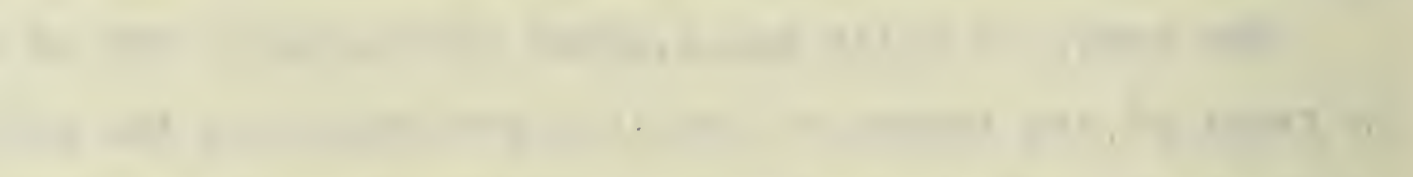

.

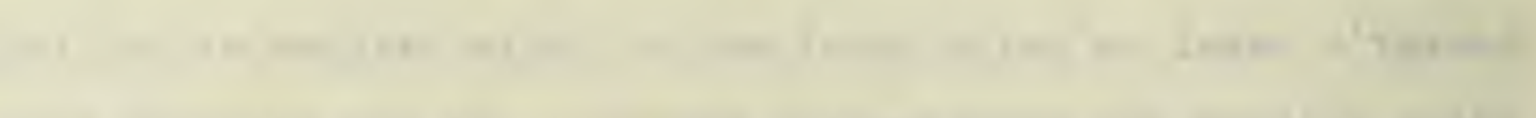

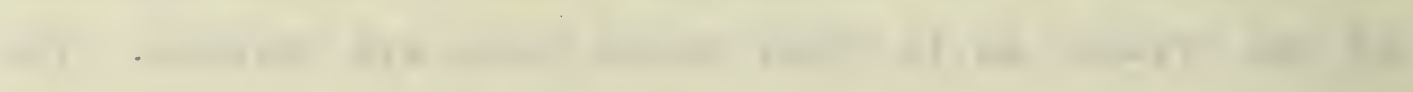

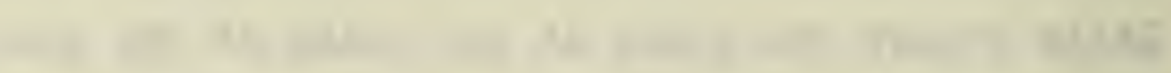

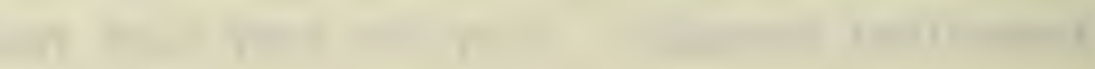


the anterior portion of the female ganital organs. The loope wind transversely and do not extend over tho intestinal crura, it opens into the common genital sinus.

The egge are larger than in 0. geminus and measure $0.028 \mathrm{~mm}$ in length by $0.018 \mathrm{~mm}$ in width. The operculum is a little thinnes The shell in thin but less transparent on account of the brown color. Eggo in the region of the metraterm have not developed embryos.

Habitat - Liver of Anas penelope, Fulix cristata, Ciroug aeruginosus and Pernis apivorus.

Distribution - Egypt.

Opisthorchis obsequens Nicoll (1914:106)

The body is very much flattened with crenate edgea. The anterior end is considerably attenusted but the posterior end is rounded. A small knob-like tip projects however from the anterior end. The adult specimens measure 2.6 to $5.0 \mathrm{~mm}$. The maximum breadth which occurs in the post- acetabular regicn, varies from 0.8 to $1.2 \mathrm{~mm}$. The average specimen measures 3.7 by $1 . \mathrm{mm}$. There are no spines. The oral sucker is almost terminal and measures 0.16 by $0.20 \mathrm{~mm}$ on the average. Its transverse diameter varies from 0.15 to $0.24 \mathrm{~mm}$. The ventral sucker measures $0.26 \mathrm{~mm}$ and is stuated $1.24 \mathrm{~mm}$ from the anterior end, which is oxactly one-third of the body length.

There is no prepharynx. The pharynx has a diameter of $0.12 \mathrm{~mm}$ and is slightly longer than broad. The oesophagus is about $0.19 \mathrm{~mm}$ in length with a range of 0.13 to $0.29 \mathrm{~mm}$. The intestinal diverticula are sinuous and narrow with crenate walls, especdally on their inner side. They extend to within $0.2 \mathrm{~mm}$ of the 


\section{-}

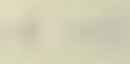

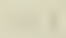

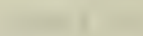

\section{-}

$+2$

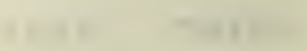

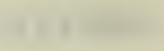

+n:

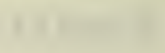
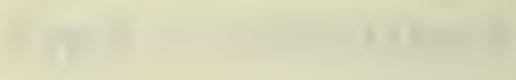

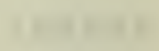

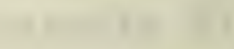
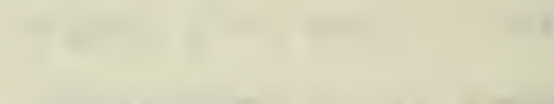

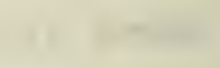

-

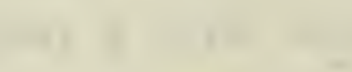


posterfor end of the body. Therr ende are turned in towards the middle line.

The excretory vesicle has the usual sinuous configuration observed in the other species of the genus. The posterior cures may be either towards the right or to the left. The bifurcation occurs just behind the ovary and the limbs are short.

The genital aperture is median and immediately in fromt of the ventral sucker. The vesicula seminalis is short and highly convoluted. It extends beyond the ventral sucker for a distance about $0.3 \mathrm{~mm}$. The testes are very much lobed, almcst dendritic. There are usually five lobes on the anterior testis and four on the posterior; but this is not invariable. They are more or less tandem, while there is always a strong tendency to obliquity, the anterior testis being usually displaced to ards the left oide. Amphitypy occurs frequently. The posterior testicular space mearures $0.34 \mathrm{~mm}$ which is about one-eleventh of the body length.

The ovary lies in front of the tester and is almost median. It is excesifively bobed, there being usually three lobes directed backwards. It is much smaller than either of the testes. The receptaculum seminis is of median size, pear-shaped and lies as a rule on the right. The yolk glands extend from the level of the middle of the ventral sucker to the level of the anterior testis and usually not beyond. They lie entirely to the outer side of the intestinal diverticula and consiat of elght groups of follicles on either side. The transverse yolk ducts meet at a very obture angle in fromt of the ovary. The uterus entirefills the space getween the ovary and the ventral sucker. It forms from the fourteen to sixteen transverse convolutions which occasionaliy touch, but do not overlap, the intestinal diverticula 


.


The egg measures 0.025 to 0.030 by 0.014 to $0.017 \mathrm{~mm}$ the average being 0.028 by $0.0155 \mathrm{~mm}$.

Habitat - Liver of Hieracidea berigora (brown Hawk) and Hieracidea orientalis.

Distribution - North Queensland.

Opiathorchis entre Von Ratz, (1900: 53z-534)

"Body flattened dorso-ventrally, lanceolate in shape and transparent; anterior portion whitish and posterior brownish yelIow; anterior end tapering and constricted at the lefel of the acetabulum forming a neck reglon anterior to the acetabulum; postterior portion of the body broader and the end rounded; length 12 to $13.2 \mathrm{~mm}$; breadth at the widest part 1 to $1.2 \mathrm{~mm}$. Oral sucker $0.25 \mathrm{~mm}$ in diameter; acetabulum $3.38 \mathrm{~mm}$ posterior to the oral sucker and a little larger, measuring $0.31 \mathrm{~mm}$ in diameter. Pharynx oval or heart shaped and followed by a short owophagus and forked intertinal tract, the crure ending in blind enlargments In the posterior end of the body. Cirrua and cirrus aa absent. Teater lie in the posterior half of the body, the one behind the other, 4 to 5 lobed. Vas efferens from each testes unite to form the vas deferng which passes forward to the genital pore situated just anterior to th acetabulum. Ovary in the middie of the body and slightly lobed, the retort shaped receptaculum sominis and tubular Laurer's canal just posterlor to the ovary. Vitellaria lateral to the intestinal caeca and extend from near the acetabulum to the ovary. Acini of the viteline glands somewhat indefinite being crowded together in spaces. The viteline glande extend farther cephalad on the right side than of the left. The two vitelline ducts, one from each side, lead posteriorly to 

the ovary where they unite. Uterine coils well developed and fill the body between the integtinal crura and the ovary and the acetabuium, but the coils do not extend over the intestinal crura. The ahell gland is distinct and just anterior to the ovary. Egga oval, more pointed at the anterior eno where the operculun with an opercular rim is found. They measure $0.0242 \mathrm{~mm}$ by 0.0132 to $0.0154 \mathrm{~mm}^{\prime \prime}$.

$$
\begin{aligned}
& \text { Habitat - Blue Heron (Ardea purpurea L) } \\
& \text { Distribution - Hungary. }
\end{aligned}
$$

Opisthorchis tenuicollis Rud. (1819:426)

Specific diagnosis - Body lanceolate, flat anterior end markedly tapering and thin, posterior ond bluntly pointed; body 6.5 to $10.12 \mathrm{~mm}$ by $1.12 \mathrm{~mm}$. Oral sucker 0.134 by $0.152 \mathrm{~mm}$. Acetabulum $0.319 \mathrm{~mm}$ in diameter, situated between the firat and second fourth of the body. Cuticula without spines. Ovary oval, smooth Receptaculum seminis well developed. Laurer's canal and sholl gland not mentioned. Teates in the posterior fourth of the body. Four to five lobed. Vitellaria in one region lateral to the intestinal caeca. Viteline glanda begin just posterior to the acetabulum and extend to the ovary. Uterus profuesly developed. Eggs ellipticel. 0.0228 by $0.014 \mathrm{~mm}$.

Habitat - Reported from the domertic cat? dog? and man? Gulo borealis, Poos barbata, Halichorus grypus, Erignathus barbatus, Dephinus phoceena, Phocaena phocaena.

Distribation. - Europe. 


\section{$-16-$}

lies in the region of the middle of the body. From that the worm tapers strongly toward the anterior, much less strongly toward the posterior. The forward end is rounded. The first part of the posteriar and behind the testes is abruptly pointed. Mouth opening oircular 0.19 to $0.22 \mathrm{~mm}$ in diameter, ventral acetabulum transversiy oval. 0.25 by $0.3 \mathrm{~mm}$. Situated in the end of the first body fifth. The body is armed with small broad spines. The pharyanx is $0.03 \mathrm{~mm}$ in diametex. Testea strongly lobed lying in the median line. Ovary is more or 208 s crenate. Genltal glands immediately posterior to one another. The vitellaria extends from the posterior end of the ovary anteriad to the middle third of the body, Ripe eggs $0.021 \mathrm{~mm}$ long and $0.011 \mathrm{~mm}$ broad.

Habitat - Gall bladder of Nile fish (Gymnarohus niloticus) Distribution - White Nile. Omdurman.

Opisthorchis pseudofelineus Fard (1895:152-158)

Body elongated, transparent, flat; length 5 to $22 \mathrm{~mm}$; breadth I to $2.5 \mathrm{~mm}$. Anterior end conical; posterior end rounded. Oral sucker 0.34 to $0.541 \mathrm{~mm}$. Ventral sucker 0.24 to $0.28 \mathrm{~mm}$ in diameter, situsted about one-fourth of the total length of the body from the oral sucker. Pharynx 0.12 to $0.25 \mathrm{~mm}$. long by 0.14 to $0128 \mathrm{~mm}$ wideand nest to the oral sucker, owsophagus short 0.04 to $0.38 \mathrm{~mm}$ in lehgth; branches of the intestine extend nearly to the posterior end of the body. Two lobed testes in the posterior third or fourth of the body, the posterior lying obliquely caudad to the anterior. Anterior orblcular, oval or elliptical in shape; margin smooth, wayy or 2 to 5 lobed. Ovary elliptical, orbicular or oval in shape with margin smooth, wavy or lobed, situated a little in front of the terter. Receptaculum seminis perr, oval 

or bag shaped, right or left of the ovary. Shell gland diffuse. Laurer's canal prominent. Uterue in coils from the ovary to the ventral sucker. Vitellaria lateral, occupying the middle third of the body and extending posteriad to the posterior tertio. The transverse vitelloduct passes from each region of the vitellaria? ovarnal and unites before or agter reaching the ovary. The break of the vitellaria in front of the ovary varies in extent from 0.06 to $1.3 \mathrm{~mm}$. Eggs long oval in shape, cap distinct with an operoular rim at the junction of the cap and the egg proper. Length 0.0286 to $0.0357 \mathrm{~mm}$ by 0.014 to 0.0162 in width. Tho excretory bladder is Y-shaped. The excretory canal signold.. The genital pore at the anterior margin of the acetabulum. Skin provided by minute needle like spinezets on the anterior portion of the body as far caudad as the ovary. Spinelets deeply inbedded in the cuticula.

Habitat - Biliary ducta of the domestic cat and a pet Coyoto. Distribution - Nebraska and Iowa - E. S. A.

\section{Opiothorchis interruptus Braun (1901:5)}

The animals are flattened, of band like form, the sides of the body wavy, tapering anteriorly, posterior broader than the anterior. The extreme posterior end pointed. 7 to $8 \mathrm{~mm}$ in length; in the region of the acetabulum $0.5 \mathrm{~mm}$ in width; at the testes $0.7 \mathrm{~mm}$. The oral sucker subterminal 0.25 to $0.25 \mathrm{~mm}$ brasd, acetabulum $1.35 \mathrm{~mm}$ in diameter, and $1.3 \mathrm{~mm}$ posterior to the oral sucker. A distinct prepharynx is wanting, the pharynx is 0. 104 by $0.125 \mathrm{~mm}$. The oesophagus has the ame length as the pharynx. The two wide intestinal crura extend to the posterior end, one orus being longer than the other. The posterior teatia 110 a in 

front of the posterior body wall by a diatence of 0. ? to $0.8 \mathrm{~mm}$; diagonally to this the anterior testes; they are not of tho same size and form, the anterior four lobed, the posterior is larger more nearly round and has less lobes. Between the testes runs the S-shaped excretory bladder. The receptaculum seminis is round or pear shaped and is smallex than the testes. Ovary median of the same size as thetestes, oval in shape and lies just in front of the receptaculum seminis. The uterus coils transversely and is compact, the genital pore is aituated immediately anterior to the acetabulum. A ofrrug pouch is ebsent. The aggs are dark colored, 0.023 by $0.01 \mathrm{~mm}$ in size. The small vitelline folliclet have a grouping distinctly as in the other species of the genus Opisthorchio; they begin anteriorly behind the acetabulum at a different level on each side, posteriorly they reach to the posterior testis. The distance of the enterior end of the vitellaria from the acetabulum is equal to the distance from the acetabulum to the oral sucker. It is characteristic that in the region of the receptaculum and as well in the ovarian region, an apparently long break in the vitellaria appeara on both sides. This $1 \mathrm{~s}$ approzimately $0.6 \mathrm{~mm}$ long. The forms from the intestine of Ardea viridirufa appear to belong to the same species as they have the same length, the suckers and egga are the same alze and in every other respeot correspond to 0 . interruptus, the vitellar1a hovever could not be made out in those from Alcodo virescens. Habitat - Ardea viridirufa and Aleedo virescens. Diatribution - Brazil. 

The length of tine body 5.5 to $12.5 \mathrm{~mm}$. The greatest width 1 . to $2.8 \mathrm{~mm}$. The nock region is one third the total length of the entire body, is conical and elliptical in cross section. It carries on ite forward end a subterminal oral sucker. The walls of the neok show a smooth wavy appearance, while that of the posterior end appeara serrated. The oral sucker measures 0.33 to 0.36 $\mathrm{mm}$ by 0.56 to $0.66 \mathrm{~mm}$. Acetebulum in anterior third of the body 0.51 to $1.2 \mathrm{~mm}$ in diameter and is more spherical than the oral aucker. A prepharynx is wanting. The ossophagus is short, intestinalorura reach to the posterior tapering end and run somewhat parallel. The excretory system is Y-shaped, the main branch winding in an S-shape between the testes to the excretory pore, which 1s terminal. The anterior teatis 18 situated on the left and has four lobes, the posterior on the right with five lobes. The cirrus pouch is absent. The genitaz pore is situated median immediately anterior to the acetabulum. The receptaculum eeminis is apindle formed, The ovary is biscult shaped. The shell gland is indistinct. The eggs are oval 0.029 to $0.033 \mathrm{~mm}$ by 0.012 to $0.014 \mathrm{~mm}$. The vitellaria lateral to the intestinal crura, extand from the posterior of the acetabulum to the bevel where the crura end. They are formed of small cross running acini, which combine in more or 1888 distinct groups. On each side there are eight such groups of acini. The palred vitellind ducts begin usually between groups 4 and 5 of the acini, a space being here so that the vitellaria has two regions, and anterior ovarial and a posterior ovarial region. Amphitypy is evident in this вpecier.

Habitat - Male Delphinus tacuschi (Steno tucuxi Gray) Orcella brevirostria 


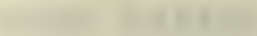

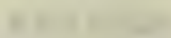

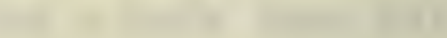

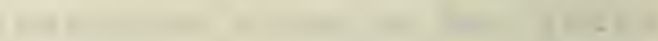

$\left(\frac{10}{2}\right.$

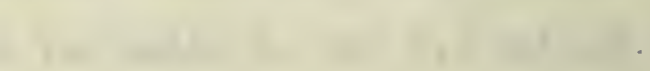

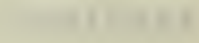

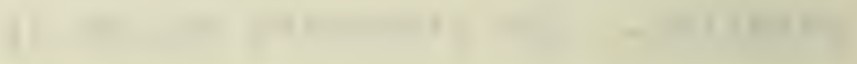

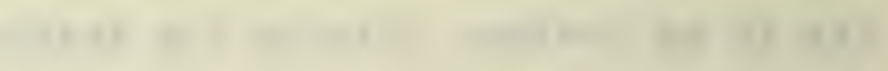

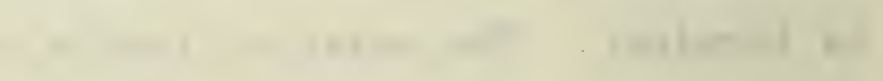

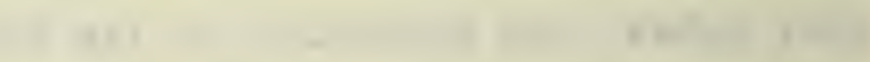

1

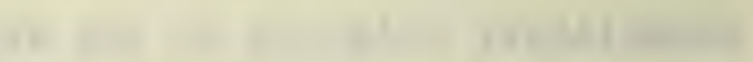

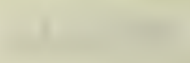

(1)

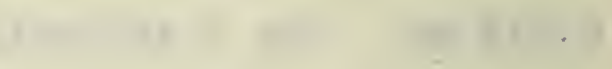

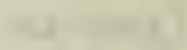

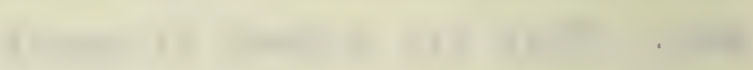

10

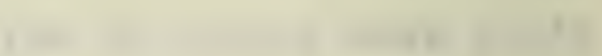


Diatribution - Barra do Rio Negro, Brazil.

Op1sthorchis oval1s, Barker (1911:518)

General shape of the body slender and oblanceolate, the anterior end tapering and bluntly conical, the posterior end broader and tapering slightly towards the end, There is a well defined narrower region or neck anterior to the acetabulum; the length of the body measures 6 to $14.32 \mathrm{~mm}$; the breadth across the acetebulum 0.342 to $0.81 \mathrm{~mm}$; across the ovary 0.45 to $1.373 \mathrm{~mm}$. Small needle like, retrose oplnelets abundant over the anterior two-thirde of the body, being most abundant at the atterior end as far caudad as the acetabulum and becoming sparser until the region of the ovary; in these specimesn these opinelets werequite abundant. The oral sucker is subterminal 0.198 to $0.36 \mathrm{~mm}$ by 0.198 to $0.378 \mathrm{~mm}$. The acetabulum in the anterior fifth, sixth, or seventh of the body, mearuring 0.1331 to $0.216 \mathrm{~mm}$ by 0.131 to $0.225 \mathrm{~mm}$. The genital pore immediately anterior and median to the acetabulum. The pharynx 0.188 to $0.15 \mathrm{~mm}$ by 0.108 to $0.152 \mathrm{~mm}$. The oesophagus 0.09 to $0.63 \mathrm{~mm}$ in length. The intestinal crura 8re unequal in length and extend to the posterior end. The tegtes are in the posterior third of the body, oval ovate or orbioular, smoth or slightly lobed. A cirrus is absent. Ovary oval, ovate or orbicular, smonth or 11 ightly crenate. The receptaculum prominent, two to four timea the $81 \mathrm{ze}$ of the ovary. Laurer's canal prominent. Shell gland diffuse and somewhat indibtinct; uterine coils of median density and compactness. Vitellaria lateral to the intestinal caeca, divided into two destinct reglons by a break near the ovary. Vitelline glands begin 0.36 to $1.89 \mathrm{~mm}$ posterior to the acetabulum and extend to 
i11:

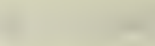

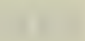

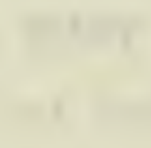


the posterior teatis. Eggs short ovals in form, measuring 0.025 to $0.312 \mathrm{~mm}$ by 0.014 to $0.019 \mathrm{~mm}$, with distinct lid but no opercular rim.

Habitat - Bile ducts of soft shell turtles (Trionyx spinifer Lesson and Trionyx muticus Lesseur) and Chrysemys matginata.

Distribution - Mississippi river in Minnesota and Iowa, U. S. A.

Opisthorchis noverca Braun (1903)

Syn:- Distoma conjunctum Lewis and Cunningham 1872

Distoma conjunctum McConnell 1876

Distoma conjunctum Cobbold 1859

Body lancet shaped, spinous, 9.5 to $12.7 \mathrm{~mm}$ long by $2.5 \mathrm{~mm}$ broad. Suckers close together, the oral being larger than the ventral. Pharynx spherical, intestinal crura extending far posteriad. Genital pore immediately in front of the acetabulum.

Testes round or only slightly lobed, situated at the limit of the posterior third of the body and nearly opposite. Ovary slightly lobed, in front of the bifurcation of the $\mathrm{Y}$-ahaped excretory reservo1r. Uterus in 100 p through the central area from the ovary to the genital pore. Vitellaria lateral, beginning at the bevel of the acetabulum, extending to the midale of the posterior testis. A break of the vitellaria occurs in front of the ovary but it is indistinct. No cirrus sac. Eggs oval 0.034 by 0.021 $\mathrm{mm}$.

Habitat - Gall ducts of man.

Distribution - India. 


\section{$-22-$}

Opisthorchis caninus Barker (1911)

Syn:- Distoma conjunctum Lewis and Cunningham 1872

Opisthorchis noverce Braun 1903

Parppisthorchis caninus Stephens 1912

Opisthorohis ceninus Barker 1911

Body slightly lenceolate, length varies from 2.75 to $5.75 \mathrm{~mm}$ in preserved specimens. Average length 3.6 to $5.8 \mathrm{~mm}$. Body unlformly spinose. No spines on the pedicle. Oral sucker $0.28 \mathrm{~mm}$. Pharynx 0.224 by $0.184 \mathrm{~mm}$. Oesophagus $0.04 \mathrm{~mm}$. The ventral sucker $0.176 \mathrm{~mm}$ in diameter. n The acetabulum on the acetabular papilia between the first and second anterior ifth; smaller than the oral sucker. Pedicle about $\frac{1}{2} \mathrm{~mm}$ long. May be completely retracted. Genital pore on the apex of the pedicle in front of the acetabulum. Its exact position varies with the state of contraction of the parts. In certain cases it actually opens externally to the sucker and anterior to it. The goening is covered with scales. The vas deferens and uterue run alongside one another until they merge near the apex of the pedicle into a common sinus. The teates lie in the posterior third of the body, are orbicular or alightly lobed. One altuated obliquely in front of the other. Ovary multilobular, the lobes 5 to 8,irregular in size and shape. It is docated at the beginning of the posterior half. The semial receptacle is globular, situated to the right of and dorsal to the posterior lobe of the ovary. Laurer's canal usually runs from the end of the recentacle with a single curve medially and backwards. The uterine coils form loosely packed transverse coils terminating slightly in front of the level of the firat viteline acinus. From here the uterus pasges forward 


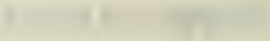
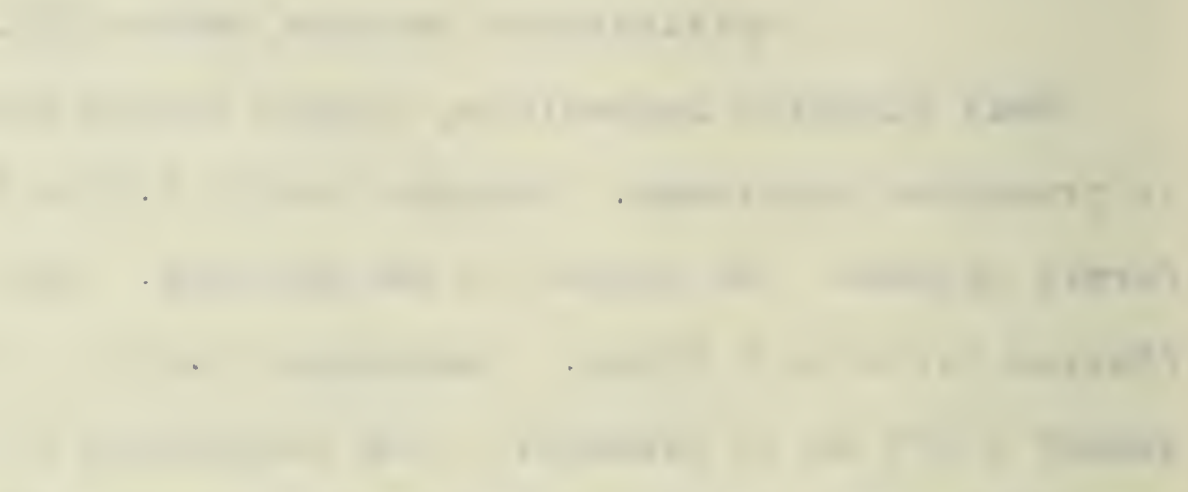

1

1)
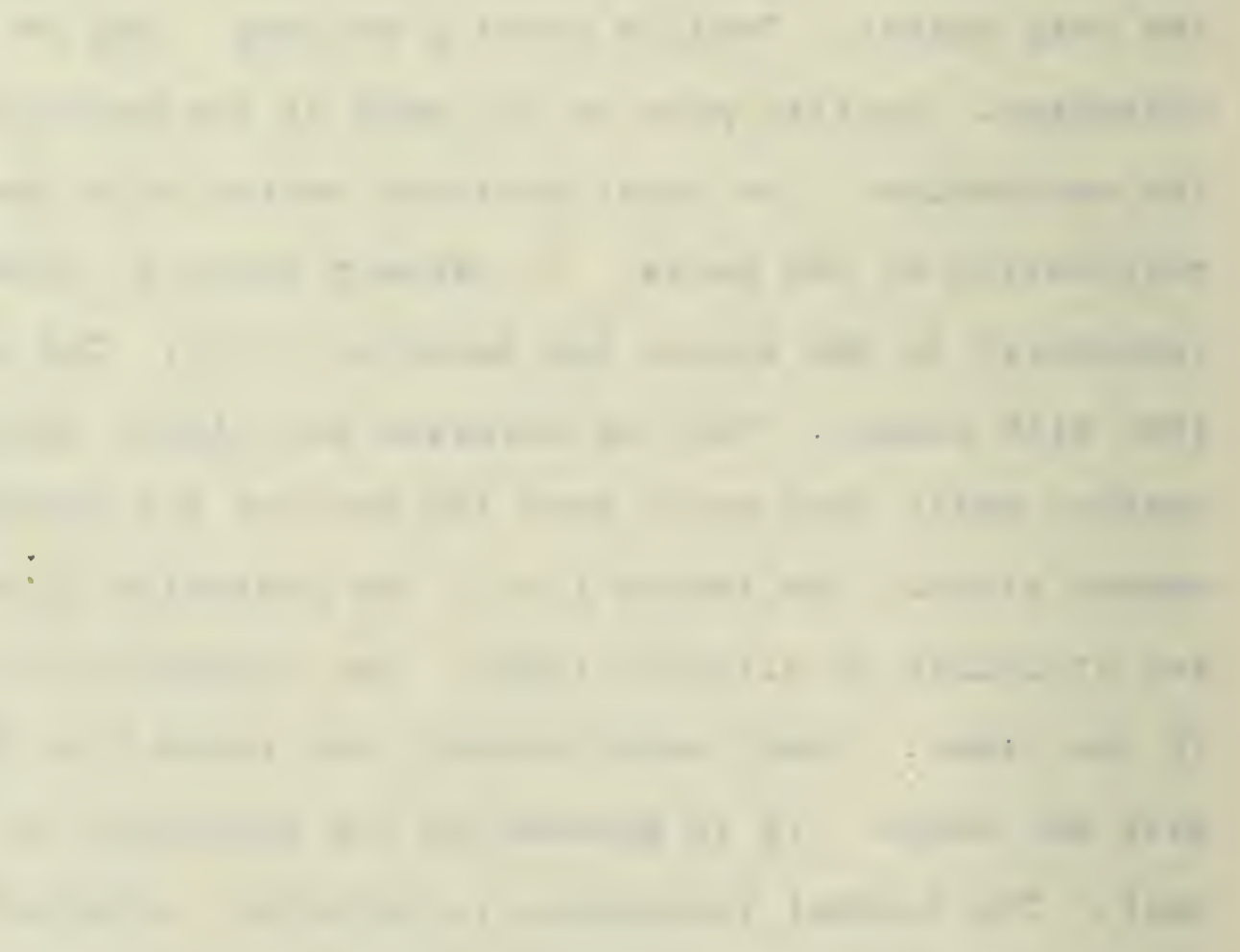
into the pedicle to the left and ventral to the seminal vertile. Seminal vesicle commencer about the level of the first viteline acini. The coils displace the uterus ventrally and to the left. In the pedicle the vesicle diminishes in extent and ries in its dorgal (anterior) side.

$$
\begin{aligned}
& \text { Habitat - Liver of Parial doga. } \\
& \text { Distribution - India. }
\end{aligned}
$$

Opisthorchis speciosus Stiles \& Hassall 1894 Syn:- Distoma (Dicrocoelium) longissimum var. corrinus Stiles and Hassall 1894

Opisthorchis speciosus Stiles and Hassall 1896

Body elongated, its narrow and tapering anterior end covered with retrose spinelets, length 7.6 to $29 \mathrm{~mm}$ by 0.666 to $1.332 \mathrm{~mm}$ wide in the region of the ovary. Oral sucker subterminal, 0.291 to $0.366 \mathrm{~mm}$ by 0.291 to $0.357 \mathrm{~mm}$. Acetabulum in the anterior third or fourthof the body, 0.178 to $0.244 \mathrm{~mm}$ by 0.178 to $0.344 \mathrm{~mm}$. The pharynx 0.15 to $0.205 \mathrm{~mm}$ by 0.131 to $0.188 \mathrm{~mm}$. The oesophagur 0.15 to $0.30 \mathrm{~mm}$ long. Intestinal caeca equal or unequal, extend to the posterior end. Testes in posterior ejght of the body, orbicular or oval, smooth or four lobed, Cirrus absent. Genital pore not prominent, at the anterior mergin of the acetabulun. Ovary in posterior fifth of the body, oval, ovate or elliptical., smooth to three lobod. Receptaculum seminis smaller than or equal to the ovary. Shell gland diffuse or distinct. Laurer's canal prominent. Uterine colls vory dense and close. Frequently extending laterally over the intestinal crura. Vitellaria divided in to two distinct regions by a break in front of the ovary. Vitelline glands begin 0.803 to $0.263 \mathrm{~mm}$ posterior to the acet- 

abulum and extend to the posterior testis. Eggs long ovals, with distinct 1 dd and opercular rim, 0.085 to 0.033 by 0.015 to $0.018 \mathrm{~mm}$ Habitat - Bile ducts of Crowg (Corvus americanus, Corvus oseifrage) and the frog.

Distribution - Maryland and District of Columbia, U. S. A.

Barker, F. D. (1911) divided the genus opisthorchis and proposed the generic name Amphimerus for those species which had two vitellaria regions caused by a break in the line of acini near the ovary, as postovarial and antovarial regions, while those forms which had only one region he retained in the old genus opisthorchis

Genus Amphimerus Barker (1911:536)

Generic deagnosis - Fasoiolidae; body flattened, elongated, anterior end tepering. Skin frequently covered wholly or in part by mall retrose spineleta. Excretory system Y-shape with signoid stem winding between the testes. Copulatory organs absent. Testes in posterior portion of the body, simple or lobate; the one obliquely posterior to the other. Ovary anterior to the teates, simple or lobate. Laurer's canal present; recoptaculum suminis well developed. Uterine coils anterior to the ovary and may extend laterally over the intestinal caeca. Vitellaria well developed, lateral to the intertinal crura and divided into two distinct regions by a break op posite the ovary. Not extending anteriorly bezond the acetabulum but frequently extending posterioriy to or beyond the posterior testio.

Habitat - Parasitic in the gall ducts of mammals, birds and reptiles.

Type species - Amphimerus ovalis Barker (1911)

Stephens (1912) divided Opisthorchis once more retaining the 

generic name for all the gpecies exoept Oplathorchis caninua Barker which he placed under a new genus parapisthorchio.

Genus Paropisthorchis Stephens (1912)

Structure es in Opisthorchis; except that the ventral sucker and genital pore occur on the apex of a precess or pedicle projeoting from the anterior portion of the body. This process is about $0.5 \mathrm{~mm}$ long and is retractile. 



\section{ग. DISCUSSION}

"It is a fact well acknowledged by persons who have worked with species of the genus opisthorchis, that the forms in this genus represent one of the most difficult proglems to the systematiet", writes Looss (1899). "Several forms anatomically seem identical that should be classified as separate individualo on a biological basis" (1907). Opisthorchis felineus and 0.geminus without knowledge of ther host will be classified under the same species and in fact I am inclired to think 0 . tenuicolits is at most a variety of 0 . felinous. 0 . felineus is found in the 1 iver of man and the cat in Europe; but 0 . geminus in Egypt in the liver of the non-migrating Milvus parasiticus, Anas boschas fera, Circus aeruginosus. 0 . tenuicollis from seala in Europe. Feat to these three forms comes O.viverrini and o.entxi which differ from the above not in large detalis. Loose (1899) takea 0. geminus as a separate species on biological grounds. The above mentioned birds are native to Egypt and never migrate and if they are the same as 0 . felineus, cats and man should be harboring these parasites, however this has not been reported not has Looss been able to find any opisthorohis in mammals contrary to his special search. 0 . geminus iffers from the rest on the oame ground as it differs from 0 . felineus. Loose again makes a comparison between 0 . tenuicollis and 0 . geminus from unas boschas fera. 0 . geminue fron Anas 18 10. to $12.5 \mathrm{~mm}$ long and 1 . to $1 . ?$ mm broad; teates both lobed in 0 . tenuicollis and 0 . geminus. ovary of 0 . geminus from two different kinds of hosta varies slightly from that of Anas, being round or slightly lobed, but 

from Circlis more aistinctly lobed. Vitellaria same both in 0 . geminus and 0 . tenuicollis. The eggs of 0 . tenuiccllis as given b y Mthling 0.025 to $0.028 \mathrm{~mm}$ long and $0.013 \mathrm{~mm}$ wide, in 0 geminus 0.027 by $0.013 \mathrm{~mm}$ in Anas and 0.023 by $0.013 \mathrm{~mm}$ in Circus. By such comparison L008s finds these forms identical yet thinks they cannot be classified as one species for the same reason as 0 . felinaus cannot be the same as 0 . geminus, because of the specificity of the host. The same argument is brought about in regara to the nearly identical forms of 0 . tenuicollis and 0 . felineus. Braun in comparing the forms found by whling with 0 . felineus comes to the conclusion that they are different forme.

0 . entzi has very identical characters with 0 . tenuicollio which in turn is chosely related to 0 . felineus and 0 . geminus. It is taken as a separate species however by only specific differences of the euckers, in 0 . entze the acetabulum is larger than the oral aucker which in other forms is equal to it or the oral sucker is larger than the acetabulum. O. viverrini differs from the above mentioned form by the distinctly abbed ovary, by the moderately developed uterine collo and by the egg with an opercular rim. No figure accompanies Von Ratz's description of 0 . entzi whioh makes a comparison whth 0 . Viverrini less valuable. The forms discussed above differ from each other by one or two characters in general. Two other forms which are more distinctly separated from the rest aro 0 . Iongissimus and 0 . stmulans. Both of these have ovary very much lobed (follicular). In the figure of Looss (1891:52) this character is not noticeable but his figure in a later description(1898:673) gives these characteriatic: 10bes. The difference between 0. simulans and 0 . 


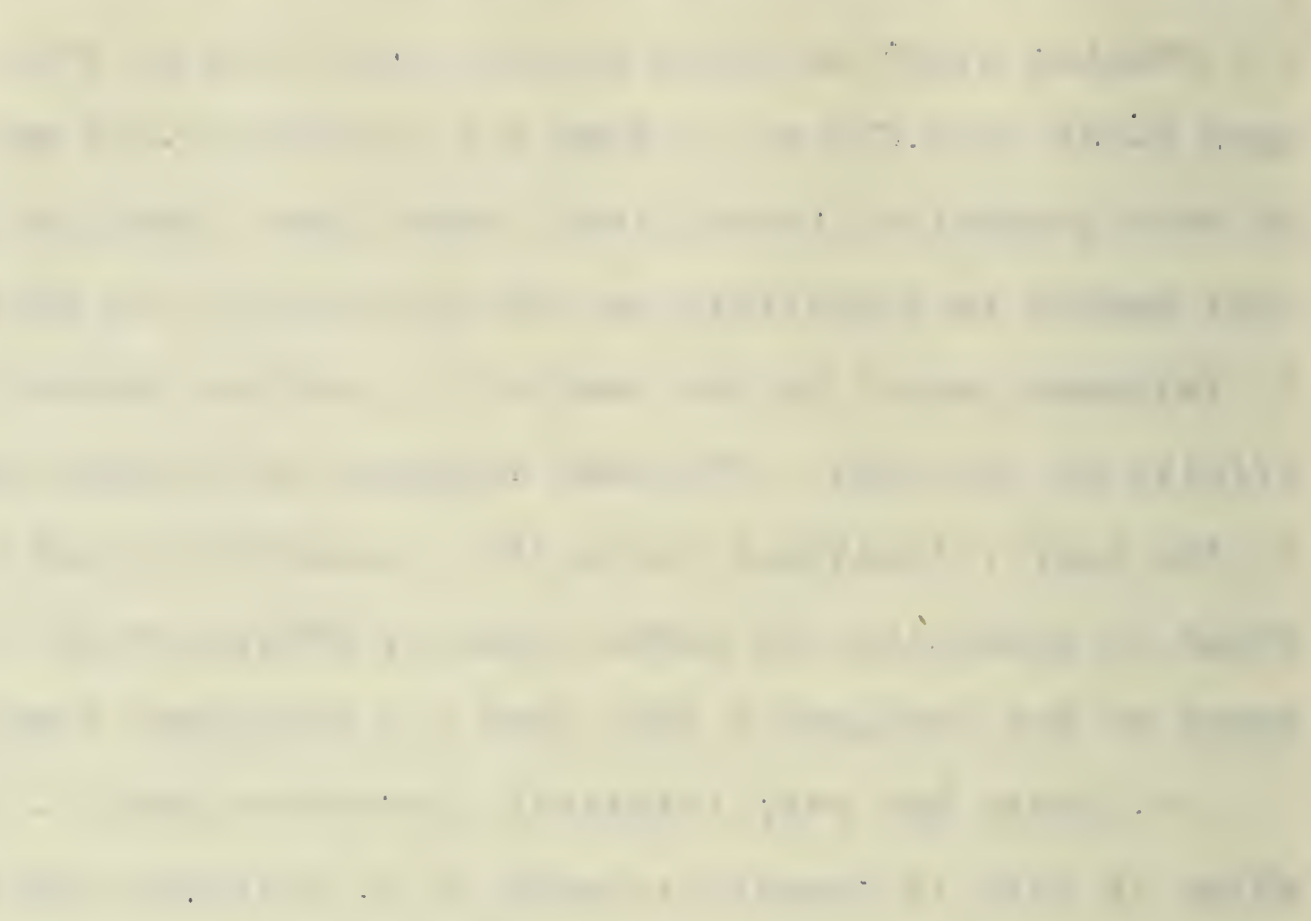


longissimus is quite small. 0 . longissimus tacers anteriorly but 0. aimulans only slightly. The reverse is the case posteriorly. The oral sucker in the later is much larger than the ecetabulum, the reverse is the case with 0 . Ionglesimus. The uterus coils are much closer in 0 . longissimus than in 0 . simulans. Testes in the former larger and somewhat lobed. Located more posteriorly than that in 0. eimulans which is more round, smaller and not not so much posterior. Some of these characters are much in variance as I have described in the case of 0 . viverrini var. Chiengma1. Yet the variationg in the same opecies are with in normal Iimit.

Opisthorchis obsequens Nicoll is distinguished by the smaller form, by its very much lobed testes which ougge日t the genus Clonorchis. The ovary is usually irregular in outline, ventral sucker is lerger than the oral eucker; vitellaria more continued.

0 . piscicola can be readily distinguished from the rest of the species by its minute size, with its relatively larger acetabulum. In this respect being much like 0 . obsequens but differs from it by its broad spines, lobed testes and its piscine host.

Another form described by Galli-Valerio (1898:145) and named as 0 . pianae is questioned by Kowalewski (1898: 751). Certain characters were overlooked which will make these forms identical with E. conoideum.

Gall1-Valerio (1898:933) tho admitting that this form may not belong to the genur opisthorchis maintains that it is not identical with El conoideum. From the description he refards it as Opisthorchis as it agrees with 0 . Blanchard. 

From his figure it is certa.in that it does not belong to the genus Opiathorchis as the vitellaria extend to the posterior end of the body in an H-shape. However I cannot pass judgment regarding this form being an Amphimerus from hio meager description. As Kowalewaki has made a careful study of these forms it is age not to include 0 . pianae in even Amphimerus.

Kowalewoki (1898:52) described a form 0. simulans var. poturzycensis from the liver of Anas boschas dom. He makes a comparison of this with 0 . simulane Looss and 0 . longisaimus. His comparison is based upon the description of Looss (1896:52). Looss (1899:674) describes another form of 0 . simulans with slight variation from Anas ponelope and Felix cristate. This form olightIy larger than that from Pernis apivorus correspond 3 to Kowalewski's drawing (Fig. 23) and description.

Barker's division of Opisthorchis into two genera is quietioned by some parasitologiots. Leiper( have not been able myself to consult Leiper's attiele on the subject) has objected to such diviaion on the ground that extent of the vitelleria posteriad is a matter of chance and not a generic characteristic. I have examined more than fifty specimens of 0 . viverrini and I find the variation in the extent of the viteliaria small. They never extend behind the anterior testis, usually the vitellaria end at the level of the ovary. I have never noticed any break in the Ine in that region. The number of acini, their anterior or posterior extent, and the number of acini bohind the transverse vitelline duct, does vary somewhat but always within a normal limit. Mthling (1896:261) examined sixty specimens of 0 . felineus and from the description I find the variation in 0 . felineus the 


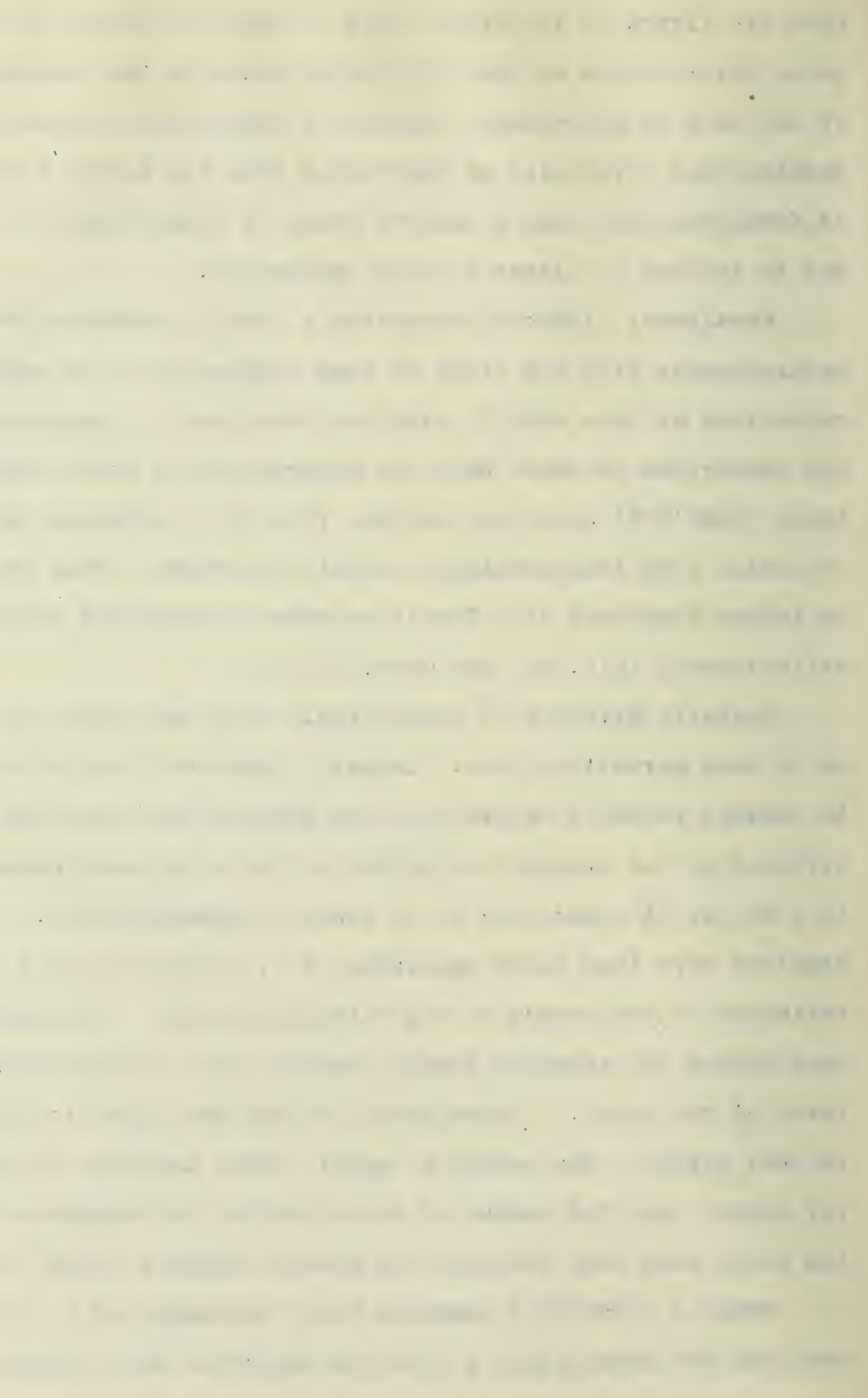


same as in 0 . viverrini. 0 . felineus is the type species of the genus Opisthorchis. I find from the descriptions the same thiog true for the vitellaria in all species of thed genus as modified by Barker. The other species of Opisthorchis are classified under the genus Amphimerus Barker. Thio new genus is based entirely upon the division of the vitellaxia into two regions, an antovarial and a postovarial with a diatinct break in the line of acini at the ovary.

Weski (1900) examined 400 specimens of 0 . Iancea Dies. for the extent of the variation of the vitellaria. In every case the vitellaria did extend caudad to the posterior testis which never was the case with 0 . felineus or the like. There was some irregularity in the Iine of acini opposite the ovary. In twentytwo cases only there was no break in the line of acini opposite the ovary on the right and only four on the left, but the acini were distinct. In 119 cases the groups coalesced on the right and in 35 on the left.

Fard (1894) describes the vitellaria in Opisthorchis pseudofelineus as follows, "Vitellaria extend to the middle of the space between the two or even as far as the anterior edge of the postericr testis. One break in the line of acind may always bo recognized as most prominent; it is loceded just opposite the ovary on each side, and is in length more or 1088 equal to the diamete-r of the ovary. This is the condition shown on the left side of lthe worm figured. This epace divides the vitellaria into two portions which may be distinguished as antovarial and postovarial. While it is in some cases possible to distinguish in the antovarial portion groups of acini they sesm to be usuallyrather indistinct 



\section{$-31-$}

or at least very unoqual in size, as if adjacent groups had bocome confluent by the growth of interlying acini. The posterior portion, however is usually distinctly divided intotwo or three group of acin1, though even these may be obliterated. In two or three cases a small group of acini was found, on one side only in this intermediate space opposite the ovary, and was clearly separated from both antovarial and postovarial portions by a small space. This was the case in the right vitelline gland of the worm figured, corresponding to the two portions of glands, one finds on each side two ducts which, extending obliquely toward the ovary from a short distance before and behind it, form a "Y" or "V" according as they meet before or are not united after reaching the ovary. Thege ducts on ither side of the ovary form one of the most characteristic appearances of the specimen".

Stiles (1904:32) describes these glands, "the antovarial portion four acini, postovarial three, each portion provided with its own oviduct, the antovarial portion extends frow the ovary oephalad to about the boundary between the anterior and equatoral thirds of the body; the postericr portion extends caudad from the ovary to about the anterior plane of the posterior testis."

Barker (1907:100) makes a detail description of the varlation of the viteliaria in 0 . Bseudofelinous from more than $a$ hundred specimens.

"The vitellaria never extend to the acetabulum, but their position posterior to posterior matgin of the acetabulum varies on the right aled from $0.3 \mathrm{~mm}$ to $4.5 \mathrm{~mm}$, the mode being $1.1 \mathrm{~mm}$ with frequency of 23 per cent. On the left side the grosition 


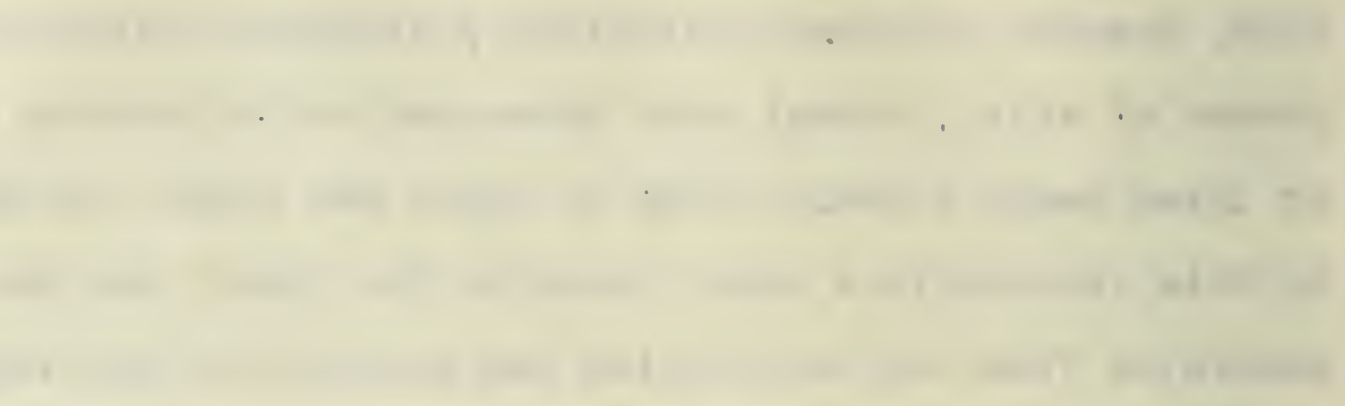


varies from $0.3 \mathrm{~mm}$ to $3.7 \mathrm{~mm}$ the mode being $0.7 \mathrm{~mm}$ with a frequency of 18 per cent

********** The extent of the vitellaria caudad varies from the anterior margin of the anterior testis to a place $0.07 \mathrm{~mm}$ to $0.30 \mathrm{~mm}$ posterior to posterior testis, with a frequency of 28 per cent for the right sido. On the left side the extremes were found to be a plade $0.16 \mathrm{~mm}$ anterior to the posterior teat1s the mode being the anterior margin of the posterior testis, with a frequency of 22 per cent."

From the above quotations we find that the variation in the extent of tie vitellaria in 0 . pseudofelineus is great but the break in the line of acini at the every quite constant. With al 1 the varlations 0 . pseudofelineus represents a homogeneous typo which stands separately. Forms belonging to this type are 0 . interruptus, 0 . lencea, 0 . noverce and 0 . speciosus and 0 . ovalis, all having viteliaria divided into regions and a distinct break taking place at the ovarial region. In 0 . noverca the same is true except that the break in the line of acini at the ovary 1 is 1808 distinct. In this later form the viteliaria extends from lateral areas behind the acetebulum to the posterior testis.

Barker(1911) mentions that Amphimerus noverca is the only form which does not preseht a break in the line of acini in fromt of the ovary. But rightly he questions the accuracy of McConnell's drawing. It seems that Barker has not noticed the figure given by Leuckart. In this there 18 a distinct break in the line of acini in front of the ovary on one side.

The topographic details of the two groups are identical, they are parasitic in the same animals in the same organs. A study of 


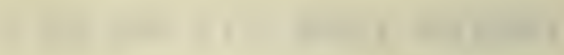

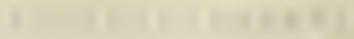

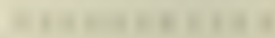

x.

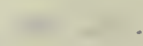

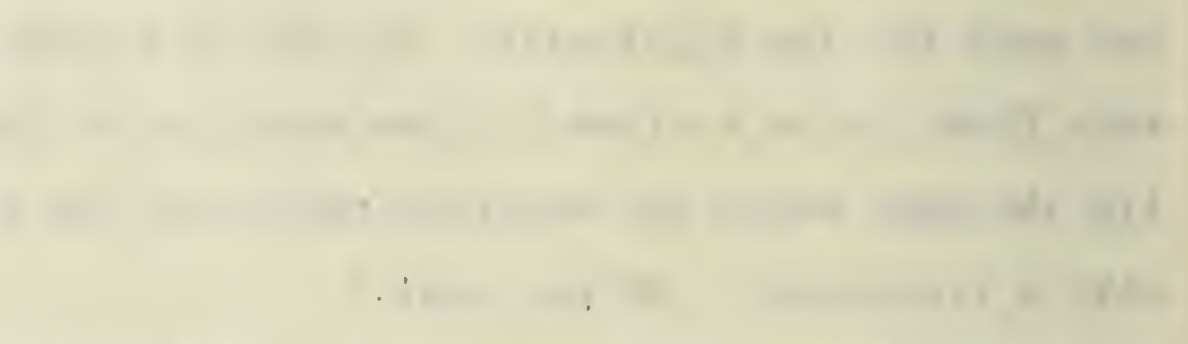

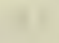

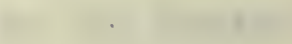

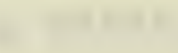

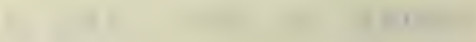

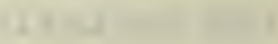
.

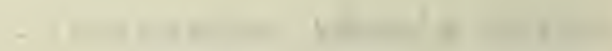

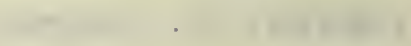

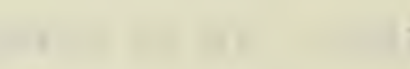

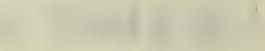

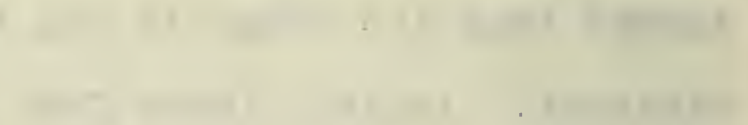
. 
vitellaria among distomes in general shows forms in which the vitellaria varies from a knob like gland on each side to forms in which the vitellaria surrounds the whole body under the integument except a median dorso-ventral apace. A typical type seems to by H-formed $a s$ is seen in 0 . lancea. It seems variation in the extent of the vitellaria comes by the degeneration of the glands ar one of the possible causes. I have noticed in few specimens of 0 . Viverrini, Clonorchis endmicus and Clonorchis sinensie that one or more acini are missing but the longitudinal duct is standing full of shell material. In other forms there were one or more acini below the transverse duct on one oide and in others on the other side. The general position of the transverse duct was constant, though the ducts coming from each group of acini vary considerably. In 0 . pseudofelinous the vitellaria has four possible combinationa both sides "V" shaped or "Y" shaped, right "V", left "Y" shaped or the reverse. The position of this transverse duct being constant, I find it is in the same place in both groups. Having all these variations and objections for the formation of a new genus Amphimerus, I find more argunent in favor of such a division than against it. The genus Metorchis is based chiefly on the extent of the vitellaria anterior to the acetabulum, the genus Clonorchis entirely on the dendritic testes. It is true that viteliaria ertent posteriad varies more than anteriad but er en so there is great contancy in this posterior extention. Among forms which form a homogeneous group 0 . obsequen $\mathrm{Nicoll}$ represents as much an intermediate form to the genus clonorchis as the variation in the extent of the vitellaria does in Opisthorchis. Thu the forms 0 . pseudofelineus, 0 . interruptus, 0 . lancea, 0. 


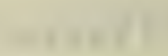

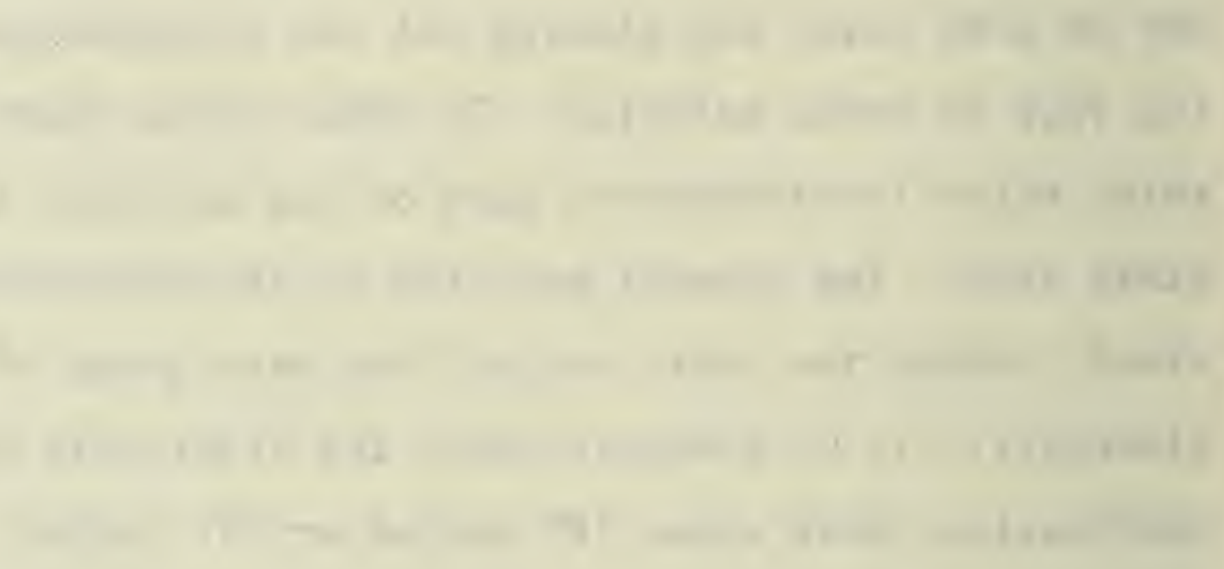


noverce, 0 . ovalis, and 0 . speciosus became Amphimerus pseudofelineus, Amphimerus interruptus, etc,.

Amphimerus pseudofelineus, A. ovalis and $A$. speciceus are the three American species very much alike. Barker (1911:520) makea a detalled comparison bosed chiefly upon measuremente som of them to tbatwa of a mioron. Some of these measurements are confusing sioce a great range of vatiation is represented. The oral sucker in A. ovalis varies from 0.198 to 0.36 in length and in width from 0.198 to $0.378 \mathrm{~mm}$, egg from 0.024 to $0.312 \mathrm{~mm}$ long by 0.014 to $0.019 \mathrm{~mm}$ wide. The mode of preservetion might be one of the causes of variation in measurements. I find the egg one of the most constant characters in 0 . viverrini, 0 . felineus and 0 . preudo-pelineus, there are some abnormal eggs which must be rejected in measuring. The topography of these three dmerican fo formo seem very much alike. Especially A. ovalis which is described as a now species chiefly because of the specificity of its host and some minor differences. Recently I have had for a tudy a single specimen colledted from Chrysemys marginata Agassiz taken near Falrport Iowa, which al though poorly preserved, corresponds to the description of Barker except that the uterine coils are more compact, as in A. spediosus. Some of these differences according to Barker go more in variance among the individuals of the same species than between the species themselfes. A. ovalis differs from the rest in its smeller size, the shape of the body being more slender, the oral sucker smaller, oesophagus larger, uterine coils more dense. Amphimerus specicaus has moro characters in common with $A$. preudofelineus than with $A$. oval1s; it differs however by the small size of the oral sucker, 


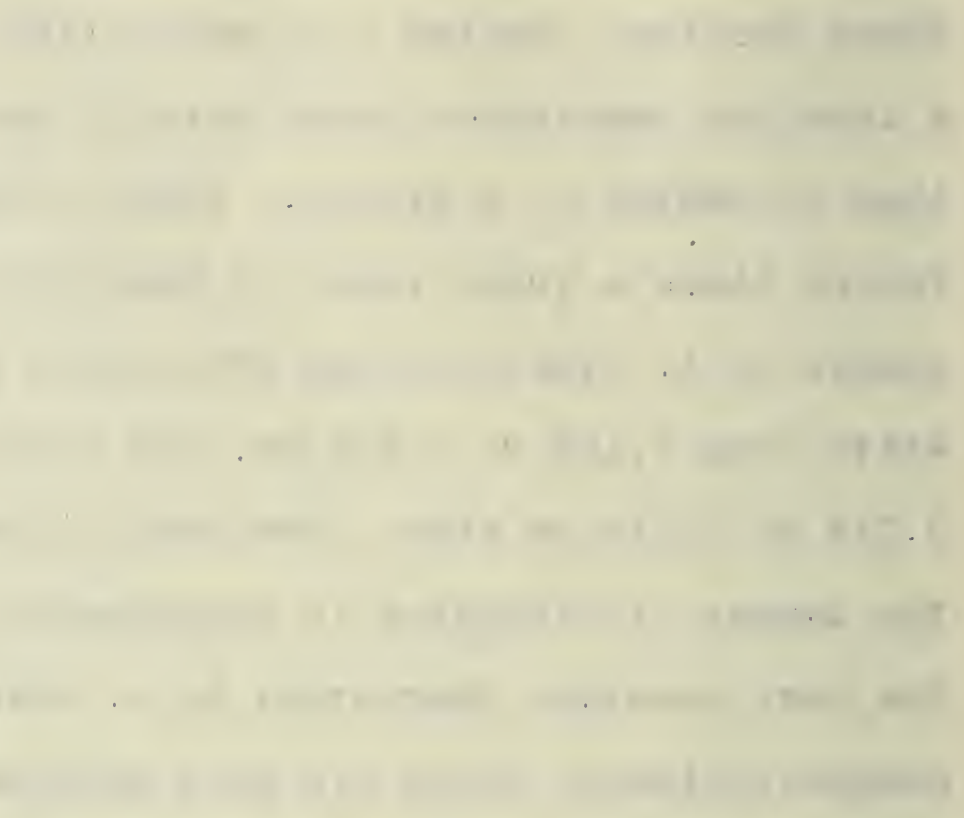

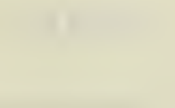




\section{$-35-$}

the position of the ovary (at the posterior fifth of the body) and its large size; by the more densty coiled uterus and by its avian host. A.ovalis in general is smaller than A. pseudofelineus and A. opeciosus ia more slender has omaller oral sucker, larger oesophagur, position of the ovary more anterior (posterior half of the body), less dense uterus coils and smaller egg, conotant oval shape of the ovary and testes and the reptilian host.

Amphimerus interruptus differs from the three American forms by its small size, 7 to $8 \mathrm{~mm}$, its lobed testes, smaller and elons egg, notably the difference in oize of the oral and ventral suckers the former being much larger.

A. noverca once 80 much confused in easily diatinguished from the above closely related forms by 1 to general form of body which is smaller and broader, its very pocrly developed uterine coils, its broad spinelets and the viteline glands which are indistinet.

MoConnell(1876:342) and $(1878: 476)$ found distomes in the biliary ducts of a Mohamedan, twenty elght yeara odd who died in the dical college of calcutta; and again in 1878 from another Mohamedan twenty four years old. McConnell diagnosed these forms as D. conjunctum Cobbold (1858). Lewis and Cunndrgham (1872:168) found in Pariah dogs in Caloutta, forms which they diagnosed as Distomum conjunctum. Stiles and Hassall (1894:430) showed that McConnell's form differed from that of Lewio and Cunningham. Loogs (1899:565) placed Cobbold's Distomum conjunctum from the Amorican red fos, Canis vulpis in the genus Metorohis. Eraun (1903: 164) gave to McConnell's form the name 0 . moverca. Barker (1911:532) placed that of Lewis and Cunningham in the 

genus Opisthorchis and named it 0 . caninus. Stephens (1912)

placed 0 . caninus in a separate genus; Parepisthorchis. This new genus is based upon the $0.5 \mathrm{~mm}$ pedicle upon which is situated the acetabulum and the genital pore. In all forms of the genus opisthorchis, the acetabulum is a cup shaped sessile adhesive organ sunken in the body parendhyma. In Paropishorchis hewever the acetabulum and the genital pore are on a pedicle which is retractile. Such a charaoter is a generde one. In all other respect the genus Paropisthorchis is like that of Opisthorchis.

Trom the above discussion one thing is clear; that is the need of experimental work to clear the specificity of many of these forms. I am inclined to think such a work will bring the identity of 0 . geminus, 0 . felineus, 0 . tenuicollis and 0 . entzi under one species. A. ovalds and A.speciosus in another. Such an experiment can be done as suggested by Lo088 (1899) by feeding experimental animals. Another thing that will do much in proving or diaproving the identity of these forms is careful search among hosts in question and a study of the life cycle in relation to the mode of transmission.

Key to the genera of the subfamily Opisthorchinae Lo088 1899.

(See page 2 for diagnosis of the subfamily)

1. (2) Vitellaria lateral to intestinal caeca - .. 3 2. \$5Vitellaria anterior to intestinal caeca, lateral to oesophagus uterine coils fill entire body posterior to acetabulum . . . . HOLOMETRA

3. \$2) Viteliaria not extending anteriorly beyond the ace tabulum . . . . . . . . . . 4 
4. Vitellaria extending anteriorly beyond the acetabulum

METORCHIS

5. (6) Vitellaria not divided into two distinct regiono by a break in the Iine of acini near the ovary - ?

6. (5) Vitellaria divided into two distinct regions by $a$ break in the Iine of acini near the ovary -

AMPHIMERUS

7. (8) Teater not dendritic $\ldots \ldots \ldots$

8. (7) Thates dendritic - . - . -

CLONORCHIS

9. (10) Acetebulum and genital pore on a pedicle

PAROPISTHORCH IS

10. (9) Acatebulum and genital pore not on a pedicle-

OP18THORCHIS

Key to the specior of the genus Amohimerus

Barker 1911

1. (2) Tester generally dibed - . . . . 3

2. (I) Tester generally simple, oval - A. ovalis

3. (4) Coils of the uterus moderately developed - 5

4. (3) Coils of the uterus well developed A. speciosus

5. (6) Number of acini in postovarial portion of vitellaria commonly four _ - . - . - . 9

6. (5) Number of acini in postovarial portion of vitellaria never more than three $\ldots \ldots$ ?

7. (8) A break in the Iine of acini moderate A. pseudofelineus

8. (7) Break in the line of acind indefinite

A. noverca

9. (10) Postovarial acini very marked - A. interruptus 

10. (9) Broak in the line of acini moderate A. landea Key to the species of the genus Opisthorchis

1. (2) Body spineless _. $\ldots \ldots$

2. (1) Body covered with spines - - - - piscicola

3. (a) Suckers unequal, uterus well developed - 5

4. (3) Suckers equal uterus poorly developed

\section{0. viverrini}

5. (6) Ovary not multilobed _........ 9

6. (5) Ovary multilobed …........ 7

7. Oral aucker larger than acetabulum 0 . aimulane

8. Oral sucker smaller than acetabulum

0. Iongisaimus

9. (5) (12) Oral sucker smaller than the acetabulum- -10 10. (11) Found in the liver of Mammals - 0. tenuicollis 11. (10) Found in the liver of birda - 0. entzt 12. (5) (9) Oral sucker larger than the acetabulum - 23 13. (14) Found in the liver of Mammala - -

0. felineus

14 (13) Found in the Iiver of Birds - 0. geminus. 



\section{DESCRIPTION OF OPISTYORCHIS VIVERRINI}

\section{POIRIER 1886 TAR. CHIENGMAI}

The ganeral diagnosis - This parasite is lesf shaped, oblanceolete flattened dorso-ventrally. The preserved specimeno are almost traneparent, uterus region somewhat dark and always full of the numerous yellowish tinged egga; the body has many ridges mostly passing transversly on account of the contraction. The integument is roughened by rubbing. The anterior third of the body atarting at the acetabuium gradually tepers and is almost conical at the anterior end. At the legel of the acetabulum on both sides of the body there is a slight shallow constriction whioh distinguishes a neck region. Posteriot to the acet abulum the lateral borders run fairly parallel until to the posterior testis, from there it gradually decreases in width till at the extreme posterior end it tapers bluntly. The length and breadth vary according to the contraction and normal individual variation. The length varies from 2.7 to $7.7 \mathrm{~mm}$. Two specimens are $6 \mathrm{~mm}$ in length, two 5 , throe $5.4 \mathrm{~mm}$; four $4.6 \mathrm{~mm}$. The average length of twenty specimens is $5.3 \mathrm{~mm}$.

Width and thickness varles from 1 to 1.3 and 0.23 to $0.44 \mathrm{~mm}$ respectively. The suckers are about $2 / 7$ of the length of the body distant frorn each other. The variation is largely due to the expansion of the cephalic tegion at time of fixation. The euckers are about equal aize 19 by $22.4 \mathrm{~mm}$. The length of the oral sucker varies considerably from 0.125 to $0.23 \mathrm{~mm}$. The widh from 0.17 to $0.25 \mathrm{~mm}$ and 0.19 to $0.27 \mathrm{~mm}$ respectively. The acet abulum measures 22.5 by $23 \mathrm{~mm}$. The osslphagus is much longer 

than the pharynx, the former $0.31 \mathrm{~mm}$ on the average varying from 0.34 to $0.42 \mathrm{~mm}$, the latter 0.14 by $0.13 \mathrm{~mm}$. The intestinal crura reach almost to the posterior border and are often filled with bldod. The excretory pore is at the posterior extremity and the excretory bladder curves between the testes in an S-shape. The tester are located at the posterior, approximately $2 / 7$ of the body length from that end. They lis obliquely one behind the other; the anterior one has four lobea, the posterior one five. The ovary is multilobed with smooth margin; it occupies the anterior part of the posterior $\frac{1}{4}$ of the body (average) alightly toward the right (0.08) from the median. Behind the ovary lies the pear-ahaped or ratort-shaped seminal receptacule. Laurer's canal present. The uterus colls occupy a median posttion in the midale third of the body. The vitellaria occupy the faity broad lateral areas, in about the midile five, six and seven and a half tenth's of the body. The number of acini varies from 7 to 9 usually 8 on each side. It never passes posteriorly beyond the anterior margin of the first testis nor reaches to the acetabulum. Cirrue poach absent. The eggs are oblique oval with a round operculum at the aharper end 0.026 by $0.0156 \mathrm{~mm}$. There is a distinct narrowing towards the anterior end, a distince lid followed by a shapply projecting brim as in clonorchis sinensia.

Habitat - Liver.

Host - Indian civet cat, first time recorded from man in Siam 1915

I included the above short description in order to give a general ides of the form; but it seems to me that minor details 


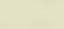

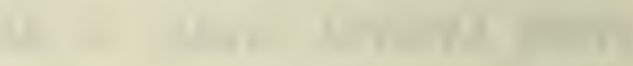
+

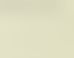

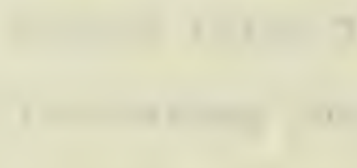

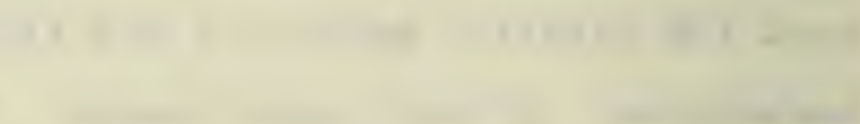
. 
need to be mentioned though some of them are in considerable variance, for easy diagnosis by later workers with the samo kind of forms. All present confusions would have been eliminated if former investigators had given a detailed description of this form The oral opeting of 0 . viverrind var. Chiengmad do nearly clrcular in transverae section, terminal and surrounder by the anterior sucker. The thiokness of the oral sucker is about $0.13 \mathrm{~mm}$ Behind this there is a small pooket immediately followed by a circular pharynx 0.41 by $0.13 \mathrm{~mm}$. The length varying from 0.13 to $0.15 \mathrm{~mm}$, width constant. The length of the oesophagus in some cases is three times as much as the pharynx but this region is much at mariance; from 0.24 to $0.42 \mathrm{~mm}$ with an average of $0.31 \mathrm{~mm}$. At the base of the oesophagus there is an enlaggment before the bifurcation takes place. The intestinal crura extends between the uterine coils and vitellaria nearly to the posterior end of the body. Usually both end at the same level. Sonetimes the tight or left extanding further. The average dibtance from the posteidor end to the end of the orura is $0.25 \mathrm{~mm}$, varying from 0.11 to 0.4 mm.

The female reproductive organs are composed of multilobed ovary, the vitellaria on both sides of the margin with a trangverse duct. The shell glands are composed of isolated cells opert ing into the ootype. The uterine coils dorso-ventrally and right to left in front of the ovary, and opens into the common genital pore immediatly anterior to the acetabulum.

The vitellaria occupies a media postion of the body from 0.03 to $0.13 \mathrm{~mm}$ from the body margin on both sides. The number of acini is regularly 8 on each side though it varies from 7 to 9 the extra one usually being on the right side. The right vitelialo 

is larger than the left, it starts $0.38 \mathrm{~mm}$ from the posterior end of the acetabulum on the average. The closest it extends anteriorly to the posterior end of the acetabulum is $0.24 \mathrm{~mm}$, the fartherest $0.9 \mathrm{~mm}$. The left vitellaria $0.42 \mathrm{~mm}$ behind the acetabulum on the average varying from 0.3 to $0.84 \mathrm{~mm}$. The range of extent of the vitellaria posteriorly varies little. It never extends behind the anterior testis more than 0.4 to $1 \mathrm{~mm}$ on the right, 0.42 to 0.06 on the left. Taking the ovary for the comparison of vitellaria extent it is 0.06 to $0.42 \mathrm{~mm}$ below the anterior end of the ovary averaging $0.2 \mathrm{~mm}$. Each acinus is connected by curved longitudinal ducts on each aide. Later this duct unites with the trangverse duct forming a broad $V$-shaped figure. The upper duct unites with a duct coming from the lower acini in front of the viteline glands the united duct forms the teansverae duct. The same kind of union takes place from the left viteliaria but not always in regular manner as soretines the union from the upper and wower duct takes place between or afte they leave the glands.

The shell glands are somethat diffused on both sides of the ovary and in front where the uterue begins. They are single isolated cells scatered in the parenchyma. They open into the ootype which is alitte above the region where the vitelline duct opens in to the uterus.

The ovary is multilobed, ita margin smooth slightly toward the right $(0.44 \mathrm{~mm}$ from the right side of the body $0.52 \mathrm{~mm}$ from the left). It oocupies the anterior part of the posterior onefourth of the body. The average width of the ovary is 0.46 and the length $0.22 \mathrm{~mm}$ varying from 0.34 to $0.57 \mathrm{~mm}$ by 0.19 to $0.29 \mathrm{~mm}$ 


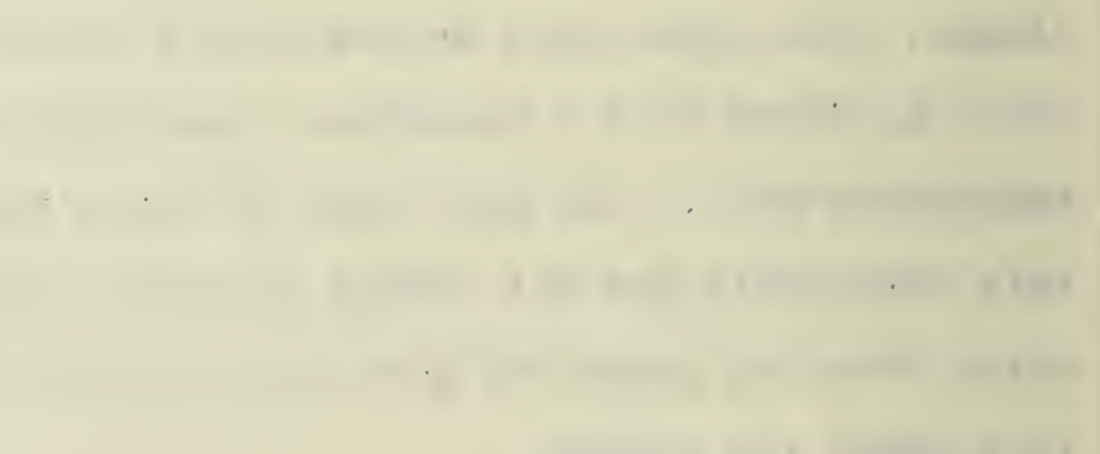


respectively. The number of distinct overy lobes varies considerably from 3 to 9. Some of the 10 bes are much larger than others There is alwahs a regularity in having two branches, a right and a left one on each side of the receptaculum suminis resembling a saddle. The ovary is more antero-ventral to the receptaculum seminis and the lobes have three diredtions, right, left and median. In 80 per cent of the specimens examined the right and left lobes are equal. The oviduct opens into the uterus below the vit elline duct. Just above the common branch of Laurer's canal and the recepteculum seminis. The uterine coils occupe a median position in the middie $1 / 3$ of the body. The uterus is filled with ature yellowioh egge. The lower end unites with the ootype and is mostly filled by spermatozoa. The genital pore is immediately anterior and median to the acetabulum, it is sometimes slightly toward right or left. The uterus opens in the common genital atrium by the side of the vas deferens.

The vas deferens colls from the right side and opens into the common atrium at the side of the female genital pore. The vasa efferentia coming from each testia unite between the uterine coile and form the vas deferens. The two teater are placed obliquely one behind the other. The anterior testis lo fonn lobed, the posterior five lobed. The lobse are not always regular. From twenty specimens only one anterior teatia had three lobes, in three the lobes were poorly developed the rest were well developed. There is greater irregularity of the posteriob testia than the anterior one. In three specimens there was only four lobea, in another three, four others had five dobes but one br two of these were very poorly developed. The anterior testis 

is more to the left side of the body, the posterior more median and somewhat inclined toward the right. Both teates are elsvated from the level of the body and occupy moat of the dorso-ventral space. The anterior testis is located in the 6 th or 7 th posterlor tenth of the body at the posterior $2 / 7$ of the body. Ita length varies from 0.19 to $0.48 \mathrm{~mm}$. The average $0.34 \mathrm{~mm}$. The width from 0.22 to $0.48 \mathrm{~mm}$. The average $0.33 \mathrm{~mm}$, the length and widh of the posterior testis is 0.36 by $0.47 \mathrm{~mm}$, varying from 0.19 to $0.48 \mathrm{~mm}$ in length and 0.27 to $0.48 \mathrm{~mm}$ in width. There is a marked regularity in the position of the lobes, the anterior testis has four lober and in 80 per cent of the cases these lobes are arranged right, let anterior and posterior. The posterior testis has five lobes and the are arranged anterior right, anterior left, right, left and posterior in 60 percert of the casss. In 20 per cent of the cases for anterior testis the endency was anterior right, anterior left, posterior right and posterior left. In 30 per cent of posterior teatis the tendency was anterlor, anterior right, anterfor left, posterior right, posterior left, in the rest of 10 per cent irregular.

The seminal receptacule is of medium aize, pear or retortshape and dorsal to the ovary; in all cases filled with spermatozoa. Laurer's canal starts from the common duct into which the receptaculum seminis opens and extends downwara, curves backward, then to the right making a larger diameter to the tube, then it nuns straight downward and opens on the dorsal surface of the body on the dorso-lateral aled of the receptaculum seminis.

The excretory bladder is located in the posterior fourth of the body. It stats a little behind and lateral to the recept- 
aculum seminis and latero-posterior to the ovary. It curves between the testes in an S-shape then enlarges greatly in diameter forming a buld behind the posterior testis, it then narrows conclerably and opens to the outside thru a narrow slit. The diameter at its anterior portion is about $0.48 \mathrm{~mm}$, between the testes $0.23 \mathrm{~mm}$, at the bulb region $0.4 \mathrm{~mm}$ at the narrow nedk $0.15 \mathrm{~mm}$, and at the pore $0.01 \mathrm{~mm}$. These figurea vary considerably.

The reproductive syotem - The genital pors openo immediately anterior to the acetabulum 0.008 to $0.018 \mathrm{~mm}$. Mostly median though in some cares slightly to the right or left. The genital closca is about $0.07 \mathrm{~mm}$ long. The cloaca is flask shaped. The metraterm, the terminal portion of the uterus, has the same diameter as the cloaca at this region which is a continuation of the first. The ductus ejaoulatorus narrows into a vary narrow opening about one-half to one-third the size of the metraterm opening and at the side of it. The genital cloace gradually narrows like the neck of a bottle. The genital pore opens at the level of the anterfor of the acetabulum on the mentral side which is raised from the general level of the body. The wall of the cloaca is surrounded by heąve muscular annular muscles. Numerous prostate glands are located around the genital pore and open into it.

The vas deferens is filled with spermatozoa. It curves with the uterus side by side dorsally and opens in the genital cloaca $0.06 \mathrm{~mm}$ from the ventral eurface or frow the genital pore. The vas forens starts from the anterior testis on the inner surface of the anterior lobe about $0.05 \mathrm{~mm}$ from the doral surface, it curves slightly above the testes and curves in at the shell gland pasing between Laurer's canal and the intestinal crura and 

under the transveree vitelline duct. The other vas efferens starta from the inner anterior right lobe of the posterior teatio and joing the firat at about $0.38 \mathrm{~mm}$ fron the genital pore forming the vas deferens. The diameter of the vasa efferentia is about $0.01 \mathrm{~mm}$ the diameter of the vas deferens varies from $0.06 \mathrm{~b}$ $0.12 \mathrm{~mm}$. The vasa efferentia unite between the uterine colls slightly $(0.09 \mathrm{~mm})$ dorsal to the median portion of the body. The vas defereng aurves dentrally at the anterior margin of the acetabulum toward the doraal gide of the acetabulum. At the postero-dorsal region of the acetabulum it co1ls up till the posterior $1 / 3$ of the acetabulum. Then it curves to the right on the same level and makes seven dorso-ventral loops before it reaches the vas efferens. The loops are situated onthe right on the ame level from the median longitudinal plane of the acetabulum. The loops are found in two regions ane to the extreme right and the other more to the posterior. The extreme right loops aro proximal to the acetrbulum, they coil dorso-ventrally much more and are larger in diameter. The colls comeing from the posterior of the acetabulum bend toward the right at about the same long thdinal plane with the lateral right margin of the acetabulum then coila dorsally. From there a short continuation to the posterior and to the right at that point it curves to the ventral surface then makes a short transverse landing. The last two colls are short and at the same level as the provious one. The posterior part of the vas deferend is straight and at the same level as the extreme left extention of the anterior collo.

The testes ars obliquely placed on the posterior $2 / 7$ of the body(average). The anterior testio more on the left and the 


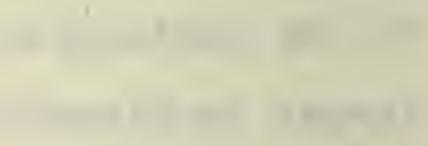

10

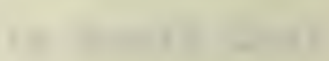




\section{$-47-$}

posterior more median or alightly toward the right. The lobea are short with round smooth margins. They originate from a common center. The length of the testes'lobes vary from 0.095 to $0.15 \mathrm{~mm}$ The median portion of the testes filling nearly the corso-ventral space at this region and are olightly closer to the doral than to the ventral surface.

The female reproductive syatem - The vitellaria occupies the lateral borders between the margins of the body and the intestinal cunra. The vitellaria never extend cephalad to the acetabulum nor caudad. Only in two casea do the viteliaria extend to the anterior margin of the anterior testis. The vitellaria do not quite occupy the middle $1 / 3$ of the body margin. The mean relation in twenty speoimens examined gave $0.42 \mathrm{~mm}$ anterior non-vitellaria portion, $0.34 \mathrm{~mm}$ median non vitollaria portion and $0.34 \mathrm{~mm}$ postorior non vitellaria portion. This ratio is in condiderable variance in some individuala as the anterlor portion extends some what in fixation.

The vitellind glands are oval or apharloal, tranoveraly placed in the parenchyma. A longitudinal duct from both vitellaria having ducts opeing from each gland and later the two longitudinal ducts joined by a transverse vitelline duct which bends obliquely to the ovary and slightly toward the left of it enlarges forming the vitelline reservoir. In sefenteen out of twenty specimens, the right vitellaria has 8 acini, 8 opecimens show only 7,16 have 8 acins on the left, two have 9 and another pair have 7 acind. At the beginning of the transverse duct, the longitudinal duct ooming from the anterior and the one coming form the posterior form a long Y-shaped figure. On the right in 
- n

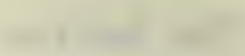

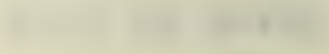

20150

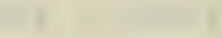

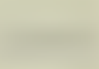

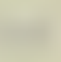

$+2$

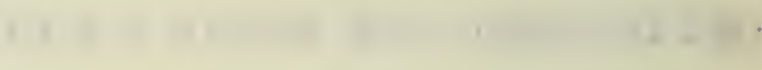

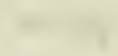

$\left(\frac{10}{2}\right.$

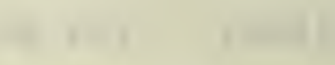

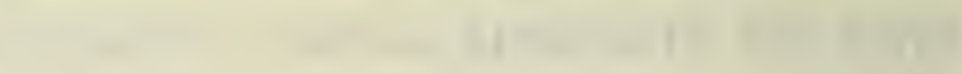

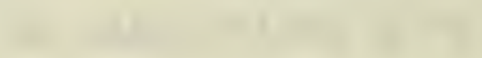

10

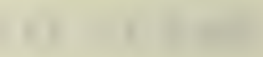

10

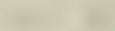
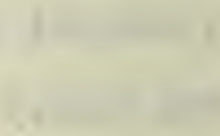

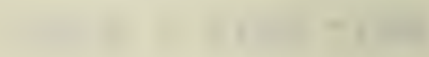


suven forms the union is among the glands, in the reat 0.038 to $0.057 \mathrm{~mm}$. toward the ovary. On the left in 9 form the union of the ducts is at the glands, the rest from 0.006 to $0.057 \mathrm{~mm}$ toward the ovary. In aix forms the right ecini were entirely distinot; on the left in one form siven acini were in combination, in two 5 acini and in three only two acini were in combination. In three apecimes only three acini are in combiation on the right. The space between the acini varies considerably but at a small margin from $0 ; 05$ to $0.12 \mathrm{~mm}$ the average being $0.09 \mathrm{~mm}$. In six forms the number of acini posterior to the transverse duct on the right was tho, the rest, one in the same region. On the left eight specimens have two aoini the rembinder having one. There is no break between anterior and posterior part.

The course of tle longitudinal vitelline duct is at the inner margin of the glands median to dorso-ventral surface. Between the spaces of acini it curves toward the intestinal orura, the concave side being toward the glands. The width of the acini varieg from 0.09 to $0.1 \mathrm{~mm}$ the length from 0.12 to $0.35 \mathrm{~mm}$. In one case only an entire acinus was degenerated.

The transverse duct passes dorally to intestinal crura. The transverse duct from both sides unites between the ovary and the seminal receptacle olightly toward the right. Branched efferent ducts from these groups of cello unite with the longttudinal ducto and these later with the tranoverse.

The vitellaria consiats of numerous oblique oval, elliptical lobes with smooth rounded margins. In some species the lobes are very closely aggreguted in others more or lesg distinct. Each lobe is surrounded by a thin menibrane. The lobes are held 



\section{$-49-$}

in the parenchyme. They contain numerous cells of sheil forming material. These cells are mostly spherical and contain numerous yellow granules. There is a vesicular nucleus well stained with Erlich's acic hematoxylin. It has a distinct nucleolus and a number of chromatin granules.

The itelline reservoix is on the left oide of the ovary below the shell glands. The unpalred duct originates from the ventral anterior side of the vitelline reservoir. At the proximal end it proceeds anteriorly having a diameter of $0.018 \mathrm{~mm}$ at the diatal and, where it opens into the common duct $0.04 \mathrm{~mm}$ in diameter The unpaired duct opens behind the ootype, at this point it has a diameter of $0.06 \mathrm{~mm}$. This measurement varies according to the amount of yolk found in the ducts. The thickness of the viteline reservoir is $0.045 \mathrm{~mm}$. It is formed by the expansion of the transverse duct in this region. The teangeorse duct continues dorsally while the unpaired duct below this proceeds at right angles to the transverse duct and anteriorly toward the ootype. This unpaired.duot is in a plane 0.02 mentral to that of the transverse duct. The walla of the duct are homogedeaus, no aucleus is seen. The thickness of the duct alls 1 s $0.003 \mathrm{~mm}$. The ovary is multilobed and has a smooth margin. It occupies an anterior lateral and slightly antero-ventral position to the receptaculum seminis. The average length is $22 \mathrm{~mm}$ and the width $0.45 \mathrm{~mm}$. The thickness varies according to the different 10bes. The antero-ventral lobes are thickest $0.2 \mathrm{~mm}$ the others $0.12 \mathrm{~mm}$. The oviduct preceeds anteriorly $0.01 \mathrm{~mm}$ to the right from the starting point where it jions the common duot behind the unpaired vitelline duct. The length of the oviduct is $0.36 \mathrm{~mm}$. 
It is $0.072 \mathrm{~mm}$ ventral to the receptaculum seminis. The duct coming from the receptaculum seminis and Laurer's canal curves making a small arch above the Receptaculum seminis, then forma a trough and begins to run straight anteriorly joining the oviduct. The ootype is at the posterior end of the uterus and is a slight enlargement in the diameter of the uterus. In the ootype the shell glands pour thetr yolk and there fertillzation of the egg takes place by the spermatozoa which pass from the receptaculum seminie uterinum into this region. The ootype is $0.12 \mathrm{~mm}$ from the ventral surface and 0.23 from the dorsal, its thicknoss 0.012 $\mathrm{mm}$ on the average. Its distance from the receptaculum seminis is $0.072 \mathrm{~mm}$. The walls have thich annular muscles. They have nuc1eated cells. The lower part of the ootype il covered on the inside by cilia.

The eggs are oblique oval from a hundred measurements taken from twenty five specimens, four from each, sixty per cent gave $25 \mathrm{u}$ for length and $15.6 \mathrm{u}$ for width. In ninety-fuve per cent the maximum length was thehty-eight $u$ and the remalning five per cent twenty-seven $u$, the rest $23.4 \mathrm{u}$ the minimum length. The minimum width is $13 \mathrm{u}$ and $a$ width of $15.6 \mathrm{u}$. The width is more constat than the length. Laurar's canal from the upper doral side of the recepteculum seminis curves to the left oide, takes a poateriorly couree dorally over the left lobe of the ovary., $0.18 \mathrm{~mm}$ below the receptaculum seminis. From there it pases from a dorsal to a ventral course by that making a curve anterior to the exoretory bladder. Then 1t makes a slight curve and opens on the dorgal surface $0.054 \mathrm{~mm}$ from the excretory bladder. The diameter of the opening is $0.024 \mathrm{~mm}$. The longest diameter 0.04 
mm at the turning point from the ventral to dorsal surface. The diatance from the origin to the dorsal opening is about $0.3 \mathrm{~mm}$ bint the actual length is much larger as it curves much in its course. The walls of the canal is surrounded by circular muedes and cilia on the upper inner fortion. At the opening to the ott side there are glands opening into the canal. These appear to be degenerate prostate glands. The tends to show that Laurer's canal is a vertigial vagina.

Seminal receptacle is pear or retort shape. The length varies from 0.3 to $0.6 \mathrm{~mm}$, the width from 0.18 to $0.26 \mathrm{~mm}$, while the thickness varies from 0.2 to $0.27 \mathrm{~mm}$. The receptaculum seminis lands from a median position toward the right side of the body in few specimens on the left and in one median. The anterior end is between the ovary lobes, the posterior part of tt behind the ovary. The seminal receptacle is somewhat more toward the doraal aurface. The wallo are non-nucleated. The sac-like cavity is filled with spermatozoa. The anterior end of the receptaculum seminin is tepering and pery narrow abouto.018 mm. The Laurer's canal makes a junction at the anterior end. From this junction $0.06 \mathrm{~mm}$ on the left side is the vitelline reservoir. The oviduct opens just anterior to the Laurer's cans junction.

The uterus coils above anteriorly and to the right from the ootype and curves dorsally from this point to the cotype. There are no eggs in this portion which is however filled with spermetozoa. The uterus above the ootype is $0.024 \mathrm{~mm}$ in diameter. The uterine coils occupy nearly the middle $1 / 3$ of the body. They are filledwith yellowish eggs. The coils do not extend over the intestinal crura. The number of coils in different individuals 


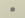

a

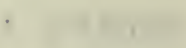


does not differ; the difference lies in the extent and the magnitude of the coils. In the logg expanded individuals the coils are looser but in amalier and more contracted forms much more compact. From the metraterm the uterus prolongs dorsally and anteriorly to the left of the acetabulum at the lower margin of which it ourves ventrally. It extends $0.036 \mathrm{~mm}$ posteriorly and coils dorarly and preceeds toward the right transversly making a dorso-ventral 10op. From there it bends ventrally then dorsally passing transversly between the two crura which I call the firot group. The margins of these loons are $0.12 \mathrm{~mm}$ from the left crus and $0.06 \mathrm{~mm}$ from the right respectively. The second group exterds more toward the lateral crura, the left margin $0.18 \mathrm{~mm}$, the right $0.036 \mathrm{~mm}$. This group is formed by a transverse loop formed by the coiling of the iterus toward the left ventrally and toward the right dorsally. There are twenty-three ouch groups formed by the coiling of the uterus dorso-ventrally and tranevereoly. Some of them are short and medium in size while others extend from one crue to the other.

The shell glands are single isolated cells scatered in the parenchyma anterior and anteco-;ateral to the ovary extending up to the uterus. They open into we ootype. Thoir secretions aro known to be at present not shell material but yolk. The glands start nearly at the same plane as the ovary which is more ventral

The edcretory system - The excretcry bladder occuples the posterior fourth of the body on an average varying from $1 / 3.3$ to $1 / 4.6$. The general shape is that of an $S$. The testes are located in the concere opaces. The bladder is well developed and oocupies almost the dorso-ventral spece except at the excretory 



\section{$-53-$}

pore region, and the testes region $2 / 3$ to $4 / 5$ of the body thicknes is occupied by the biadder. This must vary as in preserved specimens in most cases the excretory bladder is greatly contracted. Below the posterior testio the excretory bladder increases freatly in diameter becoming a circular bulb about $0.38 \mathrm{~mm}$ in diameter. There it narrows into a slit of $0.009 \mathrm{~mm}$ at the opening to the outside. The pore is pesterior at the blunt tapering end of the boay, the length of narrow slit is 0.05 to $0.07 \mathrm{~mm}$. The shape of the excretory bladder in larval forms is etraight but as the growing proceeds adjacent otgans, the testes, expand and push the bladder aside to make more room for themselves cousing it to take an $S$ shape, the present form as was suggested by Ward. The forthing of the anterior end in the genus opisthorchis might be due to the same cause, that is to the growth of the ovary posteriorly.

There are three kinds of excretory ducts, two main ducto, one on each side of the body which carry waste material to the excretory bladder. One secondary duct unite日 with the main duot at the level behind the acetabulum the other at the front of the ovarial region. A branch comes fram the posterior region of the body. A third kind of branohes unite to the main and the secondary. These tubules terminate in flame delle. On account of the poorly preserved specimens I have not been able to follow every tubule. I have been able to aee the flame cello in section. They measure 1 to 1.1 micra. The ducts and tubules are symetrical on both sides of the body. The right main duct opens into the excretory bladder anterior to the posterior testis and the left $0.32 \mathrm{~mm}$ above the right branch. The main ducts have a very 

wavy course between the intestinal crura and vitelline glands. The alimentary system - The opening leading from the oral sucker into the pharynx measures 0.04 to $0.57 \mathrm{~mm}$ in diameter. The pharynx becomes somewhat larger in diameter toward the outer margin of the sucker. The oral opening is terminal, continued inside by the thinner cuticula. Behind the oral sucker there is a Iitte pooket 0.048 to $0.076 \mathrm{~mm}$ in diameter Iined by a thin lamelia. The pocket is somewhat funnel shaped. Behind tho pocket is more elliptical than the circular pharynx. The walla of the pharyna are much thinner dorso-ventrally than laterally so the phafynx has a verticle poit appearance when focused upon in the doreo-ventral position. The thickness of the pharynx is the same as the width. The inner lining of the pharynx consists of thin cuticula 0.0013 to $0.0026 \mathrm{~mm}$ in thickness. The opening of the oesophagus to the pharynx is much wider, about $0.047 \mathrm{~mm}$ varying from 0.036 to $0.092 \mathrm{~mm}$. The owsophagus runo $0.03 \mathrm{~mm}$ ventrally to the midale Iine. It gradualiy increases in thickness and width $0.057 \mathrm{~mm}$. The anterjor end $\$ 8$ circular gradually taking an elliptical form, the major axda bolng right to left. The aterage width of the bifurcation is $0.19 \mathrm{~mm}$. These flgures vary greatly according to the degree of contrection of the specimen at the time of fixation. The ovsophagus has an inner homogeneous layer varying in thickness from 0.006 to $0.012 \mathrm{~mm}$. The layer is aurrounded on the outside by circular and iongitudinal fibers. There is no columnar epithelial cella at the bifurcation and the oesophagur regions. The intestinal crure are lined with columnar epithelial celle which are embedded in narrow elongatecelis with nuclei. 

The crura prolong posteriorly at first more median from dorso-lateral surface and gradually bend to the dorsal 0.06 to $0.08 \mathrm{~mm}$. They curve in their course right to left more than dorso-ventraliy, but the later ones are greater in extent. It does not overtop the uterine coils but takes a course between the later and viteling glands. It forms a trough in front of the testes and a crest above. The same hapens at the reoptaaulum seminis due to the gtowth of the these organs they push the caeas to one side. At the posterior end the cuura bend alightly toward the median Iine of the body which is occupied by the excretory bladder. The crura in cross section are seen to be circular at the anterior region and somewhat irregular at the tering and posteroor regions. This con be expected as the uterus fills with eggs and consequently pushes the crura to one side, while tho anterior region will be left normal. The crura end blindly nearly to the posterior end of the body. Generally both branches edd at the ame level 0.21 to $0.4 \mathrm{~mm}$ from the posterior end of the body $0.25 \mathrm{~mm}$ being the average. Sometimes the right or left extends olightly further. The length of the crura if straight would reach to the posterior end. The crura are alwayg full of blood which shows that the parasite lives upon the blood of the host.

The cuticula - The body is covered by a non nucleated layer the thickness of which varies in different regions of the body. It being thicker at the oral end and around the ventral sucker. The pharynx, the oral sucker, the ventral acetabulum, the genital and the excretory pores are lined with a thin cuticular layer. A portion of the cuticula atains more intensely than the other, the deeper stained portion with Erlich's acid hematoxylin is the 
,
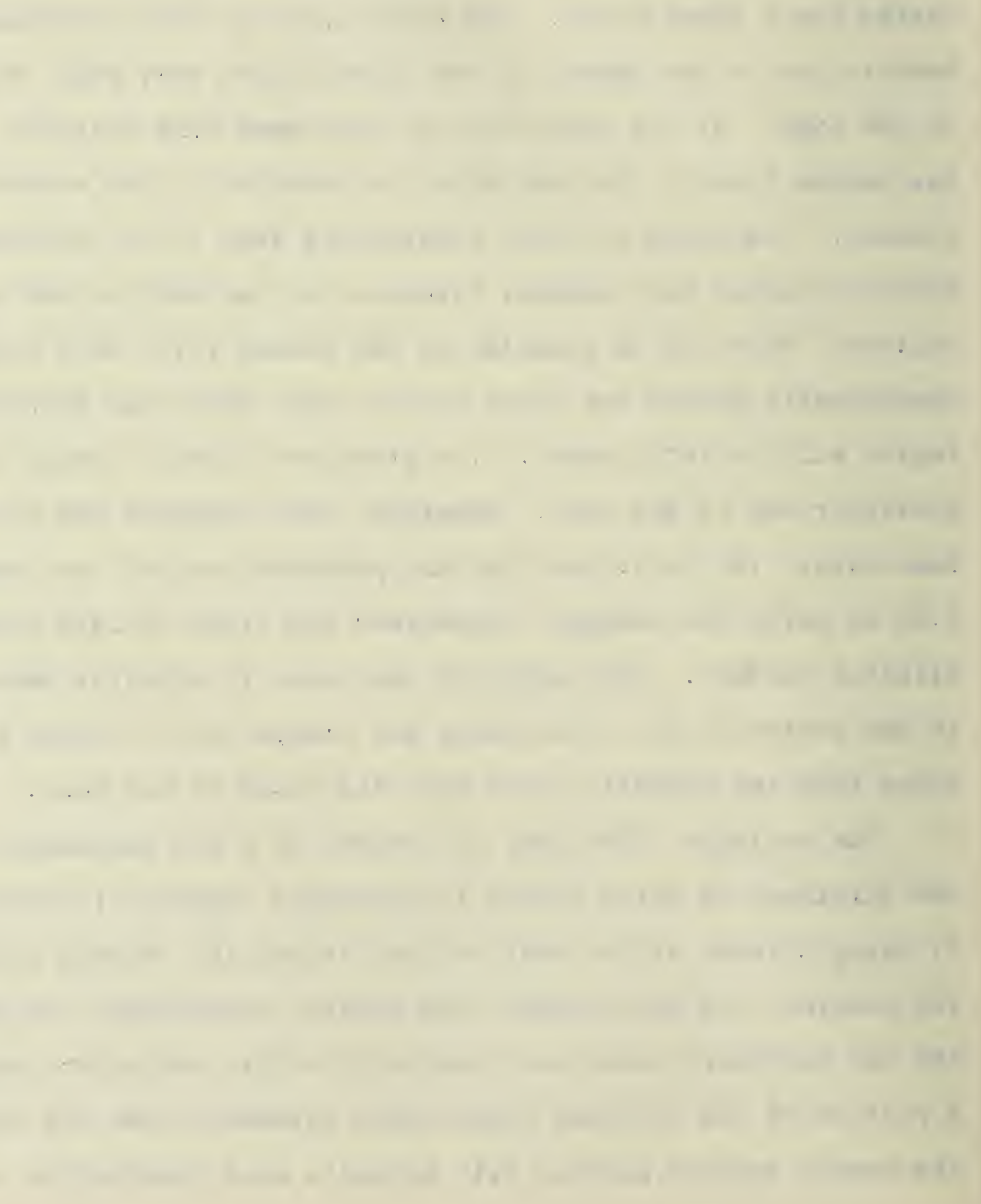
outside layer and the leseer atained portion inside called by some the besement membrane. There are four different kinds of opinions as regards the origin of the cuticula. I would not attempt to bring all their argunents but will only mention them. The coverings of the invertebratos is in general a true cutiche. Some authors think Tremadodes and Cestodes have a cuticule secreted by the hopodermis which means morphologically that it is a true cuticula(Blochmann 1896). According to this theory epithelial celis are sunken into the parenchyma and connected to the cuticula by long projections.

A second yiow was that of Brander (1892). He thinks the cuticula is secreted by the subcuticular single cella derived frem the parenchuma and joined by ducto to the cuticula passing between the superficial fibers. Tennent (1906) adopted Brandes view.

I third theory is that epitholium(ectoderm) metamorphosed into cuticula. Wagnex (1855). Some of the authors supporting this view are Monticelli, Goto, Nickerson and once by Braun. Schwara working with cercariae and Zeller with Polystomum noticed that epitheldal cella have their nuclei merely shrivelied.

Another theory originated by Leuckart(1886;367) is that after the disappearance of the epithelium the parenchyma portione solidify in the peripheral regions by secretion of the cuticular substance from the whole body of the parenchyma. Looss (1893, 1894) Braun (1893:818) Bratt $(1898,1899)$ and Young (1908) conf1rm this in there observations. Those who hold this view have various explanations to the possible function of the subcuticular cells. Pratt suggested they secret some kind of pretective substance against injurious products of the parasite. Looss and 



\section{$-57-$}

Leuckart regard them as connective tissue structures which give $r$ is to parenchyma cells. Laos compares it to the combium of plants. By my atudy of this form I am convinced that libe cuticula is formed as described by Young(1908:193) who worked with Cyetocercus pdaiformis. His vier is identical to that of Leuclart. Quoting him "The cuticula of Cyoticercus pisiformis is developed from a ground of simple parenchyma fibrillae by a deposition among them of a cement substance. There are no specialized fibrillae or cellular processes concerned in its development". I have seen those simple parenchyma fibrillae in the outioula in different parts of the same section. I have seen it to be a continuation of the parenchyma fibrillae.

The parenchyma is formed of this strands of connective tissue enclosing large vacuolated spaces. Between the fibrous not work there are small nuclei. All the body carity is filled with these parenchyma cells. The parenchyma celis near the circular muscles are much smaller. It is the corticel layer of the ecto-parenchyma of Brandes (1892)

In the parenchyma there are numerous giant cells few in the pharynx and sucker muscles. These cells have many branchos at each side two rain branches coming from the central portion having the form of an epitheliab cell nucleue. Each branch divides into main branches and extends to the longitudinal muscles, these cells are Nicoll's myoblast, ganglion cells of Looss. There are few of the same kind of cells as myoblast except the various branches radiate from the common cinter and each radiating branch divides into fine fibers. They also extend to the longitudinal muscles. These are called giant parenchyma cells. 

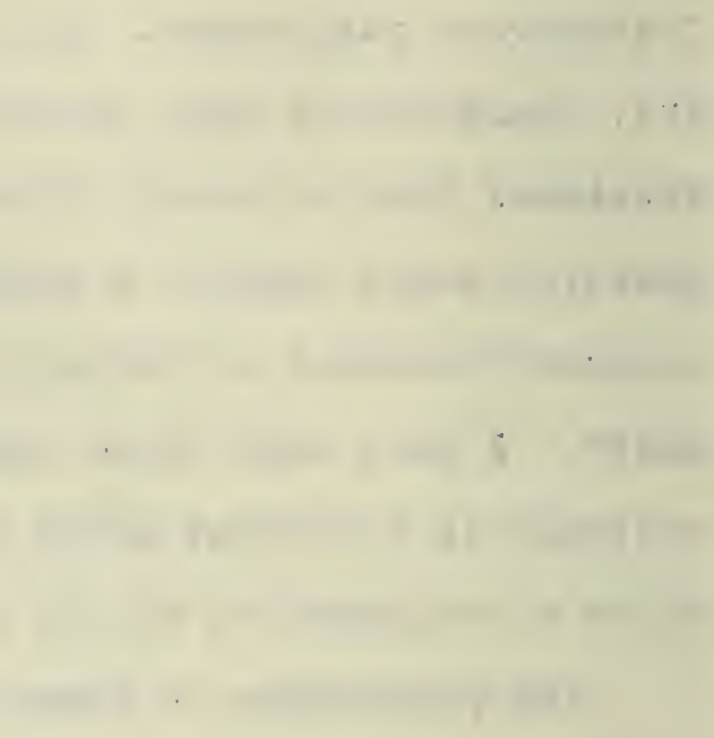

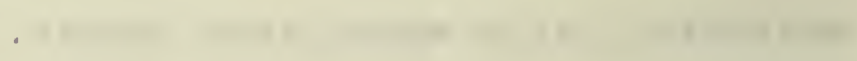

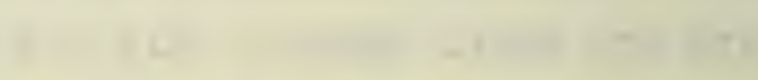

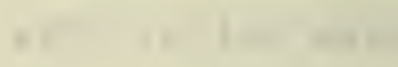

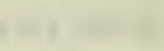
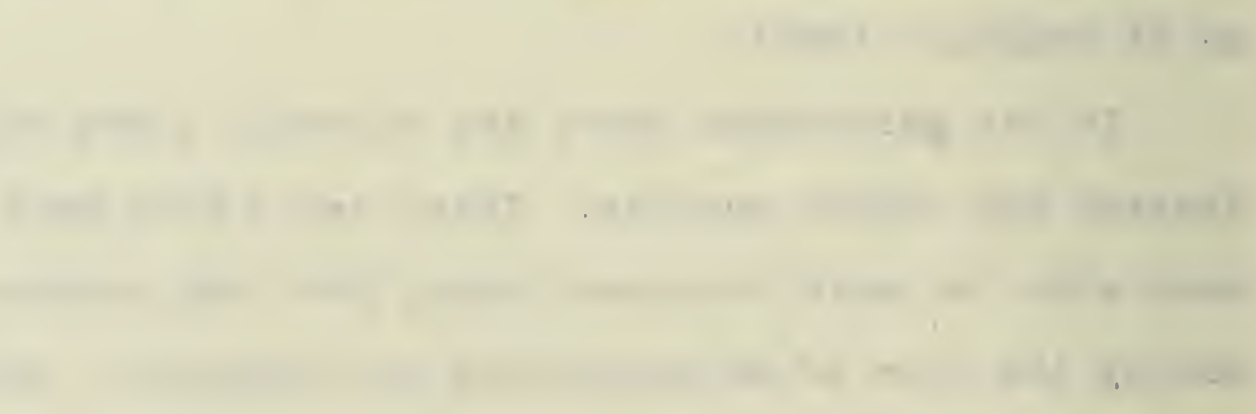

$\cdot$ 


\section{$-58-$}

In the form I have studied the aubcuticular dells come next to the longitudinal muscles in the parenchyma. They are not arranged in a regular manner but are in a specific layer which eren in the totomounts the subcuticular cell layer is well marked out. These cells have nuclei very much resembling the parenchyma cell nuclei but it seems to me this cell has a glandular nature rather than that of connective tissue structure gining use to parenchyma cells. Pratt (1909) thinks these colls have no ducts but are anastomosing branches which are interpreted as ducte. In my form I have seen very many spindle spaped cells their narrow ends toward the cuticula with a main branch which extends to the cuticula. Whether these branches ace ducts or ndt I cannot definitely say, but I am inclind to think that they are, as these branches are continuations from the cell which in some cases clearly can be seen. But if these dells are glandular, what is thoir function? Do they secret the cuticula as Blochman and othors think? Pratt's arguments against that view dno conclusite onough. Cuticula is found in every parasitic form but some ectoparasites have not the subouticular glands. As there is no definite experimental evidence to prove the nature of these cells there is need of such work to prove their nature. They might seeret oome kind of enzyme to assist the cuticula in counterating the injurious substances existing in the host body.

Musculature - The muscles are fairly well developed. Eapec ially the muscles of the oral sucker and acetabulum. The pharynx muscles are not as many as tho sucker muscles. The suckers and the pharynx have three kinds of muscles; radial, circular and meridianal or longitudinal, the radial muscles are the strongest. 


\section{- 59 -}

In the body there is another additional kind of muscle the diagonal muscles passing from the right to the left or reterse. The muscles consist of bundes of very fine fibers in intimate antact with each other. In a sagittal section; the circular musoles are next to the basement membrane in a regular rectangular block. In cross sections these are hemispherical. Next to the circular muscles comes the longitudinal muscles. Tho dagonal muscles can be seen in the parenchuma and are much finer. The heaviest radial muscles pass dorso-ventrally. There can be seen in cross sections muscles extending frov the aostabulum to the circular muscles called anchor muscles. The genital pore, the excretory pore and the oesophagus are ourrounded by carcular and longltudinal muscles.

The nervous system - The nervous syatom in this form io poorly developed. There is a central nervous eystem immediately posterior to the pharynx. It io composed of two ganglia on each side of the anterior end of the oesophagus united by a transversec cpmmissure dorsally to the oesophagus. There are three branches running anteriorly, the inner dorsalk a median, and a vontral one to the oral sucker, an exterior and a lateral. Three nerves run backward from each ganglion, dorsal, ventral and lateral.

I have not been able to work out the complete nervous system but it seems it does not differ from other species of this genus. 

DISCUSSION.

Diagnosis as given by Leiper (1915:573-575)

These worms resemble 0 . felineus but differ in the following points of specific importance. The skin is covered with minute acicuiar spinelets. The ovary is multilobate. The branches of the gut proceed almost to the extreme posterior end of the body. The ovary and the testes fill the last fourth of the body between the gut branches. The length of the orsophagus is from two to three times that of the pharynx, varying with the degree of contraction of the specimens. The ventral sucker is about equal in size to the oral, if anything occasioally alightly larger.

Hoat - Indian civit cat, and man.

"In Dr. Kerr's consignment of parasites obtained from prisoners in the Chiengmal jail was a tube containing three flukes regarding which the following notes were supplied" "Opisthorchis felineus? Ova found in about fifteen percent of the faeces examined, The worms were twice obtaind post mortem, in one case a single one from the intestine in another twelve worms from the gall bladder and large blle ducts. The ova have a small projection at the distal end, the cap. The worms also differ from the figures a have of 0 . felineus in having much larger part of the intestine unbranched, they also seem smaller, I was present at a post mortem by Dr. Mason where thousands of these worms were removed frorn the liver."

From the above quotation and the previous diagnosis of the form by Leiper who geems to have labeled the identificatonof the form as 0 . viverrini. My observations somewhat more in detail confirms Leiper's view. The form described in previous pages 



\section{$-61-$}

corresponds to that of 0 . viverrini. A comparative atudy of 0 . felindus and 0 . viverrini will confirm this view.

0 . felineus is much larger than 0.viverrini; the former being from 8 to $13 \mathrm{~mm}$ the later $6 \mathrm{~mm}$. The form in question is 2.7 to $7.7 \mathrm{~mm}$ an average of $5.3 \mathrm{~mm}$, corresponding to the later one as the $2 . ?$ forms were very much contracted very many of the forms measured from 5 to $6 \mathrm{~mm}$. The size of a form is a specific character. The view that the size of a parasite has variations with the size of the host is not accepted by prominent parasitolog18ts. Looss, Braun and others. L008s (1907:42) sigainst the view of Katsurado stated that every species of parasite has a gize of its own. The occasional variation above normal is a case just as is found in the higher animals.

The next most otriking difference between 0. felineus and 0 . vuverrini is in the size and shape of the ovary. In 0. Solineus the ovary is small simple or slightly lobed in 0 . viverrin i it is larger and always lobed in the form under diecussion. Phe seminal receptaculum in $O$. felineus is much larger comparda to the ovary than in 0 . viverrial. The recepteculum seminis is loss prominent than is 0 . felineus and relatively smaller than the ovary. Leiper in his paper reporta the skin covered with minute acicular spinelets; although I have examined numerous specimens both toto mounts and sections, I have not been able to see any spines. I have noticed in the outicula, or integument of some authors, deeply staining strands which might be looked upon as small spinelets but more careful study of a marginal sagittal section shows it to be of the same material as the walls of the parenchyma that is of connective tissue. 



\section{$-62-$}

In 0 . viverrini Poirier the suckers are small and equalo.28 nm in the vart Chiongmai nearly same as the above 0.19 by 0.224 $\mathrm{mm}$ the oral and 0.226 by $0.23 \mathrm{~mm}$ the ventral on the other hand 0. felineus has 0.25 to $0.28 \mathrm{~mm}$ the oral sucker width and $0.228 \mathrm{~mm}$ the length, the acetabulum 0.247 to $0.228 \mathrm{~mm}$ long and 0.197 to $0.228 \mathrm{~min}$ wide. The pharynx in 0 . folineus 0.204 to $0.169 \mathrm{bg}$ $0.160 \mathrm{~mm}$ to $0.170 \mathrm{~mm}$ in 0 . viverrini 0.14 by $0.13 \mathrm{~mm}$ varying from 0.13 to $0.18 \mathrm{~mm}$ in length and width $0.13 \mathrm{~mm}$ constant. Another marked difference between 0 , felineus and the two kinds of 0. Viverrini is the selature length of the oesophagus. In 0 . felineus it is very short nearly the size of the pharynx but in both varietise of 0 . Viverrini the oesophagus is about three times as long as the pharynx.

The uterine coils in felineus are more corpact and the coils do not correspond to that of 0. viverrin1. But one of the greatest evidences of these forms in wuestion not being an 0 . felinous is in the difference of the eggs of the two forms. The two 0 . viverrini are exactly alike, though my average estimate for the 0 . viverrini are exactly alike, though my average eatimate for the 0 . viverrini var. Chiengmai is a little greater than that given by Poirier. Polrier's form has a size 0.026 by $0.13 \mathrm{~mm}$ mine 0.026 by $0.0156 \mathrm{~mm}$. Minimum s1ze being $0.013 \mathrm{~mm}$ In 0. felineus the egg length varies 0.026 to $0.030 \mathrm{~mm}$ and the width 0.011 to the $0.015 \mathrm{~mm}$ with an average of 0.030 by $0.011 \mathrm{~mm}$ That is in 0 . felineus the egga are elongated and narrower, they have smooth outer operculum with the shell, but in both 0 . viverini the shell at the operculum takes a flask neck appearance insterd of a smooth round ending as in 0 . felinous. 

In 0 . felineus the exoretory system is $Y$-shaped in 0 . vivorrini Poirier not described but from the picture it is most likely aimilar to the new variety, which is stgmold. The primary ducts arising from different levels as represented in those figured.

Contrary to Looss's (1907:147) statement regarding the excretory bladder in the genus OPlsthorchis being $\mathbf{Y}$-shaped as one of the differentiating characters of Clonorchis from Opisthorchis the exoretory bladder in this form is like that of clonorchis.

Having in mind the different preserving methods and change in size of the forms accordingly in certain limits at certain parts expecially I conclude that the difference between 0 . felineus and this form is distinct enough not to diagnose it as a new variety of 0 . felineus but one of 0 . viverrint Poirier. Some of the characters described above are constent enough to be regarded as specific pecularities. Het as Braun, Lhe, Muhling, and Looss when studying the forms of the genus opisthorchis have spoken of the difficulty of distinguishing these species from each olther, the ame can be sald for this new variety. In anatomical detail, the topography of 0 . felineus and this form have very much in common. In fact these forms have acicular spino lets as Leiper seems to have seen one cannot say it is not 0 . viverrini as Poirier in his description does not give any detail in regard to that. Yet there stands a fact which might keep tho identity of these forms. Two forms might have identical features but by different spedies on biological ground, that is in the relation of the parasite to the host(Looss 1907:138). Te know that 0 . felineus inhabits the cat, dog, glutton, fox and man 



\section{$-64-$}

but 0 . viverrini has not been reported before, as being a normal parasite of man. Poirier found the form from Felix viverinius in France if the form found from siam in identical to that found by him we might expect human ingection of the same kind in France which ia not the case. The poseible explanation in this case would have been simple if we could trace the history of the cat. But as no one has reported O.viverrini ater. that we might assume that it was an isolated case probably brought from other region. Supposing such an introduction from India suggests that there must be cases in whlch dogs and cats in India are infected which until now has not been reported as far as I am ablo to ascertain. There 18 no doubt from the circumstances inwhich these forms were secured that these are normal hurnan parasites. But the similarity of the forms with 0 . viverrini Poirier and the possible case of being a rormal parasite in cats too gives some cortainty of its identity with 0 . viverrini Poirier. Thru the kimdness of Dr. H. B. Ward I examined some of his collection of 0 . Lelineus. One form from the liver of man collected by Dr. Askanszy at Geneve, the other from St. Petersburg extracted by Kowalewary from the cat. The two forms have some miner variation The form living in rman is much closer to the form in question than that from the cat, the oides run parallel and greateat width $1.1 \mathrm{~mm}$ but the form from the cat was much broader $2.9 \mathrm{~mm}$. The oesophagus length $0.28 \mathrm{~mm}$ in the firet olre and only $0.228 \mathrm{~mm}$ in the latter. From this comparison I can see the explanation of the olight differences found between that of Poirier and mine. From Poirier'a figure the form has not parallel oides but tapering at the anterior end gradually widening till the posterior end 

which narrows and ends as in the variety described. In the figure given by Poirier the genital pore is placed much farther above the acetabulum than in forms I have examined. In his description Poirier states that the genital pore lies immediately anterior to the acetabulum to I regard the representation in the figure much farther than in fact it is. The posterior testis is described and figured as four lobed, but as Poirier does not mention how many forms he has examined I am inclined to thiak in the normal case it has five. From 50 individuals examined espec ially for this difforence I found five with four lobes in many cases one the lobes poorly developed. The position of the genital pore 18 constant and is specific but not the lobes of the testis. In the typical fonms the anterior is four and the posterior five lobes but this varies within certain limits. In Leiper's figure the lobes in the posterior testis are much deeper than those I find in any on of my specimens otherwise the form is similar to mine except in none of the forms I have atudied do I find any spines as Leiper stated to have found in his.

I add a few more records which might be of significance to explat the possible occurance of 0 . viverrini in man.

In 1907 Verdun and Bruyant recorded the occurance of 0. felinoug in a patient from Hanot. The okin is stated to be smooth and the ovary round or arcuate. Mamell gent from Formosa a macerated specimen from the atool of a cat to Leiper which had short spines on the cutlcula. As the testes were digested it could not be decided whether it is an opisthorchis or clonorchis Looss $(1907: 152)$ reports a form sent to him by Chun which was 
poorly preserved and could not be identified. But the form was $4.5 \mathrm{~mm}$ in length $0.9 \mathrm{~mm}$ in breadth. He calls attention to a report from Ijima in 1886 which atates that the ame kind of forms naving short spined in the skin were taken from the liver of a cat. This form was regarded as a different form of clonorchis endemicus. Accordingly Looss seid it might be another species. Lelper thinks it might be 0 . viverrini variety in question. One thing definite is tha that 0 . viverrini poirier is identical w th the form in question and anatomically bas very close resemblances to 0 . felineus. From a blological standpoint there is more definite proof this boing a variety of 0 . felineus which is a normal parasite of man and also of the cat, that 0 . viverrini Polrier, which is reported definitely only from the cet. If it can be proven that 0 . viverrini var. Chiengmai in not parasitic in the cat then it will become a new species instead of a variety of 0 . viverrini. But from the data at hand I cen with a certain degree of certainty say that this form is opisthorchis viverrini.

But this only posaible reasoning is less important if we bear in mind that Feline Opisthorchis may occassionally occur in man as stated by Looss (1907:152). Not only is this true in the case fo Opisthorchis bit in other forms as Paragonimus westermand and kellicottl anre found both in the dog and in man, in Japan. Certain canine and feline parasites as Coccicium bigeminum, Ascaris, Dipylidium are parasites in man also. Therefore I dagnose this form as 0 . viverrini Polrier var. Chiengmai, a normal paraaite fo the Indian civet cat not recordod heretofore from man. In finjshing I would expeess my thanks to Professor H. B. Fard for his valuable suggestions during this work. 

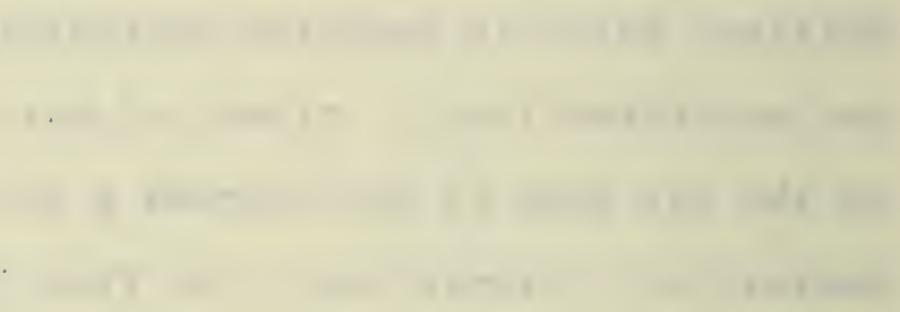


\section{SUMBARY}

1. The history of the genue Opisthorchis is given.

2. Specific dagnosis of the forms belonging to the genera Opistiorchis, Amphimerus and Paropisthorchis is given with their generic diagnosis.

83 . The relation of the species, the difficulty of their identification is discussed briefly.

4. The description of a human parasite belonging to the genus opisthorchis is worked somewhat in detail and diagnosed as opisthorchis viverrini., var. Chiengrai. 



\section{LITERATUKE}

\section{Askanazy, Max}

1900 Ueber Infektion des Menschen mit Distom felineum (Sibiricum) in Ostproussen und ihren zusammenhang mit Legerkrebs. Ctrbl Eakt. Paras. 1, 38: 491-502.

1900 a $\mathrm{D}$ stomum felineum in Ostpreussen beim Menschen. Ctrbl. allg. Path. Path. Anat, 11:711-712.

1904 Die Aetiology und pathologje der Katzenegelerkrankung des Menschen. Deutsch. Med. Wochenschr. $30: 689-691$

$$
\text { (0.) felineus) }
$$

1906. Weitere Mitteilungen ther die quelie der Infektion mit Distomum felinuem. Schrift. Phys. Okon. Ges. Konigsberg, 46:127-131.

$$
\text { (0. folineus) }
$$

Blanchard, $R$.

1895 Animaux parasites. Bull Soc. 2001. France 20:217 (Opisthorchis

1895a Maladies parasitameo, parasites animaux, parasites vegtaux a l'exclusion des Bacteries. Traite de pathol. gen. de ch. Bouchard 8:649 -932 (Opiathorchis)

1895b Notices sur les parasites de I'homme. Ctrbl. Bakt. L. Paras. 1, $17: 2-13$.

$1900 \mathrm{Du}$ role des ceux et des legumes dans l'etiologio de l'helmanthiase intestinale. Arch Paras. 


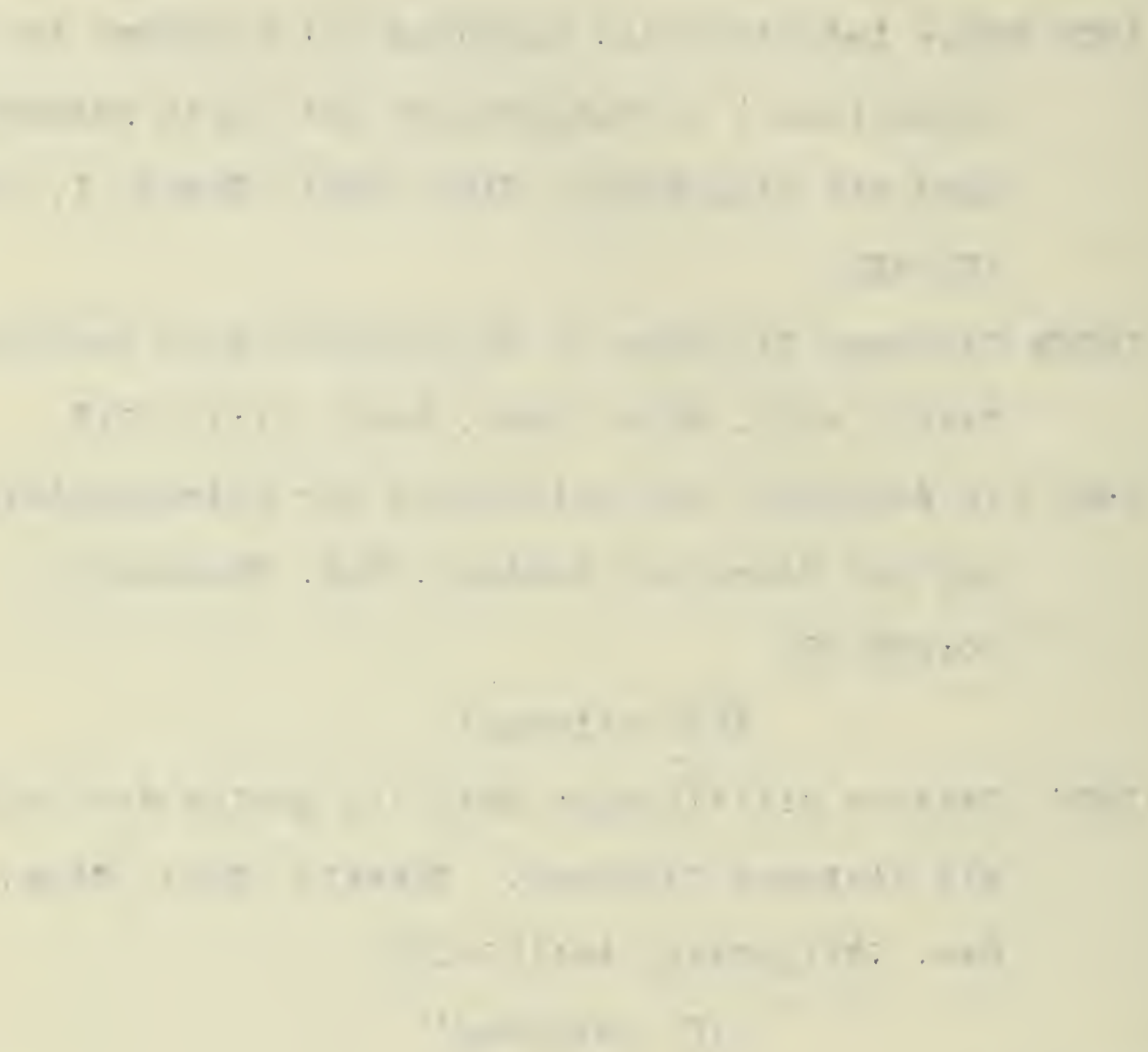


$3: 485-491$

(0. felineus)

Bossuat, Emile.

1902. Les helminthes dans le foie. Arch. parasit. $5: 161-206$.

\section{(0. felineus)}

Braun, Max.

1893. Uber die Distomum in der Leber der Haukatzen. 2001. Anz. 16:34:7-355.

(0. felineus)

1893. a Die Leberdiatomon der Hauskatze (Felis catue domesticus und verwandeArter) Ctrbl. Bakt. L. Baras. 1, $14: 381-392,422-428$.

(0. felineus)

1894. Distomum sibiricum. 8001. Anz. 17:128-129

1894a. Uber ein fur den Menschen neues Distomum aus der Lebor. Ctrbl. Bakt. u. Paras. 1, ;5: 602-606. (0. felineus)

1900. Ueber Campula oblonga Cobb. Ctrbl.Bakt. u. Paras. $1,28: 8-9,249-252$.

1901. Trematoden der Chelonier Mitt a, d. Zool. Mus. Ber1., 2:34.

$$
\text { (0. sinensis, 0. geminus) }
$$

1901a. Zur Revieion der Trematoden der Vogel. CtrbI. Bakt. Paras. 1, 29:560-568.

1902. Fascloliden der V8gel. Z001. Jahrb. Syst. 16:5-6 (0. Interruptus, 0. Iancea, opisth.)

1908. Die tierischen parasiten des Menschen. Ed.4 : 186-190 (0. fel., 0.nov., 0.pseudo.) 

Ciurea,

1914. Recherches Sur la Source de l'infectionde I'homme et des animauz par les distomes de la famille des Opisthorchiles. Buld. Bect. Sient. Acad Roumaine Ann. 21:201-205

Cobbard, T: S.

1859. Synopola of the Distomidae. Journ. Lenn. Soc. London, 2001. 5:1-56.

$$
\text { (0.nov.F D. conjunctum) }
$$

1861. Further observation on entozoa with experimento. Trang. Lian. Soo. Lonàon. 23:349.

$$
(0 \cdot \text { nov }=D \cdot \text { conjuntum) }
$$

Cholodkoveky, N.

1897. Distomum felinoum in der Leber des Menschen.

Trav. Soc. Nat. St. Petersburg. 27:185-186.

$$
\text { (c. folineus) }
$$

1898. Icones helminthum hominis. 2 st. Petersburg.

$$
\text { (0. felineus) }
$$

1898a. Sur quelques rares parasites de lokomme en Kusato. Arch. Parasit. 1:354-355.

$$
\text { (0.felineus) }
$$

Diesing, K. M.

1850. Syatema helminthum $1: 334$

$$
\text { (0. Iances) }
$$

Engler, Kurt.

1904. Abnormer Darmverlauf bel 0. felineus. Zool. Anz. $28: 186-188$. 

Galli-Valeria, Bruno.

1898. O. piana Nov. sp. eine veue Distomidenart der Wildente. Ctrbl. Bakt. 1;23:145-146.

1898a. Ueber Opiathorchio pianae H.ap. Eine Erwioderung an Herrn Prof. M. Kowalewski. Ctrbl. Bakt. u. Paras. 1, 24: 923.

$1898 \mathrm{~b} .0$. planae nov sp. eine neue Distomidenart der Wildente. CtrbI. Rakt. 1,23:145-146.

1901. La collection de parasites du laboratolre d'hygiene t de parasitologie de l'universite de Lausanne. Bull. Soc Vandoise d. 8c. Nat., Lausanne 37:364. (0. felineus)

Guerrini - Guido. - .

1913. Ueber einen bia jetzt mbekannten fall parasitarer infektion ( 0 . felineus) in der Leber eines Kaniachens). Zeitschr. Infectionskrankl. paras. Krankh. Hyg. Haustiere. 64:262-270.

Gurlt, E. F.

1831. Lehrbuch der petholog1schen Anatomie der HausStugethiere 1:373-375.

$$
\text { (o. feleneus) }
$$

Hymann, George.

1905. Neue Distomen aus Cheloniern. 2001. Jahrb., Syst. $22: 38$.

(Ogisthorchis)

Hallack, Johanne.

1902. Zur Konntnks der sexuellen Amphitypie bei Deorocoelifinen, Ctrbl. Bakt. 1,32:867-869.

(0. fel., 0.epec.) 

Jacoby, Severia.

1900. Beitrlge zur Kenntnio einiger Distomen. Arch. Naturg . 66:1-30.

$$
\text { (0.fel. D. ten.) }
$$

deLONB, D. A.

1887. Distomum campanulatum en Distomum felinoum bij. den Hond. Tijdachr.v. vieartsenihk. on verteilt. Utrecht 14: 57-62.

$$
\text { (0. 801.) }
$$

1896 Leverdiatomen bij Hond en Kat. Tijdach. v. viecetsenijk on verteelt. Utrecht $24: 1-12$.

Kamensky, G.

1900. Sur I'opisthorchis tenuicolles (Rud. MthI) = D. felineum Fiv.

Kowalewaki, M.

1898. Uber Opisthorchis pianae Galli-Valerio. Ctrbl. Bakt. 1, 23:751-752.

$1898 \mathrm{a}$ Etudeshelminthologiques v.contribution a 18 tude de quelques Tremetodes. Bull. Intern. Acad. Sc. Cracovie, 69-77.

$$
(0 . \text { long,. } 0 . \sin , 0 . \operatorname{ten} .)
$$

1902. (Material for poliah helminthological parasitic funa III. Sprawoz. Kom. fizyogr. Akad. Umiej. W. Krakow. 35:21-30. (0. sin) Abotract by Max Braun in 2001 Ctrbl 9:837.

Lewis, T. R. and Cunningham, $D$.

1871. Mioroscopical and physiological researches into the Nature of the agent or agents prodming chol- 

era. 8th Ann. Roport Lan Cam. Gov. India for 1871. Calcu ta 1872, p.168,

ID. conjunctim = Paropisthorchis caninut

Leiper, R. T.

Opisthorchis viverrini, recorded from man in Siam. Boy. Army Med. C. 241-573.

Linstow, 0 . van.

1883. Nematoden, Trematoden und Acanthocephalen, gesammelt mon Prof. Fed tschenko in Turkestan. Arch. Naturg. Jahrg. 49, 1, 274-314.

$$
\text { (0. long.) }
$$

LOOBB, A.

1896. Recherches Sur Ia faune parasitalre de L8Egypte premiere partie. Mem. de I'Inst. Egypt. 3:50-52.

$$
\text { (0. gem., 0. sin.) }
$$

1899. Weitere Beitrage zur Kenntness der Trematoden Fauna Aegyptens. Z001. Jahrb. Syst. 12:521-784. (D. sin. O.ten. 0. long. 0. spec.)

1901. Zur sammel und Conserverungstechnik von Helminthen. 2001. Anz. 24:309-318.

1905. Ven Wurmern und Arthropoden hervorgerufene Erkrankungen. Handb. d. Tropenkrankh. Leipz.1: 89.

$$
\text { (0. fel.) }
$$

1907. On some parasites in the Museum of the School of Tropical medicine, Ltverpool. Anrals. Trop. Med. Parasit 1:138-139.

(Opisthorchis, Clonorchis) 

Lthe, Nax.

1899. Zur Kenntnis einiger Distomen. Z001. Anz. 22: $524-539$.

(Opisthorchis)

1901. Uber Hermiuriden. Z00I Anz. 24:473-488.

(Opisthorchis)

1909. Zur Systemstik und Faunistik der Distomen. 1.

De Gattung Metorchis Looss. nebst Bermerkungen uber die Familie Poisthorchildae. Ctrbl. Bakt. $1,48: 428$.

Mc Conneli, J. F. P.

1876. On the "Distoma conjunotum" as a Heman entozooz. Lancet $1: 342-344$

$$
\text { (0. nov.) }
$$

Monticelii, F. S.

Di um ematozoe della Thalassochelys curetta Lenn Internal, Monatachr. f. Anat. u. Physiol. 13: $141-172$.

(Opisthorchis)

Mhling, Paul.

1896 Beitrage zur Kenntniss der Trematoden. Arch. Naturg., Jahrg. 62: 243-279. (0. ten., 0.fel., 0. exudo.)

1898. Die Helminthen Fauna der wirbeltiere Ostpreusens Arch. Naturg., 1, $64: 24$.

$$
\text { (0. ten.) }
$$

Nicoll, William.

1914. The Trematode parasites of North Queensland II 


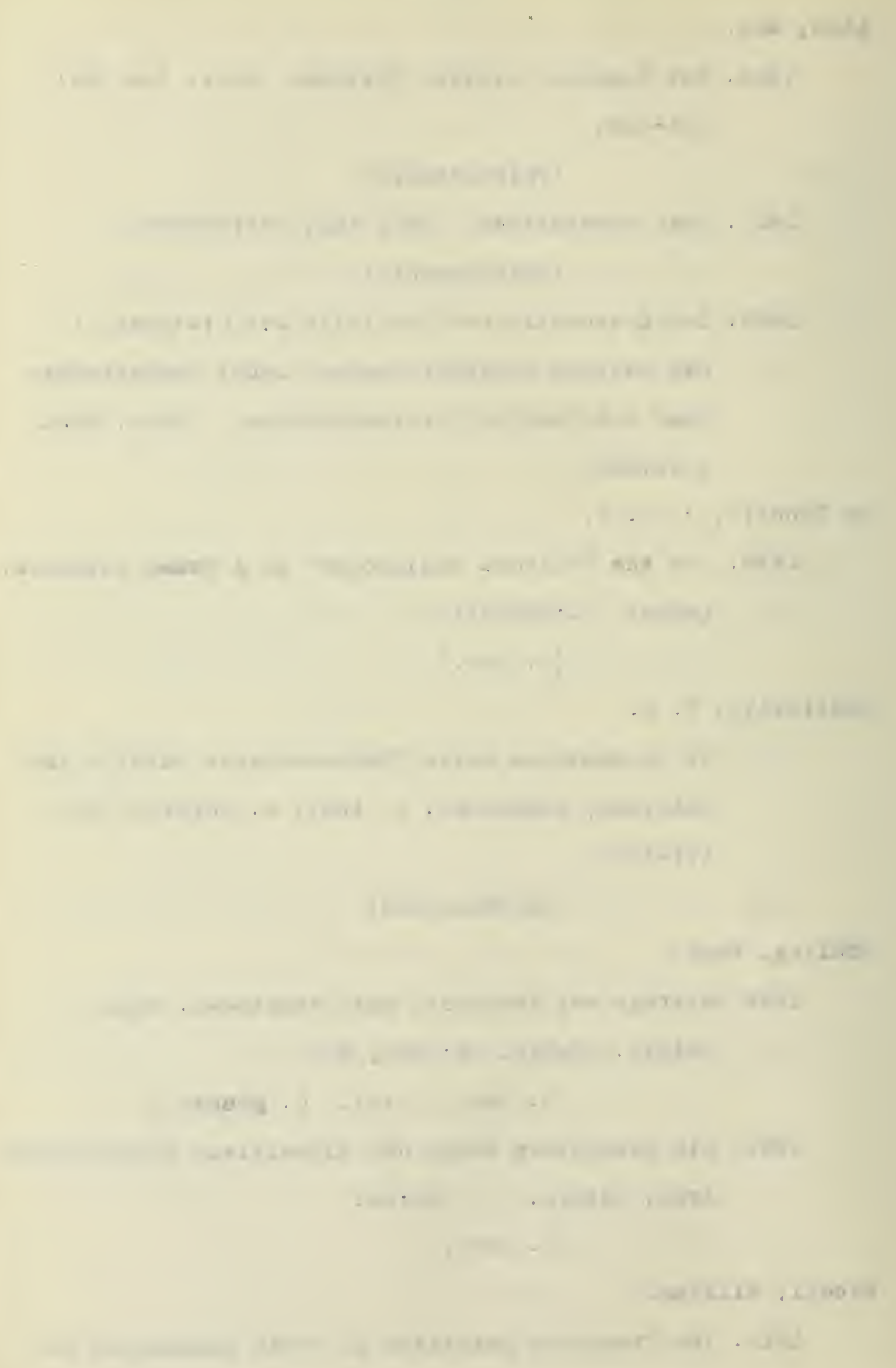


Barastes of Bira. Parait. 7:105-126.

(0. obsequens, ).

Ofenheim, Ernest van.

1900. Ueber eine neue Bistomengattung. Ztachr. Naturw.

73: 166 .

(Opisthorchis)

Odhner, Theodor.

1802. Mitteilungen zur Kenntnis der Distomen II.

CtrbI Bakt. 1, 31:15a-153.

(0. piscicola)

1905. Die Trematoden des artischen Gebietes in Rome and Schaudinn. Gauna Arctica 4: 291-372.

(0. tenuicol118)

Poirier, T.

1887. Trematodes nouveaus ou peu connus. BuIl Soc. Philomat. paris. 10: 20-41

(0. viv.)

Pratt, H. S.

1902. Synopeis of North American invertebrates.

Amer Naturlist $36: 887-900$.

(Opis thorchis)

Ratz, S. von.

1900. Parasitologiai jigyz1tek. Veterinarius, Budapest, 23: 532-534.

$$
(0 . e n t z i)(0 . t e n .)
$$

Rato, Istran.

1903. It eskeversi lsmet bazai metehyek. Allatt Kozlem K०จ. 2:83-88.

(0. entzi) 

Railizet, A.

1896. Quelque rectifications a 12 momenclature des parasites. Rec. de. Med. Vet. Paris. 2: 157-161.

(Opiathorchis)

Rivolta, S.

1884. Sopra una specie di Distoma nel Gatto e nel cano. Giornale di anat firiol. patol. di animali. 15: $20-29$.

$$
\text { (0. fel.) }
$$

Rudolphi, C. A.

1819. Entozoorum Synopsis p 93 et 355 .

$$
\text { (0. ten.) }
$$

Roth, C. A.

1904. Beitrge sur Kenntnts der parasiteren. Eischkrankheiten. Vo. Die plotze (Louciscus rutilus) als veranlassung zur Entstehung des Leber grebses beim Menschen Natur. u. Hans. 13:93-94.

$$
\text { (0. fel.) }
$$

Stephens., Exntham and Theobald.

1916. Animal parasites of man.

(O.fel. Parop. caninus, Amphi. noverca)

Siebold, C. TH. von.

1836. Helminth Beitrage 1I. Arch f. Naturg. 1:113.

$$
\text { (0. fel.) }
$$

Skrjabin, K. R.

1913. Vogel trematoden aus Russinch Turkeatan. Zoo1. Jahrb. Syst. 35:351-388.

(0. gem.) 

Stiles, Ch. W.

1901. A discuseion of certain questions of nomenclature a. spplied to parasites. Zool. Jahrb. Syst. 15: 203-205.

(Op16 thorchis)

1902. Two trematod8s (Monostomum Ientis and Heemodistomum Opthalmobium parasitio in the human eye. Bull 35, Bur. An. Indust. U. S. Dept. Agric. Wash. p. 53 .

$$
\text { (0. fel.) }
$$

1904. Illuatrated key to the trematode parasites of man. Bull 17, Hyg. Lab., U. S. Pub. Heal th and Mar. Hosp. Serv. Wash.

(0. fel., 0. pseud. 0. nov.)

Stiles, Ch, W. and Hassall, A.

No. 21. Beterin. Mag.1: 413-432.

(0. ten. 0.viv. 0.fel. 0.epec. 0.10ng.)

1896. Notes on parasites No. 42. Veterin Mag. 3:151-155

$$
\text { (0. Iong. 0. spec. 0. viv. 0. ten.) }
$$

1898. An inventory of the genere and the subgenera of the Trenadode family Fasciolidae. Arch Parasit. $1: 85-91$.

\section{(Opisthorchis)}

1908. Indes Catalog of Medical and Veterinary Zooloby. Subjects: Trematoda and Trematode Diseases. Bull 37 Hygienic Lab. U. S. Pub. Health and Mar. Hosp. Serv. Wash, p 33t-334. 

Stossich, M.

1904. Alcuni Distomi delli Collezione elmintologicadel museo Zoologico di Nepoli Ann. Mus. Zool. Univ. Naples. 1: 1-14.

(0. lenc. 0. leng., 0. spec., 0. nov. 0. pфsc., 0. sin. 0. ten. 0. inter.)

Verdun, P. and Bruyant, L.

7907. Existance de la Douve du chat(Opir. felineus Riv) au Tonkin Lon Association chez 1 'Homme, avec la Douve de chine (Clonorchis sinensis Cobb.)

C. R. SOc. Biol, $42: 7 \mathrm{C}^{4}$.

1908. La Douve du chat, Opisthorchis felineus (Riv.) Arch. Parasit. 12:125-134.

( o. fel. o. ten., 0.vtr. 0. gem. 0.sin.)

1908a. Sur 1a dualite opecifique de la Douve de chine. Clonorchis sinessis(Cobbold 1875) Arch parasit. $12: 123$.

$$
\text { ( } 0 . f \in 1.0 . g e m .)
$$

Ward, H. B.

1894. The parasitic worms of Man and the domestic Animals. Ann Rep Nobr. State Bull. Agz1. 225-348. (0. preud.)

1895. On Distomum folinoum in the United States and on the value of measurements in speoific Determination among Distomes. Veterin. Mag. 2:152-158 

6 $1895 a$ Helminthologisohe Not1zen $2 \mathrm{D}$. felineum Riv. in den vereinogten Staaten. Ctrbl Bakt. 1,17:304.

$$
\text { (0. pseud.) }
$$

1898 Parasites of Nebraska dogs and cats Univ. Mebr. Zool. Zool Lab Stud. 2: Ko. 26, 305.

$$
\text { (0. pseud.) }
$$

1901. Notes on the parasites of the Lake Fish. III Trans. Am. Mic. Soc. $12: 175-187$.

$$
\text { (0. fel. 0. preud.) }
$$

1903. Trematoda. Woods Ref. Handb. Med. Sco. revised ed. $6 \mathrm{p} 704$.

$$
\text { (0. fel. O. Mov.) }
$$

Weaki, Oakar.

1900. Mitte1lungen uber Distomum lancea Dies. Ctrbl. Bakt. 1, 27: 579- 583 .

$$
\text { (0. lanc.) }
$$

Winogradof $f, K$.

1892. Un nouveau Distome du fole de llHomme nouvelle de 1'Universite de Tomsk. 4: 166

$$
\text { (0. fel.) }
$$

$1893 a$ Un deuxieme das de Distomum sibiricum nouvelles de I'Rniveraite de Tomok 4:131.

$$
\text { (o. Gib. } 0 . \text { fel.) }
$$

1893. Ueber Whrmer, welche im menschlich nkorper parasi asitieren; nach den Ergebnissen der siktionen bel der Universitat. Tomsk Nachs. d.k. Tomskschen Univ. 1892. p 1-13.

$$
\text { (0. fel.) }
$$



Zwaademaker, H.

1890. Cirrhosis parasitaria. Arch path. Anat. 120:197203.

$$
\text { (o. fel.) }
$$



VII. EXPLANATION GF PLATES.

\section{Abbreviatione}

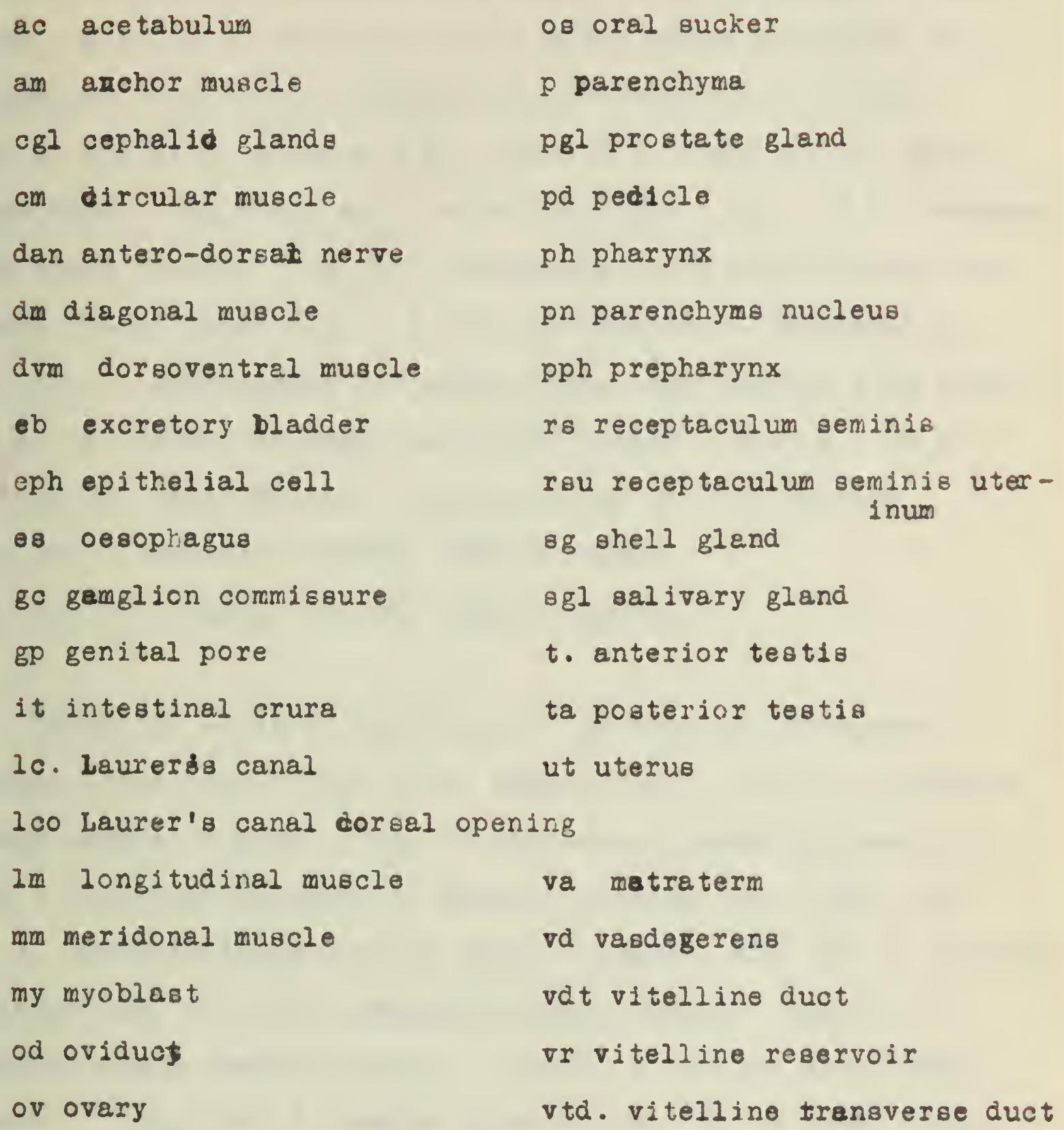

ac ace tabulurs

am archor muscle

cgl cephalid glands

cm dircular muscle

dan antero-dorsaz nerve

dm diagonal muscle

dvm dorsoventral muscle

eb excretory bladder

eph epithelial cell

es oesophagus

gc gamglion commisaure

gp genital pore

it intestinal crura

1c. Laurerso canal

1 co Laurer's canal dorsal opening

Im longitudinal muscle

mm meridonal muscle

my myoblast

od ovidue

ov ovary

os oral sucker

p parenchyma

pgl prostate gland

pd pedicle

ph pharynx

pn parenchyms nucleus

pph prepharynx

rs receptaculum seminis

rou receptaculun seminjs uter-

$8 g$ shell glend inum

agl salivary gland

t. anterior testis

ta posterior teatia

ut uterus 

PLATE I. - Fig. I Opisthorchid aibiricum( $=0$. felineus) magnified after Winogradoff from Braun. Fig. 2 Egg of 0 . felineus. Eig. 3. 0. felineus (Riv.) after Braun magnified. Fig. 4 0. geminus $\times 10.5$ Loose Plate $24 \mathrm{fig.2}$ From Aras penelope.

Fig. 5. Egg of 0 . geminus $x 631$. Eig. 60 . simulans $x 81$ after Loos 1899. Fig. Egg of 0. Bimulans x 631 Fig. 80 obsequess x 24 after Nicoll. Fig. 90 . tenuicollis xI5 efter Braun from Barker. (1911 pl $20 \mathrm{fig.4.)} \mathrm{Fig} 10 \mathrm{Egg}$ of 0 . tenuicoldio Fig. 11. 0. longisstmus $x I 0$ after Stiles and Hassall from Barker. Fig 12. 0. viverrini magnified after Leiper. Fig 13. 01 viv erini $\times 17$ after poirier. Fig. 14. Egg of 0 . viverrini Fig. 15. O viverrini central feile organs. Fig. 16. 0. simulans central female organs.

PlATE II. - Fig 17 Op18thorohis geminue XII from Anas boschar Loose 1899. Fig. 18 o. geminus egg. Fig 19. O geminus female central organs. Fig. 20 Amphimerus pseudofelineus $x 7$ ward (Reference handbook of medical Science Fig. 4778) Fig. 21. A. pseudofelineus Central female organs. Fig. 22. A. preudofelineus egg. Fig. 23 A. Pseudofelinews apines. Fig 24. A. pseudofelineus genital region. Fig 25. A. ovalia xl6.5 dfer Barker . Ftg. 26. A. ovalis spines. Eig. 27. A. ovelis egg. Fig. 28. A. ovalis genital region. Fig 29. A. lancea Diesing x17. ventral view after Weski. Fig. 30. A. spec1osus x15 After Stiles and Hassall from Barber. Eig. 31. A. opeciosus egg. F1g. 32\% A. interruptuð (from Aloedo bicolor) x20 After Braun. Hig. 33. A. noverce agter Leuokart, from Braun. Fig. 34. A. noverca egg. Fig. 35 Paropisthorchis caninus xl3 from Barker 

Fig. 36. P. caninus spines.

PLATE III. Fig 37-Opisthorohis viverrini, var. Chiengmai x37 ventral view. Fig 38. O. viverrini x30 dorsal view. Fig. 39. Female central organs xl35 dorsal view. Fig. 40 Female central organs $\times 135$ ventral view. Fig 41. Genital region $\times 100$ dorsal view. Fig 42. egge of 01 viverrini $\times 840$. Fig. 43. An egg of 0 viverrini $x 800$. Fig 44. A was model $x 50$ of the mare reproductive syetem. Fig. 45. From was model of genttal atrium. representidnthe opening of vas deferens and notreterm into the common atrium. Fig. 46. A cross section $\times 340$ representing the tall epltholial cells and ourrounding narrow olongated nucleated cel18.

PLATE IV. Fig. 47 A cross section of the acetabulum $\times 340$ the anchor, the radial meridional and circular muscles of the $s$ sucker represented. Fig. 48. A seggital section through the acetabulum representing the vas defenens and duotus ejaculatorus and muscles of the acetabulum. Fig. A saggital section thru the ovary and receptaculum seminis representing the dorsal opening of Laurer's canal the ootype in which open aingle irolated shell glands. Fig. 50. A oross seotion of acetabulum.

BuATE V. Fig. 51 A saggital section thru the oral sucker and the pharyns. x 100. Fig. 52. A cross section thru the pharyns x100. Rit 53. Cephalid glands $\times 840$. Fifg. 54. A cross section posterior to pharynx. Fig 55. Vitaline glanos in the parenchyms $x$ 840. Figl 56. A saggital section $x 340$ showing mulczoa. Fig. 57. The central nervous system $x$ 100. Fig 58. The excretory systom in part. 

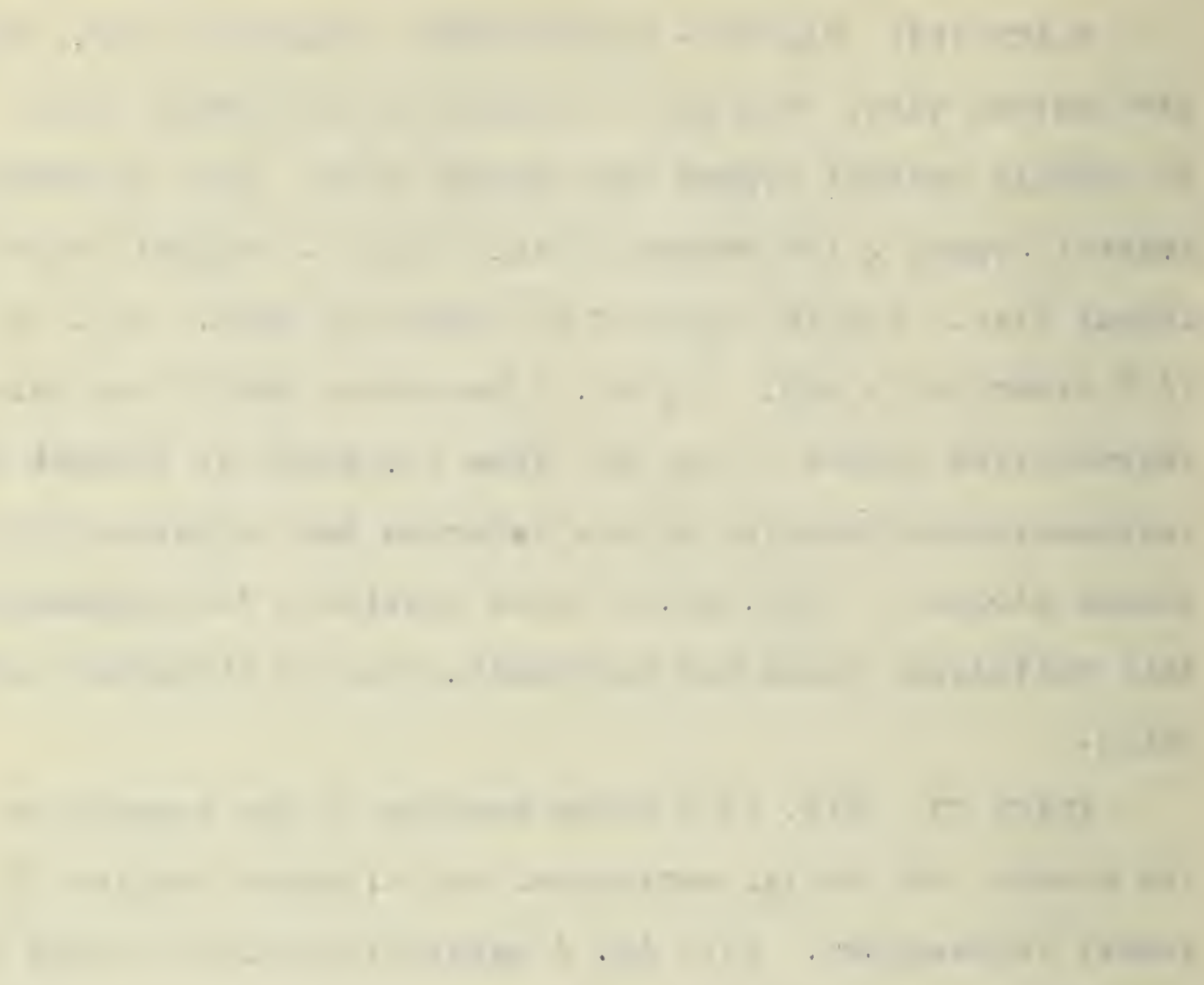


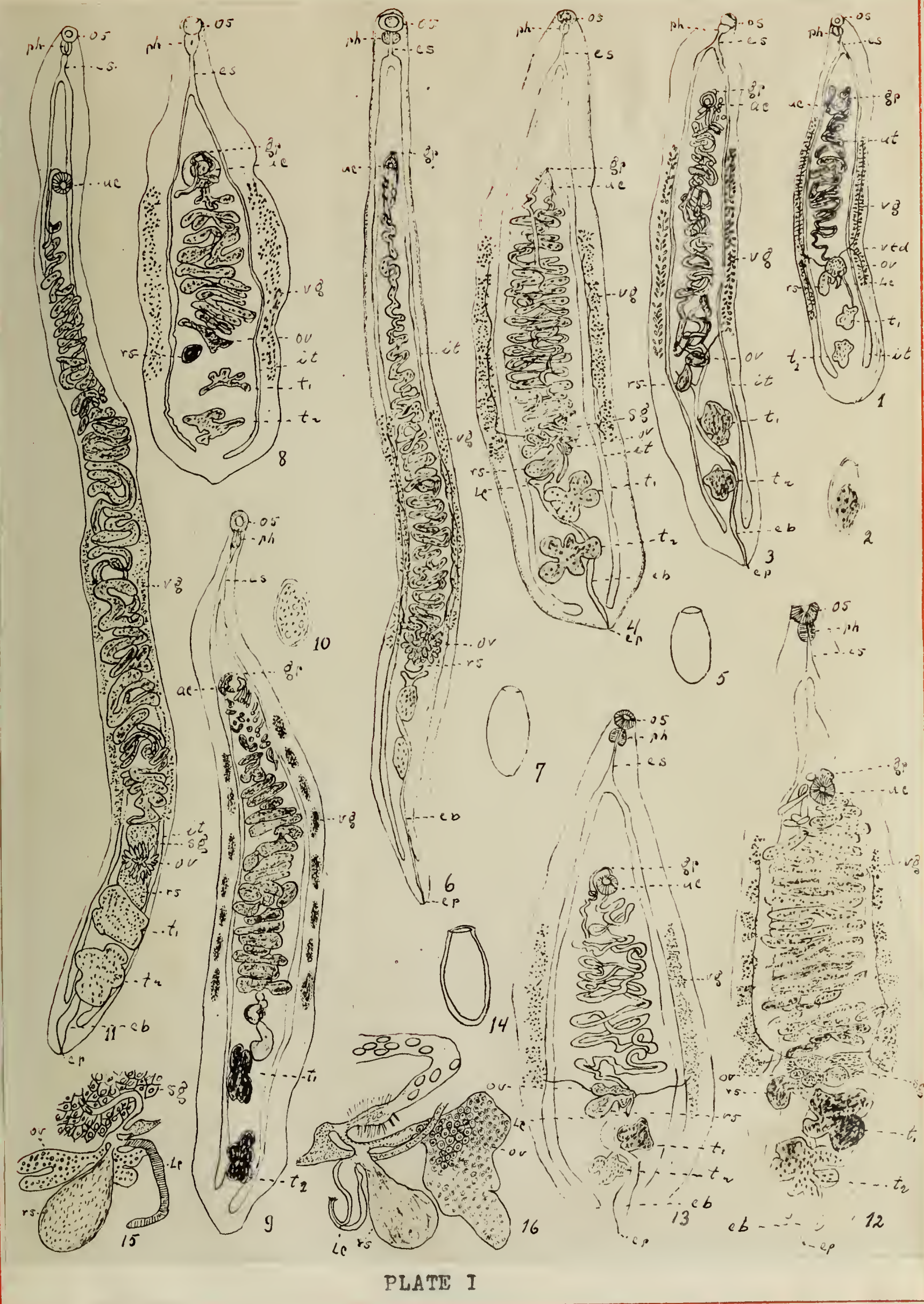




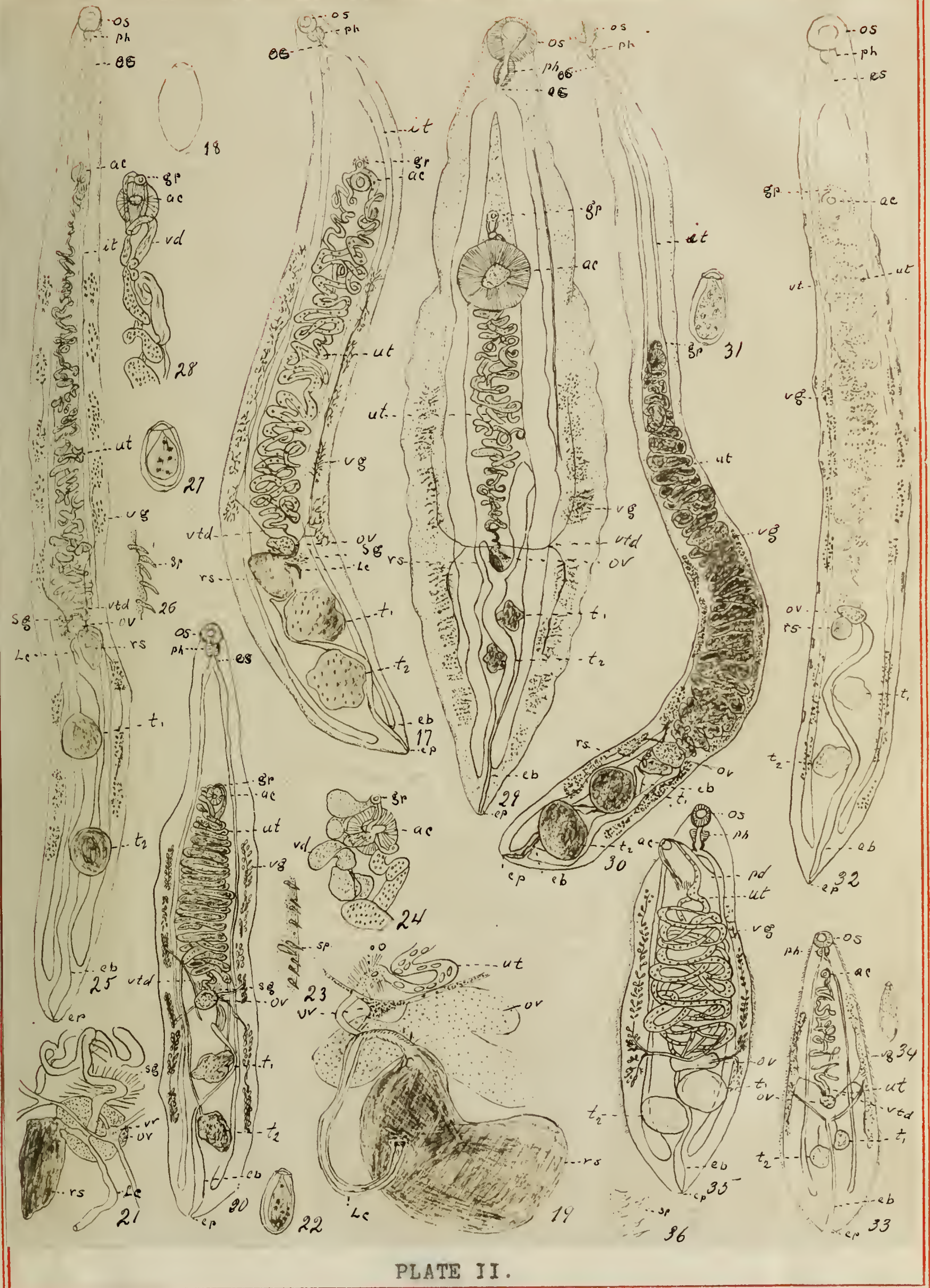




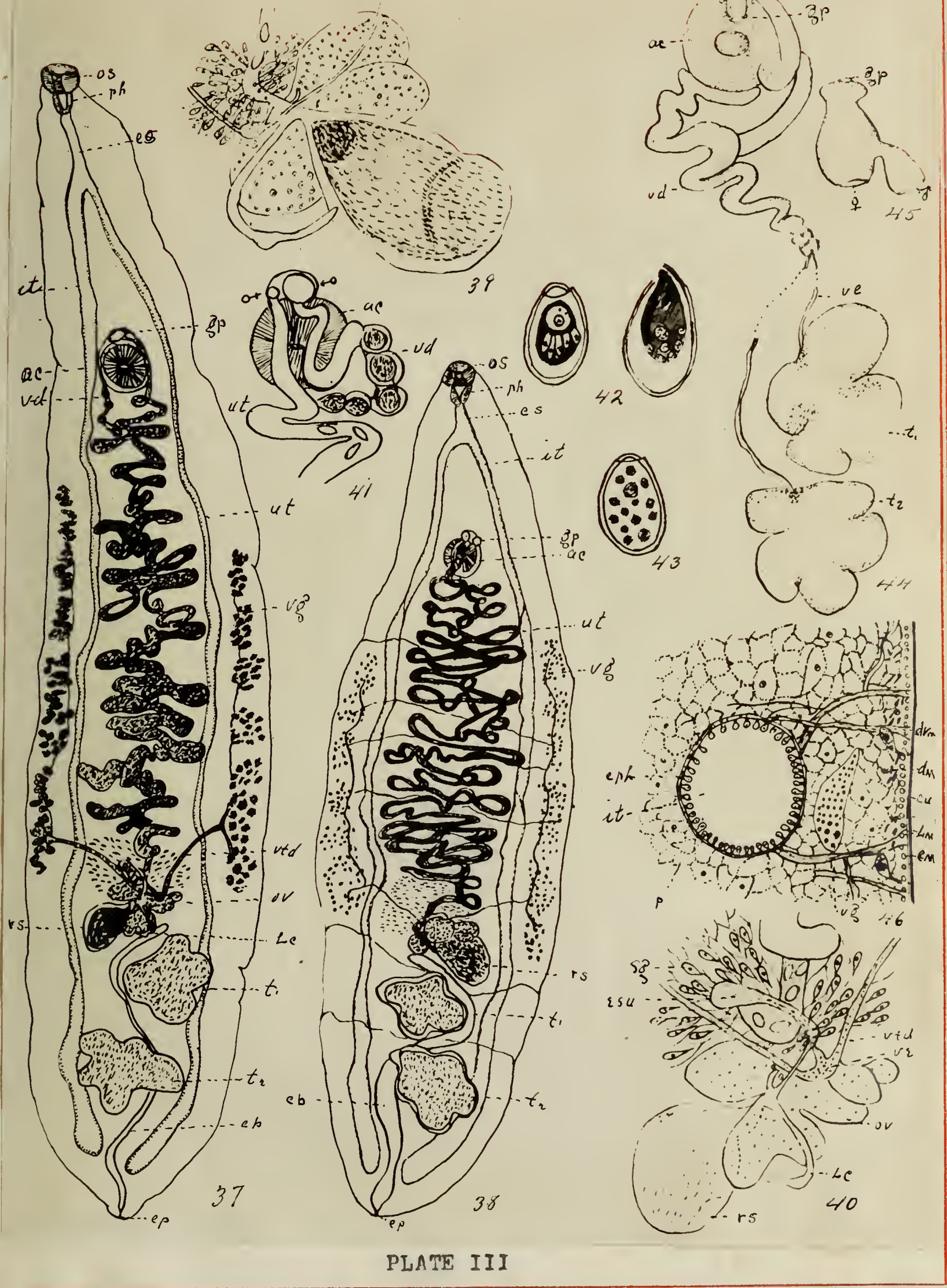





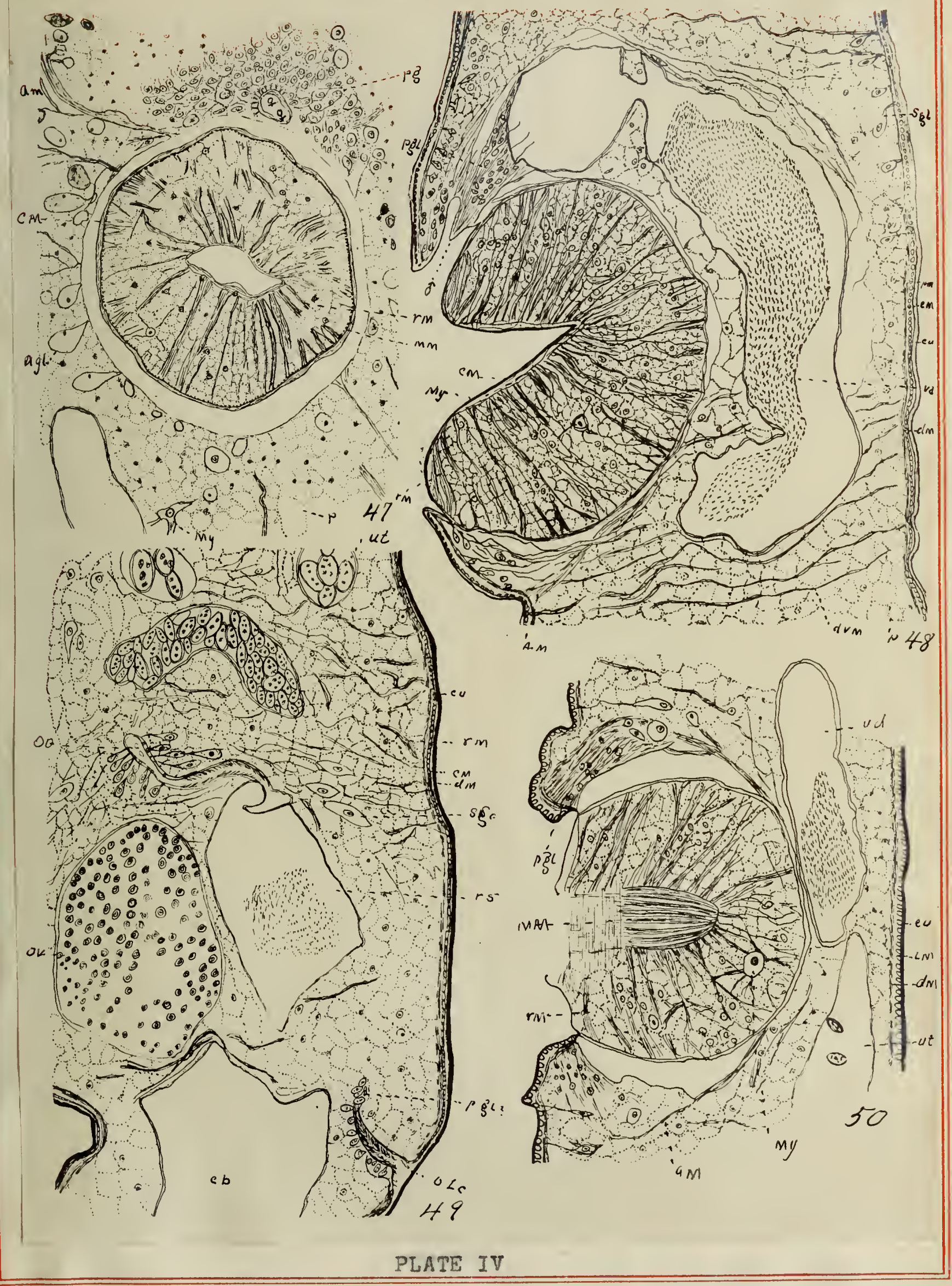





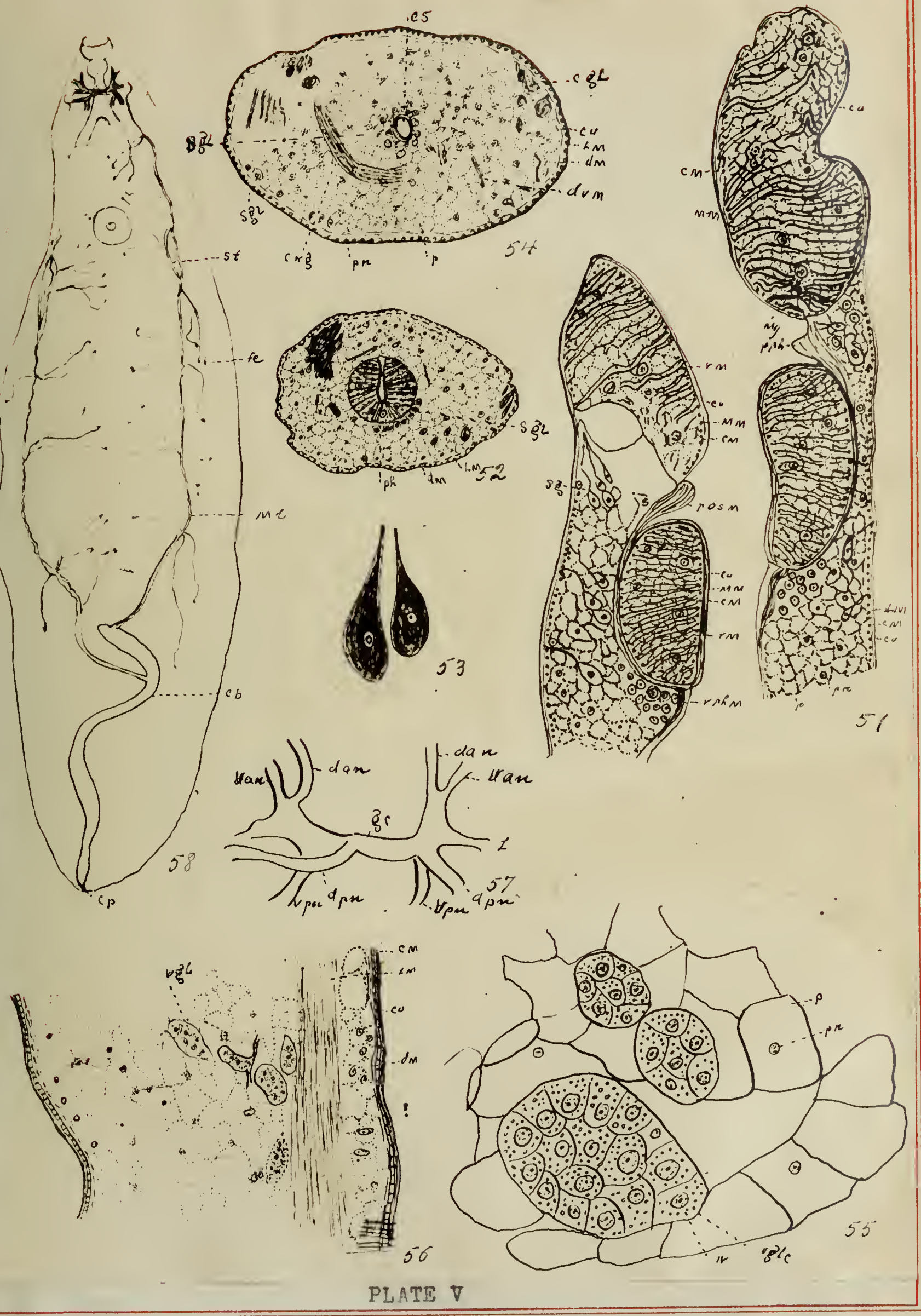




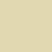


I.

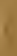


